\title{
Development of Backfill Material as an Engineered Barrier in the Waste Package System-Interim Topical Report
}

September 1981

Prepared for the U.S. Department of Energy under Contract DE-AC06-76RLO 1830

Pacific Northwest Laboratory Operated for the U.S. Department of Energy by Battelle Memorial Institute 


\title{
NOTICE
}

This report was prepared as an account of work sponsored by the United States Government. Neither the United States nor the Department of Energy. nor any of their employees, nor any of their contractors, subcontractors, or their employees, makes any warranty. express or implied, or assumes any legal liability or responsibility for the accuracy. completeness or usefulness of any information, apparatus, product or process disclosed, or represents that its use would not infringe privately owned rights.

The views, opinions and conclusions contained in this report are those of the contractor and do not necessarily represent those of the United States Government or the United States Department of Energy.

\author{
PACIFIC NORTHWEST LABORATORY \\ operated by \\ BATTELLE \\ for the \\ UNITED STATES DEPARTMENT OF ENERGY \\ Under Contract DE-AC06-76RLO 1830
}

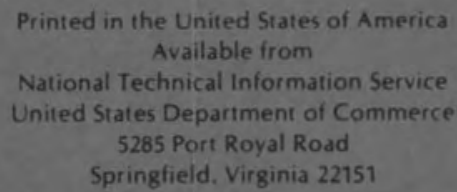

Price: Printed Copy $\mathbf{S}$ $\therefore$ Microfiche $\$ 3.00$

NTIS

*Pages Selling Price

001-025

$026 \cdot 050$

051-075

$076-100$

101-125

$126-150$

$151-175$

$176-200$

$201-225$

226-250

$251-275$

276-300

\section{$\$ 4.00$}

$\$ 4.50$

$\$ 5.25$

$\$ 6.00$

56.50

$\$ 7.25$

58.00

$\$ 9.00$

$\$ 9.25$

$\$ 9.50$

$\$ 10.75$

$\$ 11.00$ 

E. J. Wheelwright
D. H. Lester (a)
F. N. Hodges
T. L. Nakai(a)
L. A. Bray
M. E. Spaeth (a)
J. H. Westsik, Jr.
R. T. Stula(a)

September 1981

Prepared for

the U.S. Department of Energy

Office of Nuclear Waste Isolation

under Contract DE-AC06-76RL0 1830

Pacific Northwest Laboratory

Operated for the U.S. Department of Energy by Battelle Memorial Institute

(a) Science Applications Incorporated LaJolla, California 


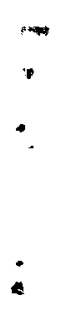




\section{CONTENTS}

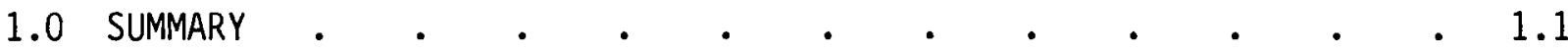

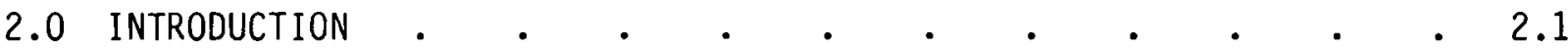

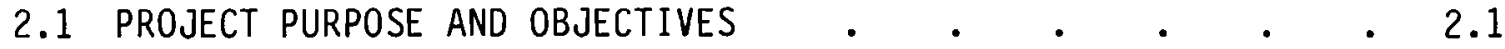

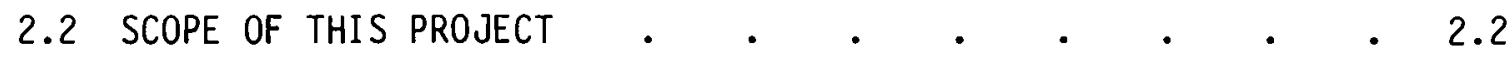

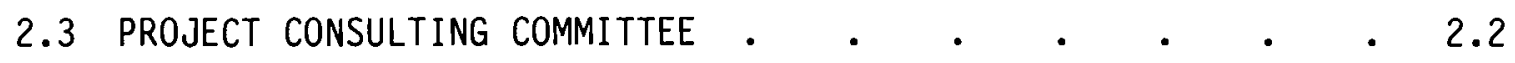

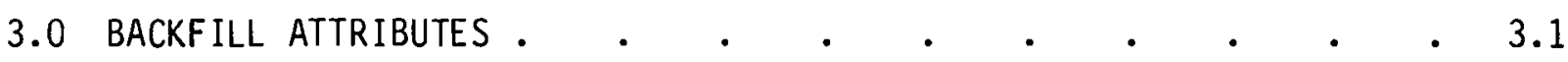

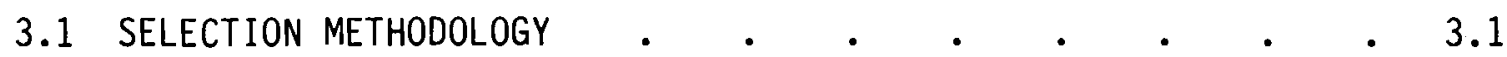

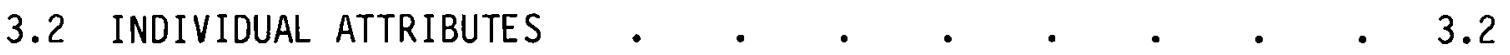

3.2.1 Minimization of Ground-Water Migration . . $\quad 3.2$

3.2.2 Retardation of Selected Chemical Species . . . 3.9

3.2.3 Control of $\mathrm{Eh}$ and $\mathrm{pH}$. $\quad . \quad . \quad . \quad . \quad . \quad 3.16$

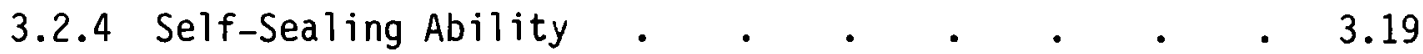

3.2.5 Thermal Stability of Backfill Material . . $\quad 3.24$

3.2.6 Radiation Stability . . . . . . . . 3.26

3.2.7 Heat-Transfer Capability . • • • • . $\quad 3.28$

3.2.8 Mechanical Stability . . . . . . . . 3.29

3.2.9 Long-Term Stability and Compatibility . . . . 3.33

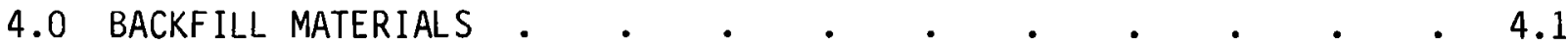

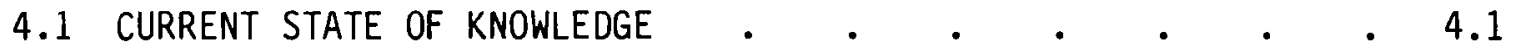

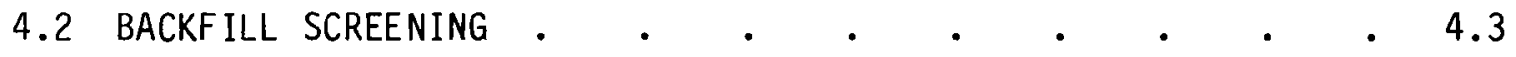

4.2.1 Sodium Bentonite/Sand Mixtures . . . . . . 4.3

4.2.2 Natural and Synthetic Zeolites . . . . . 4.5

4.2.3 Powdered Metals and Graphite . . . . . 4.6

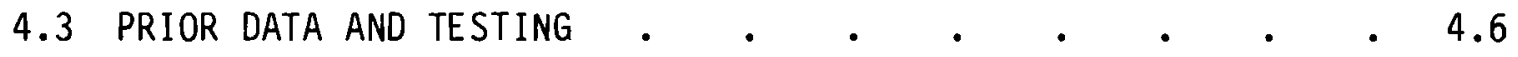


4.3.1 Water Exclusion $. \quad . \quad . \quad . \quad . \quad . \quad . \quad . \quad . \quad 4.6$

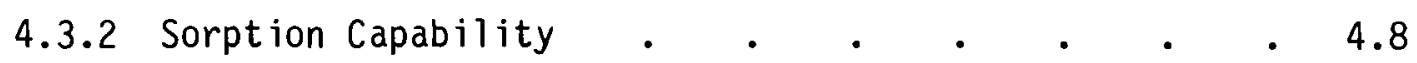

4.3.3 Control of $\mathrm{Eh}$ and $\mathrm{pH}$. $\quad . \quad$. $\quad . \quad$. 4.9

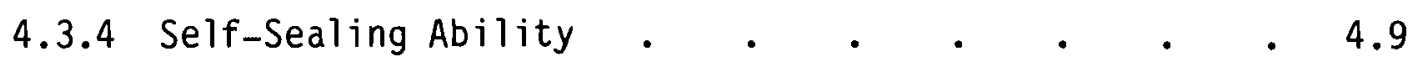

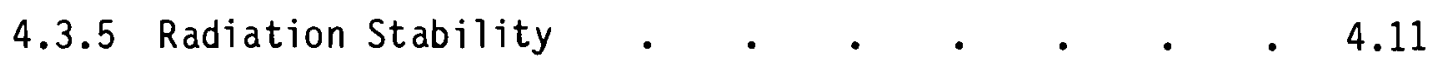

4.3.6 Heat-Transfer Capability . . . . . . 4.12

4.3.7 Mechanical Stabilty . . . . . . . . . 4.12

4.3.8 Long-Term Compatability and Stability . . . . 4.16

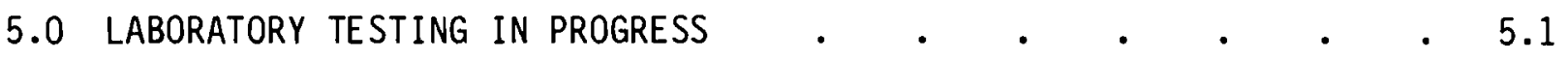

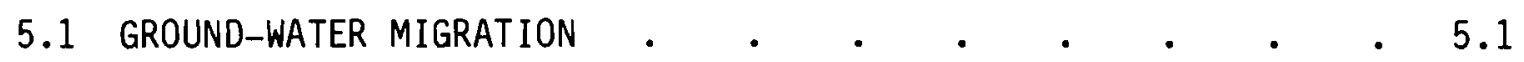

5.2 RETARDATION OF SELECTED CHEMICAL SPECIES • • • • 5.5

5.2.1 Batch Sorption Measurements . . . . . . 5.6

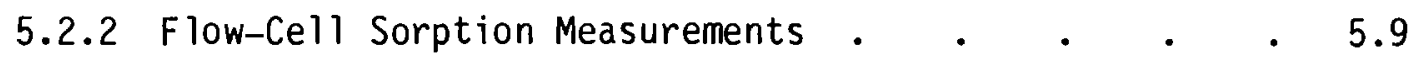

5.3 COMPACTION OF BACKFILL CANDIOATES $\quad$ • 5.15

5.4 MEASUREMENT OF CLAY SWELLING PRESSURES $\quad$ • $\quad$ • 5.18

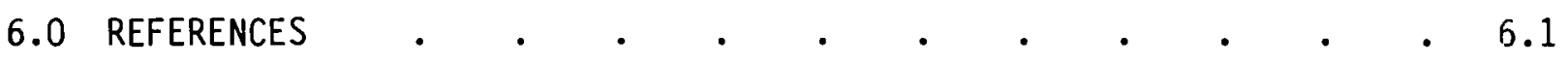

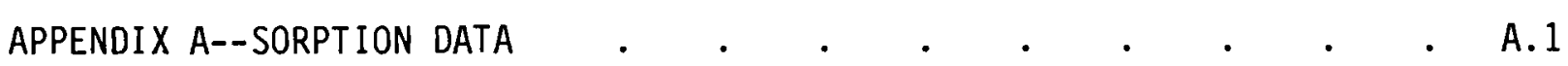




\section{FIGURES}

3.1 Observed Swelling Pressure Plotted Against Water Saturated Density for Compacted Sodium Bentonite

3.2 Comparative Measures of Redox in Natural Systems . . . . 3.18

3.3 Cell for Measurement of Bentonite Swelling . . . . . 3.23

3.4 ASEA Atom's Device for Determination of Extrusion Rates . $\quad 3.24$

3.5 Schematic of Triaxial Compression Chamber . . . . . 3.33

4.1 Hydraulic Conductivity Plotted Against Pressure Gradient for Samples of Compressed Sodium Bentonite . • • . • 4.7

4.2 Relationship Between Water Saturated Density and Hydraulic Conductivity . . • • . . . . . . . . 4.7

4.3 Swelling of Compacted Bentonite Into Space Between Parallel Plates Separated by $0.5 \mathrm{~mm}$. $. \quad . \quad . \quad . \quad . \quad . \quad . \quad . \quad .4 .10$

4.4 Stress/Strain Relationships in Simple Shear Tests for Non-Cemented

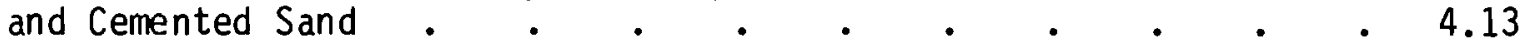

4.5 Approximate Relationship Between Void Ratio and Overburden Pressure . . . • . . . . . . . . 4.14

4.6 Rate of Consolidation of Modified Kaoline and Wyoming Bentonite . 4.14

5.1 Hydraulic Conductivity of $25 \%$ Sodium Bentonite Clay/75\% Fine Sand . . . . . . . . . . . . 5.3

5.2 Schematic of Water/Radionuclide Migration System . $\quad . \quad$ • 5.4

5.3 Schematic of Permeability Cell . $\quad$. $\quad$ • . . 5.5

5.4 Density of Sodium Bentonite as a Function of Compaction Pressure

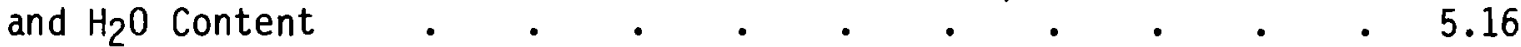

5.5 Density of Panther Creek Calcium Bentonite as a Function of Compaction Pressure and $\mathrm{H}_{2} \mathrm{O}$ Content 


\section{$\underline{\text { TABLES }}$}

4.1 Preliminary List of Candidate Backfill Materials . $\quad$ • $\quad$ • 4.4

4.2 Main Advantages and Disadvantages of Bentonite/Quartz Material $\quad 4.4$

4.3 Maximum Radiation Dose and Dose Rate $\quad . \quad$. $\quad . \quad$. $\quad . \quad$. 4.11

4.4 Compressive Strength of Sand and Clay Mixtures . . . . 4.15

4.5 Cation Exchange Capacity of Montmorillonite as a Function of

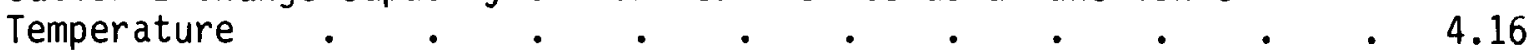

4.6 Thermal Stabilities of Selected Montmorillonites on Laboratory

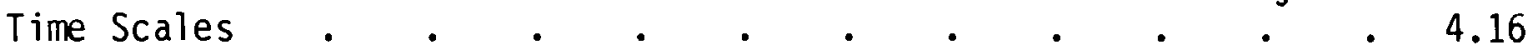

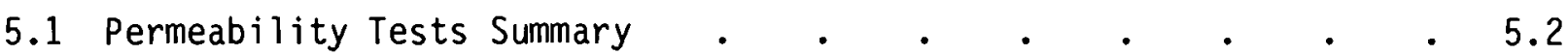

5.2 Composition of Ground Waters Under Investigation . $\quad . \quad$. 5.7

5.3 Batch Distribution Values for Backfill Candidates Ground Water: Grande Ronde, $\mathrm{pH} 9.85, \mathrm{pH} 8.6$. $\quad . \quad . \quad . \quad . \quad . \quad 5.10$

5.4 Analysis of Grande Ronde Ground-Water Effluent After Flowing Through Compacted 25 wt\% Sodium Bentonite/Sand: $\sim 1 \mathrm{~cm}$ Thick, $42 \mathrm{gm}, 2.16 \mathrm{gm} / \mathrm{cm}^{3}$. $\quad . \quad \ldots \quad . \quad . \quad . \quad . \quad . \quad . \quad . \quad 5.13$

5.5 Analysis of Grande Ronde Ground-Water Effluent After Passing Through Compacted $50 \mathrm{wt} \%$ Sodium Bentonite/50wt\% Sand: $\sim 1 \mathrm{~cm}$ Thick, $42 \mathrm{gm}, 2.1 \mathrm{gm} / \mathrm{cm}^{3}$. $. \quad . \quad . \quad . \quad . \quad . \quad$. 5.14

5.6 Analysis of Grande Ronde Ground-Water Effluent After Flowing Through Compacted 100 wt\% Calcium-Bentonite: $\sim 1 \mathrm{~cm}$ Thick, $42 \mathrm{gm}, 2.09 \mathrm{gm} / \mathrm{cm}^{3}$. $\quad . \quad . \quad . \quad . \quad . \quad . \quad . \quad . \quad . \quad 5.15$

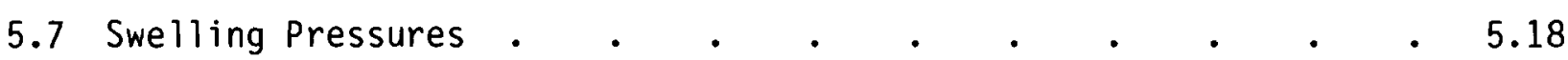

A.1 Batch sorption of $152 \mathrm{Eu}^{3+}$ with Different Competing Ion Concen-

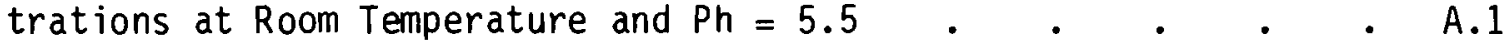

A.2 Characterization of Reference Sorbent Materials . • • • . A.2

A.3 Summary Results for Sorption of 238pu(IV) on Commercial Clays and Clay-Sand Mixtures . . . . . . . . . . A.2 
A.4 Batch Sorption of $243 \mathrm{Am}$ (III) on Commercial Clays, and Clay-Sand

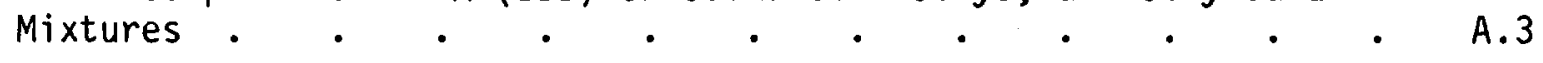

A.5 Water Composition Used in Swedish KBS Studies . . . . A.3

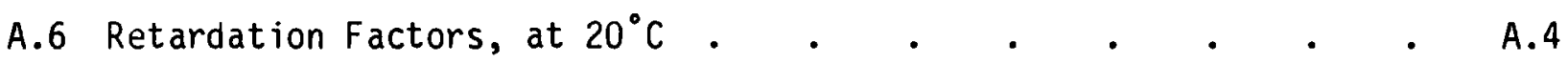




\subsection{SUMMARY}

A backfill barrier, emplaced between the containerized waste and the host rock, can both protect the other engineered barriers and act as a primary barrier to the release of radionuclides from the waste package.

Attributes that a backfill should provide in order to carry out its required function have been identyified. Attempts to arrange the required backfill attributes in order of importance have resulted in a division into primary and secondary attributes. Primary attributes are those that have a direct effect upon the release and transport of radionuclides from the waste package. Supportive attributes do not directly affect radionuclide release but are necessary to support the primary attributes.

The primary attributes, in order of importance, are:

1. Minimize (retard or exclude) the migration of ground water between the host rock and the waste canister system. Water is necessary for most, if not all, waste-package degradation mechanisms and all reasonable mechanisms of radionuclide transport. This attribute includes maximizing the time required for initial penetration of water through the backfill and minimizing the rate of percolation through the backfill after saturation.

2. Retard the migration of selected chemical species (corrosive species and radionuclides) in the ground water. Sorption on or reaction with backfill materials can significantly slow the migration of chemical species within the backfill. Retardation of the inward movement of species that enhance corrosion of the structural barriers may significantly increase the effective life of the barriers. Retardation of the outward movement of radionuclides from exposed waste should serve to slow the rate of radionuclide release from the waste package.

3. Control the Eh and $\mathrm{pH}$ of the ground water within the waste-package environment. The $\mathrm{Eh}$ and $\mathrm{pH}$ within the waste package environment will affect backfill stability, canister and overpack corrosion rates, 
waste form leaching rates, and radionuclide migration rates. Thus, buffering of Eh and $\mathrm{pH}$ may prolong containment by the structural barriers and decrease radionuclide release rates after they are breached.

The supportive attributes are generally considered to be of equal importance and no attempt has been made to place them in order of importance. The supportive attributes are:

- Self-seal any cracks or discontinuities in the backfill or interfacing host geology. The ability of the backfill to swell and deform plastically and seal voids or openings is important for support of the minimization of ground-water migration.

- Retain performance properties at all repository temperatures. The waste package will reach a maximum temperature soon after repository closure and will then slowly cool toward the ambient temperature over a period lasting for at least several thousand years. It is important that the backfill materials retain their desirable performance characteristics over the entire temperature range expected within the backfill.

- Retain performance properties during and after receiving repository levels of gamma radiation. The backfill must exist and function in the radiation field produced by the waste. It is important that the performance characteristics of the backfill materials not be adversely affected by either radiation induced structural damage or by chemical changes brought about by radiolysis.

- Conduct heat from the canister system to the host geology. The backfill, emplaced between the canister-overpack system and the host rock will, to a large extent, control the flow of heat from the waste package. Thus, the thermal conductivity of the backfill will determine the maximum temperature reached within the waste package and much of its subsequent thermal history.

- Retain mechanical properties and provide resistance to applied mechanical forces. The backfill must have sufficient mechanical 
strength to allow emplacement as preformed units, if that method of emplacement is chosen, and to provide support for the containerized waste. It is also important that, in resisting external forces, the backfill should deform plastically rather than fracturing and providing preferred paths for water migration.

- Retain morphological stability and compatibility with structural barriers and with the host geology for required period of time. The backfill materials must maintain their physical and chemical identities under the chemical conditions imposed by the presence of the other barriers and the host rock. If the backfill materials do not maintain their identities the other attributes of the materials are meaningless.

Screening and selection of candidate backfill materials has resulted in a preliminary list of materials for testing. Primary emphasis has been placed on sodium and calcium bentonites and zeolites used in conjunction with quartz sand or crushed host rock. In a multicomponent backfill utilizing these materials the bentonite clays contribute low permeability, high swelling pressure, and plasticity. Quartz sand or crushed host rock contribute mechanical strength and higher thermal conductivity, and zeolites contribute high ionexchange potential. Other materials are being considered as additives to enhance particular attributes.

Preliminary laboratory studies have concentrated on permeability, sorption, swelling pressure, and compaction properties of candidate backfill materials. The hydraulic conductivity for compacted sodium bentonite is less than $10^{-12} \mathrm{~cm} / \mathrm{sec}$ and increases to $7 \times 10^{-10} \mathrm{~cm} / \mathrm{sec}$ for $25 \%$ bentonite $/ 75 \%$ quartz sand mixtures. These values of hydraulic conductivity imply that for a hydraulic gradient of $1 \mathrm{~cm} / \mathrm{cm} 600,000$ years would be required for water to traverse $20 \mathrm{~cm}$ of pure sodium bentonite and 900 years would be required for ground water to traverse $20 \mathrm{~cm}$ of the $25 \%$ clay $/ 75 \%$ quartz sand mixture. 


\subsection{INTRODUCTION}

\subsection{PROJECT PURPOSE AND OBJECTIVES}

Concepts currently under investigation for the disposal of spent nuclear fuel or separated high-level nuclear waste involve emplacement of the waste in mined repositories in continental geologic formations. This strategy of isolating nuclear waste relies on a series of independently functioning barriers to restrict the release of radionuclides to the biosphere. The major parts of the disposal system are the waste package, the repository, and the natural geologic medium. Man can influence the functional properties of the natural geology only by exercising selection of the repository location. However, the waste package provides an opportunity to utilize ingenuity and skill to directly control the performance of a repository.

The waste package includes the waste form, the primary canister, one or more overpacks and the backfill. Backfill material will be used in the repository to $\mathrm{fill}$ the space between the canister-overpack system and the host rock, and to fill the mined drifts and tunnels when the repository is sealed. Careful engineering of the backfill material and methods of emplacement provide the opportunity to create an additional barrier system between the waste and the biosphere that can both support the other barriers in performing their design functions and, simultaneously, provide additional redundant barrier functions. This project is directed at backfill surrounding the canister-overpack. The backfill might be a single material but is more likely to be a combination of two or more materials.

The objectives of the backfill development program are to:

1. Define and prioritize the desired attributes of the backfill,

2. Screen potential backfill materials and select the most promising for laboratory evaluation,

3. Evaluate the most promising materials or material combinations by measuring their performance in laboratory testing and comparing the measured performance against the defined requirements. 


\subsection{SCOPE OF THIS PROJECT}

Funding for the backfill project at Pacific Northwest Laboratory (PNL) was initiated in mid-FY 1980. During the remainder of that year, the effort was divided into four activities:

1. Preliminary laboratory screening tests,

2. Definition and prioritizing of backfill functional requirements,

3. Screening of potential backfill materials on the basis of published properties and engineering judgment,

4. Preparation for the extensive laboratory testing program which included planning and prioritizing the tests to be performed, acquiring equipment and materials, and initiating of testing.

Through a subcontract with Science Applications, Inc. (SAI), Dr. David Lester and coworkers were assigned activities 2 and 3 . As a basis for their work, they performed an extensive literature search and engineering evaluation which is incorporated in this report. Activities 1 and 4 were performed at PNL and are continuing. Section 5.0 reports experiment progress to date. Section 5.0 is only a progress report and is not intended to be a basis for conclusions.

\subsection{PROJECT CONSULTING COMMITTEE}

At the inception of the project, a consultant committee was formed. People of recognized stature were selected. A deliberate effort was made to recruit people with complimentary areas of expertise. Members of the Committee are:

Dr. R. A. Berner--Yale University

Dr. A. Lerman--Northwestern University

Dr. W. L. Lindsay--Colorado State University

Dr. P. F. Low--Purdue Univeristy

Dr. R. Rollins--Brigham Young University

Dr. Lindsay's interests are in the application of electrochemistry to soils, minerals and ground water. Dr. Low is interested in the area of 
clay-water interactions. Dr. Berner's areas of interest include lowtemperature geochemical processes and sediment diagenesis. Dr. Lerman's field of interest is geochemical modeling. Dr. Rollins was selected because of his engineering experience in the structural aspects of clays.

The committee has reviewed the project research plans, and reviewed and commented on published work from other backfill programs. They will critique our experimental results and conclusions. We anticipate that the work may result in some jointly authored publications. 



\subsection{BACKFILL ATTRIBUTES}

The identification of necessary backfill attributes is a vital first step in the development of a viable backfill for nuclear waste isolation. In this section, the selection methodology for determining a prioritized listing of backfill material attributes is discussed. An initial list of attributes along with associated experimentally measurable properties was evaluated and reduced to include only the attributes most important to waste package performance. In this section the individual attributes are defined in both conceptual and technical terms and their interrelationships are discussed. In addition, methods of experimentally measuring the attributes are discussed.

\subsection{SELECTION METHODOLOGY}

A preliminary unordered list of possible backfill attributes was developed and issued by Science Applications, Inc. (SAI). After review and comment by members of the Project Consulting Committee and both SAI and PNL contributors, a preliminary prioritized listing was prepared. The attributes were classified into general technical areas and prioritized within these areas. At that point, no attempt had been made to develop overall priority rankings for the attributes.

After a second review by the participants named above, a modified delphi method was used to condense the list and to establish priority. All of the attributes were considered to fall into one of two general categories:

Primary Attributes--Attributes that have a direct effect on the release and transport of radionuclides from the repository to the biosphere,

Supportive Attributes-Attributes that do not in themselves affect package performance, but are necessary to support the primary performance attributes.

It was decided that any ranking of supportive attributes could be misleading due to their indirect effect on package performance. Therefore supportive attributes were generally considered to be of equal importance. Primary 
attributes, however, were considered to be of unequal importance and were ranked in the order of appearance in the following listing:

Primary Attributes

1. Minimize (retard or exclude) the migration of ground water between the host geology and the waste canister system.

2. Retard the migration of selected chemical species (corrosive species and radionuclides) in the ground water.

3. Control the $\mathrm{Eh}$ and $\mathrm{pH}$ of the ground water within the waste-package environment.

Supportive Attributes

- Self-seal any cracks or discontinuities in the backfill or interfacing host geology.

- Retain performance properties at all repository temperatures.

- Retain performance properties during and after receiving repository-levels of gamma radiation.

- Conduct heat from the canister system to the host geology.

- Retain mechanical properties and provide resistance to applied mechanical forces.

- Retain morphological stability and compatibility with structural barriers and with the host geology for required period of time.

\subsection{INDIVIDUAL ATTRIBUTES}

\subsubsection{Minimization of Ground-Water Migration}

\subsubsection{Conceptual Definition}

The presence of water is a key factor in most waste-package and waste-form degradation mechanisms and water is the only reasonable agent for transport of radionuclides within or from a geologic repository. Therefore, minimizing the 
migration of ground water between the host geology and the containerized waste is the single most important function of the backfill.

The design life of the backfill can be conveniently divided into two periods. The first period, prior to saturation of the backfill, is one of complete water exclusion. During the second period, after saturation of the backfill, movement of water through the backfill will be controlled by the hydraulic properties of the backfill materials and by the regional hydraulic gradient.

The length of the first period, the time required for water to reach the containerized waste, will depend upon how rapidly water can migrate through the host rock to the backfill and the time required for water to soak through the backfill material. The time required to migrate to the backfill will depend upon the site geology and upon thermal and hydraulic gradients around the waste package. The time required to saturate the backfill is a complex function of clay properties, particularly for highly compacted montmorillonites (bentonites) and will require careful experimental evaluation. However, on the basis of incomplete preliminary evidence and assuming the integrity of the backfill is not compromised by some type of catastrophic event, it is not unreasonable to predict that a properly designed and emplaced backfill may be capable of completely excluding water from the containerized waste for a period of several hundred to several thousand years.

Water movement through the backfill after saturation will be controlled by the hydraulic conductivity of the backfill and the regional hydraulic gradient. Experimental evidence (Kharaka and Smalley 1976) indicates that highly compacted and confined montmorillonite clays (bentonites) have hydraulic conductivities on the order of $10^{-12} \mathrm{~cm} / \mathrm{sec}$ or less. Hydraulic conductivities of this magnitude, coupled with reasonable regional hydraulic gradients, would result in extremely low flow velocities through the backfill. Under these conditions of very slow flow, diffusion of solutes through the interstitial solution would be the principal means of transport through the the backfill.

The mechanisms and kinetics by which ground-water hydrates highly compacted and confined montmorillonite (bentonite) clay and migrates through the 
clay are not clearly understood. Nevertheless, because of the potential significance a backfill containing such material can have for ground-water migration rates, two concepts should be thoughtfully examined.

If the backfill can be viewed as a system of hypothetical concentric layers, during the first period of backfill life, ground water will migrate from the host geology into the interfacing layer of backfill and the clay in that layer will begin to hydrate and to exert a swelling pressure. Before ground water can reach the second layer of backfi11, it must migrate through the first layer which has at least started the hydration-swelling process and may have largely completed the process. It is premature to quantify the rate at which the hydration process moves through such a backfill (experiments are in progress to do this) but the migration rate of the hydration process should not be more than an order of magnitude different than the migration rate of the hydrating water through previously hydrated backfill. On this basis it seems reasonable that the time required for water to penetrate and saturate $20 \mathrm{~cm}$ of backfill will be on the order of several thousand years.

The second concept relates to the time required for a significant volume of water to reach the canister system, equilibrate with the system and then continue migration down the hydraulic gradient. If a canister-overpack assumed to be $1 \mathrm{~m} \mathrm{O.D} \times 3 \mathrm{~m}$ high, then the volume of such a cylinder is $2.36 \mathrm{~m}^{3}$ and the external surface area is $11 \mathrm{~m}^{2}$. Then assume ground water approaches the cylinder through 50\% of the surface area and recedes from the cylinder through the remaining $50 \%$ of the surface area. A volume of groundwater equivalent to the volume of the cylinder is small compared to the volume required to corrode through the overpack and canister. If a conservative regional hydraulic gradient of 1.0 and a conservative hydraulic conductivity of $1 \times 10^{-11} \mathrm{~cm} / \mathrm{sec}$ are applied to this example, the additional time required for the first "equivalent volume" of ground water to contact the cylinder after ground water finally reaches the cylinder in this simplistic model and calculation is $1.4 \times 10^{5}$ years.

Major objectives of the backfill program are first to carefully measure the hydraulic conductivities and saturation time of candidate materials to 
validate the low number assumed in the previous paragraph and then to show that the backfill hydraulic properties will remain effective for the required period of time.

\subsubsection{Technical Definition}

The movement of water through solid media is generally described in terms of Darcy's law

$$
Q=-K i A
$$

where

$$
\begin{aligned}
Q & =\text { discharge rate }\left(\mathrm{cm}^{3} / \mathrm{sec}\right) \\
K & =\text { hydraulic conductivity }(\mathrm{cm} / \mathrm{sec}) \\
\mathbf{i} & =\text { hydraulic gradient }(\mathrm{cm} / \mathrm{cm}) \\
A & =\text { cross-sectional area }\left(\mathrm{cm}^{2}\right)
\end{aligned}
$$

In the formalism of Darcy's law, the hydraulic conductivity, $K$, is a constant relating discharge to hydraulic gradient. It is a function of both the solid material and the fluid as indicated by the relationship (Hubbert 1940):

$$
K=\frac{k \rho g}{n}
$$

where

$$
\begin{aligned}
& k=\text { permeability }(" \text { intrinsic" })\left(\mathrm{cm}^{2}\right) \\
& \rho=\text { fluid density }\left(\mathrm{gm} / \mathrm{cm}^{3}\right) \\
& \eta=\text { fluid viscosity }(\mathrm{gm} / \mathrm{cm}-\mathrm{sec}) \\
& \mathrm{g}=\text { gravitational acceleration }\left(\mathrm{cm} / \mathrm{sec}^{2}\right)
\end{aligned}
$$

The permeability, $k$, is entirely a function of the solid media and depends upon variables such as grain size, grain shape, porosity and path tortuosity. The density and viscosity factors depend entirely upon the fluid phase and the dependence on viscosity clearly indicates that hydraulic conductivities vary strongly with temperature. 
Darcy's law is valid over a wide range of conditions; however, there are conditions under which it is not valid. It has long been recognized that Darcy's law is invalid under conditions of very high discharge rate where turbulent flow develops (Freeze and Cherry 1979). There is also evidence that it may not be valid for very low flow rates in fine-grained low permeability materials (Swartzendruber 1962; Bolt and Groenevelt 1969). Of direct interest to the problem of minimizing ground-water migration by backfills is the evidence presented by Kharaka and Smalley (1976) and Pusch (1979b) that highly compacted bentonites exhibit non-Darcian behavior. In both studies it was found that the hydraulic conductivity of the clays decreases with decreasing hydraulic gradient. These results mean that with the low hydraulic gradients that will exist in and near a geologic repository, the rate of migration of ground water through a compacted, hydrated clay backfill will be less than the rate predicted by Darcy's law.

Some measure of understanding of the hydraulic properties of clays can be gained by considering the microscopic geometry of flow through clays. Clays are layer silicates and, in many cases, occur as flat sheet-like grains. Thus, as a first approximation it is useful to consider the flow of fluid between parallel flat plates. According to Poiseuille's law this flow is described by

$$
Q=\Delta P \lambda^{3} / 12 \eta
$$

where

$$
Q=\text { flow rate }\left(\mathrm{cm}^{3} / \mathrm{sec}\right)
$$

$\Delta P=$ pressure $\operatorname{drop}\left(\right.$ dynes $/ \mathrm{cm}^{2}$ )

$\lambda=$ spacing between plates $(\mathrm{cm})$

$\eta=$ viscosity of fluid (dyne $\mathrm{sec} / \mathrm{cm}^{2}$ )

From this relationship it can be seen that flow depends quite strongly upon the interlayer spacing. Further, Low (1976) has shown that for montmorillonite clays the interplate distance, $\lambda$, is given by

$$
\lambda=2\left(M_{W} / M_{m}\right) / \rho S
$$


where

$$
\begin{aligned}
\rho & =\text { density of interplate water }\left(\mathrm{gm} / \mathrm{cm}^{3}\right) \\
S & =\text { specific surface area of the clay }\left(\mathrm{cm}^{2} / \mathrm{gm}\right) \\
M_{w} / M_{m} & =\text { mass ratio of water to dry montmorillonite }
\end{aligned}
$$

This relationship between the mass ratio of water to montmorillonite and the interplate spacing, $\lambda$, is significant because the swelling pressure developed within montmorillonite clays also varies strongly as a function of the same ratio (see Section 3.2.4.2). Thus, in a water-saturated clay body the interplate spacing and thus the ability to transmit water will decrease with increasing swelling pressure.

The reported non-Darcian behavior of highly compacted montmorillonites can be understood by a similar line of reasoning. At high densities, the swelling pressure developed by confined montmorillonite varies strongly with density, i.e., a small change in density results in a relatively large change in swelling pressure (Figure 3.1). A major reason for this behavior is the ability of the confined clay to expand and fill the available pore volume within the clay body. Thus, as density is increased the pore volume available for expansion is decreased and the observed external swelling pressure increases.

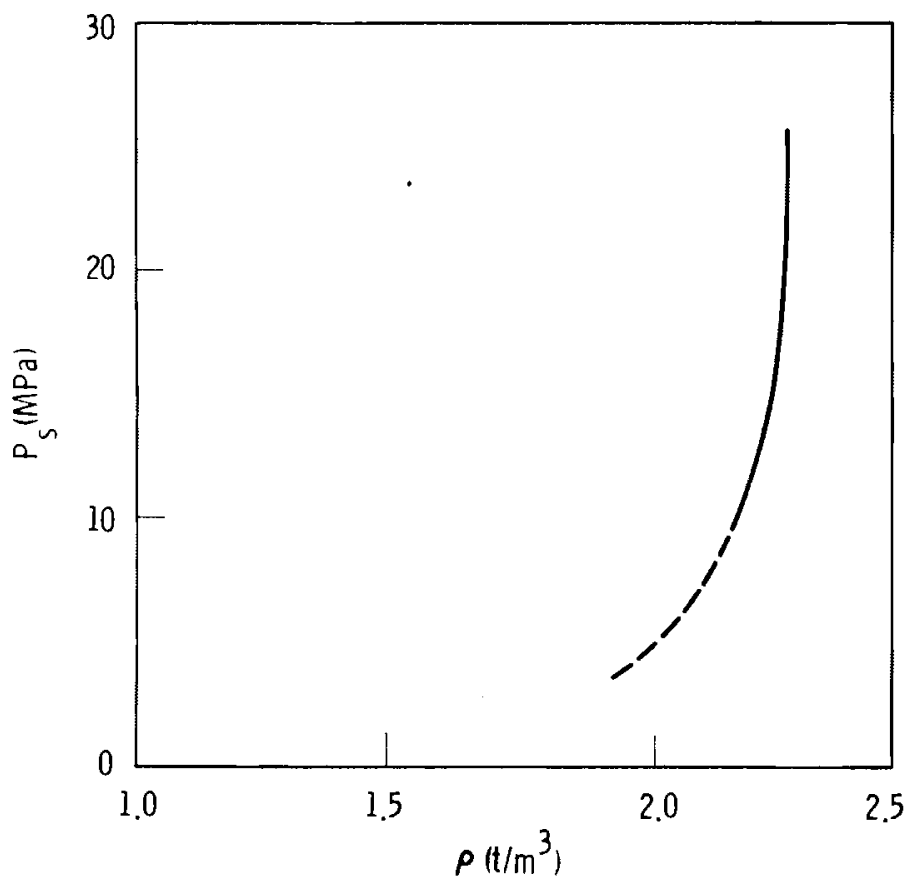

FIGURE 3.1. Observed Swelling Pressure (Ps) Plotted Against Water-Saturated Density $(\rho)$ for Compacted Sodium Bentonite (after Pusch 1979c) 
Permeability measurements for highly compacted montmorillonites have been carried out under high water pressure (high hydraulic gradient) to achieve results within a reasonable time period. Under these conditions the clay will swell and expand into the available pore volume until the swelling pressure is balanced by the forces opposing collapse, including the applied water pressure, capillary forces, and repulsive forces between the clay particles. If the water pressure is decreased the clay will expand further into the pore volume until the swelling pressure is once again balanced by the opposing forces. Thus, in experiments of this type the porosity of the sample, generally considered an intrinsic property of the material, will vary with the imposed water pressure. This decrease in porosity with decreasing applied water pressure should result in a decrease in the "intrinsic" permeability, $k$, and thus in the hydraulic conductivity, $K$, (see Equation 3.2).

In a fully saturated montmorillonite clay the value for the hydraulic conductivity may decrease to the point where diffusion through the interlayer water may become the principal mechanism of transport through the backfill. Diffusion and the transport of radionuclides through materials have been discussed extensively by Nerentnieks (1977). Diffusion in clays (Low 1976) is described by:

$$
D_{i}=\frac{\beta b_{i} T}{n^{0}} \exp \left[-244 /\left(M_{w} / M_{m}\right) R T\right]
$$

where

$$
\begin{aligned}
& D_{i}=\text { diffusion coefficient for ion } i\left(\mathrm{~cm}^{2} / \mathrm{sec}\right) \\
& \beta=\text { diffusion path geometry factor }\left(\mathrm{g} /{ }^{\circ} \mathrm{K}-\mathrm{sec}^{2}\right) \\
& b_{j}=\text { radius of ion-related factor }(\mathrm{cm}) \\
& T=\text { absolute temperature }\left({ }^{\circ} \mathrm{K}\right) \\
& n^{0}=\text { viscosity of pure bulk water at } T(\mathrm{~g} / \mathrm{cm}-\mathrm{sec}) \\
& R=\text { molar gas constant }\left(\mathrm{Kcal} / \text { gmole- }{ }^{\circ} \mathrm{K}\right) \\
& M_{w} / M_{m}=\text { mass ratio of water to montmorillonite } \\
& \text { Diffusion is discussed elsewhere in this report (see subsection 3.2.2). }
\end{aligned}
$$




\subsubsection{Methods of Measurement}

Permeability of a material can be measured in the laboratory or in the field. Reeve and Luthin (1957) describe techniques of measurement both in the field and in the laboratory. Gillott (1968) discusses measurement of permeability for soils using a constant head permeator. The measurement of permeability to characterize and rank backfills by the Gillott method would require a long time periods because of the low hydraulic heads and low flow rates. The technique chosen for the PNL backfill program is similar to that used by Kharaka and Smalley (1976) for the measurement of permeabilities of highly compacted clays. The PNL system will also al low measurement of radionuclide retardation and swelling pressure on the same samples (see Section 5.0). The diffusion of the ion species through highly compacted clays will also be determined as part of this program.

\subsubsection{Retardation of Selected Chemical Species}

\subsubsection{Conceptual Definition}

After saturation of the backfill, chemical species may be transported through the backfill either by movement of water, or if the backfill performs as expected, by diffusion through the interstitial water. In either case the ability of the backfill to retard the migration by sorption, precipitation, or any other mechanism is one of the more important attributes of the backfill. Sorption is discussed in this section. Precipitation is controlled by Eh and $\mathrm{pH}$ and is discussed in Section 3.2.3.

The ability of the backfill to sorb and thus retard the rate of transport of many chemical species has two important effects. First, by slowing the inward movement of corrosion agents and the outward movement of corrosion products from the hard barriers, the sorptive ability of the backfill should significantly reduce overpack and canister corrosion rates and thus extend the effective life of the hard barriers. The retardation of corrosion products should be much more effective than the retardation of corrosive agents because many of the agents that produce corrosion are anions that are weakly sorbed. Second, by slowing the rate of radionuclide transport through the backfill, the 
sorptive capability of the backfill will significantly reduce the rate of radionuclide release after failure of the hard barriers.

Sorption capability can be defined in two different ways: capacity and retardation. Capacity refers to the maximum amount of a chemical species that the backfill could hold if all the sorption sites were fully loaded. Capacity is generally related to an assumed irreversibility in the loading process, i.e., the desorption rates are so low that the sorption is essentially permanent until the material is fully loaded (no more sites) or until chemical conditions are changed (e.g., pH or oxidation potential). In some systems there is a significant tendency for species to desorb while sorption is taking place, thus establishing a partition between solution and solid. The system may achieve equilibrium or may display finite forward and backward rates approaching but not achieving full equilibrium. In this case a retardation factor or partition coefficient description is more appropriate.

The issue of kinetics is not discussed in this section. While kinetics is often important in ion-exchange processes, we are dealing here with very slow effects evolving over hundreds or thousands of years. It is likely that thermodynamic equilibrium is normally maintained and that rates of reactions are not a significant influence. Kinetic effects may be very important, however, in short term experiments designed to measure sorption effects.

Two other effects that must be considered, both in the experimental determination of sorption parameters and in their application to the real world are the effect of speciation on the sorption of particular elements and the effect of competition between various ions for the finite number of available sorption sites. Speciation will depend on both the availability of complexing agents in the solution and upon the $\mathrm{Eh}$ and $\mathrm{pH}$ of the solutions. The competition for available sorption sites will depend on both the types and the concentrations of the ions existing in the solution. The competition for existing sites will be strongly influenced by the speciation of the elements involved.

\subsubsection{Technical Definition}

Many properties of the material help to determine the sorption capability of a candidate backfill. These include: 
- bulk density

- specific surface area

- sorption sites per unit surface area,

- chemical properties of the sorption site.

of equal importance is the chemical environment, i.e., Eh and $\mathrm{pH}$, concentration of various species, temperature, and pressure. The sorption capability of the material cannot be specified without also specifying these other environmental quantities. Of course, sorption capability is specific to each nuclide or ion of interest.

\section{Capacity}

Capacity is usually measured through the use of breakthrough experiments. It is defined as the quantity of the species of interest (usually in grams) per unit volume (liters) or per weight of solid (grams or kilograms) that can be sorbed in a sample of the solid.

Implied in such a measurement is irreversibility, i.e., significant desorption does not take place until conditions are altered and the solute is eluted from the solid. This value is generally referred to as "stoichiometic capacity" of the ion-exchange medium.

Generally speaking, most natural materials including clays do not display irreversible ion-exchange capacity. Rather there is a measurable equilibrium partition between solution and solid so that under continuous flow conditions all the species ultimately will elute from the backfill. However, materials such as silver zeolites or lead zeolites can display an irreversible capacity and trap a fixed amount of material for long periods of time under fixed chemical/physical conditions.

In equilibrium systems with measurable desorption, a "quasi-capacity" is displayed if the total solution or solute-free water flowing through is less than that necessary to cause breakthrough. Therefore, there is a minimum amount of total flow required to move the chromatographic front out of the backfill. 


\section{Retardation}

Retardation is the more commonly observed property of backfill candidates, especially natural clays. In this case, the solute will partition between solid and solution with both forward and backward transport present. If equilibrium is reached, the process is characterized by a "distribution coefficient, ) $k_{d}$ as

$$
k_{d}=\frac{c_{s}}{c_{1}}
$$

where

$$
\begin{aligned}
C_{s}= & \text { the concentration of sorbing species in or on the solid } \\
& \text { phase (gm/gm of solid) } \\
C_{1}= & \text { the concentration of sorbing species in the liquid phase }(\mathrm{gm} / \mathrm{m} 1 \\
& \text { of solution) }
\end{aligned}
$$

In a classical approach, the $k_{d}$ would be the slope of a linear adsorption isotherm. In reality the isotherms are not linear with concentration and as a result, $k_{d}$ is a function of concentration. However, in the system of interest, low mass concentrations and concentration dependence may not be signficant. Nevertheless, the favorite approach is to measure $K_{d}$ for specific concentration conditions. Such values are useful for comparative studies of backfills and for initial estimates of system capability. Measurements under exact conditions are necessary to ensure accurate estimates of retardation capability.

Retardation gets its name from the fact that a nuclide band injected into the material will move through the material under flow or diffusion conditions but will move more slowly than the bulk solution. If

$$
K=1+\frac{\rho K_{d}}{\varepsilon}
$$


where

$$
\begin{aligned}
\rho & =\text { solid bulk density }(\mathrm{gm} / \mathrm{ml}) \\
K_{d} & =\text { distribution coefficient }(\mathrm{ml} / \mathrm{gm}) \\
\varepsilon & =\text { void fraction (dimensionless) }
\end{aligned}
$$

then the dimensionless constant, $k$, is the ratio of bulk flow velocity to nuclide velocity. If there is no bulk flow but only diffusion, as would often be the case in a waste package, and if $D$ is the diffusivity of solute through the pore solution, then $D / K$ is the effective diffusivity of the solute.

\subsubsection{Methods of Measurement}

\section{Capacity}

Capacity measurements may be done either in batch or flow experiments. Flow experiments are preferred because subtle flow and geometric effects can be included as long as it is reasonably assured that flow and geometry are matched to the "real" system. In the flow experiment a solution is passed through the material at a fixed temperature and flow rate ${ }^{(a)}$ until breakthrough occurs. Breakthrough is described as some threshold exit concentration. Typially such experiments are run with material packed in a column, often made of glass or clear plastic to allow visual evaluations of the experiment. After breakthrough, the solution flow is stopped, the column washed, and then eluted to measure the total amount of material retained. The capacity can also be calculated from the volume of solution passed through the column plus the influent and effluent concentrations.

Batch experiments using small agitated samples are sometimes carried out. This involves contacting a relatively large volume of solution with a small solid sample and measuring the total uptake after separation and extensive washing. While such testing gives a maximum sorption potential, the results are difficult to relate to the real system.

(a) Note that in making such measurements, kinetics can be an important factor. 


\section{Retardation}

As with irreversible capacity, $K_{d}$ values can be measured in the batch or flow mode with similar relative merits for the two alternatives.

In the flow mode a tracer pulse of solute is injected in one end of a flow column and the response elution pulse at the other end is measured. For a narrow pulse the Green's function is (Lester et al. 1975)

$$
N=N^{0} \frac{V}{2 L} \sqrt{\frac{K P}{\pi \theta^{3}}} \exp \left[-\frac{P \theta}{4 K}\left(\frac{K}{\theta}-1\right)^{2}\right]
$$

where

$$
\begin{aligned}
\mathrm{N} & =\text { discharge rate }(\mathrm{Ci} / \mathrm{sec}) \\
\mathrm{V} & =\text { velocity }(\mathrm{cm} / \mathrm{sec}) \\
\mathrm{L} & =\text { length of column }(\mathrm{cm}) \\
\mathrm{N}^{\mathrm{O}} & =\text { input pulse }(\mathrm{Ci}) \\
\mathrm{K} & =\text { constant }[\text { Equation }(3.7)] \text { (dimensionless) } \\
\theta & =\text { dimensionless time }=\mathrm{tV} / \mathrm{L} \\
\mathrm{t} & =\text { time }(\mathrm{sec}) \\
\mathrm{P} & =\text { Peclet Number }=\mathrm{VL} / \mathrm{D}(\text { dimensionless) } \\
\mathrm{D} & =\text { dispersion coefficient }\left(\mathrm{cm}^{2} / \mathrm{sec}\right)
\end{aligned}
$$

If the dispersion coefficient, $D$, is well known, then the value of $K$ can be derived from the results by fitting the breakthrough data. Where the value of $D$ is vanishingly small

$$
N=\frac{N^{0} V}{L} \delta(\theta-K)
$$

where $\delta=a$ unit impulse function occurring at dimensionless time $\theta=K$. In this case, breakthrough time, $t_{B}$, gives the value of $k$

$$
K=\frac{t_{B} V}{L}
$$


Where there is significant decay (chemical or nuclear of the tracer with a decay rate constant of $b$, the value of $N$ is modified by a factor, $f$

$$
f=e^{-b t}
$$

and the procedure is the same as described above.

Rather than a pulse, it is desirable to use a finite width input or band. In this case, the column output is (Lester et al. 1975)

$$
\begin{aligned}
N= & \frac{N^{0}}{2 B}\left\{\operatorname { e x p } ( - J \theta ) \left[\operatorname{erfc}\left(\sqrt{\frac{K P}{4 \theta}}-\sqrt{\frac{P \theta}{4 K}}\right)\right.\right. \\
& \left.+\exp (P) \operatorname{erfc}\left(\sqrt{\frac{K P}{4 \theta}}+\sqrt{\frac{P \theta}{4 K}}\right)\right] \\
& -\left[\exp \left(-J\left(\theta-\theta_{B}\right)\right)\right]\left[\operatorname{erfc}\left(\sqrt{\frac{K P}{4\left(\theta-\theta_{B}\right.}}-\sqrt{\frac{P\left(\theta-\theta_{B}\right)}{4 K}}\right)\right] \\
& \left.+\exp (P) \operatorname{erfc}\left(\sqrt{\frac{K P}{4\left(\theta-\theta_{B}\right)}}+\sqrt{\frac{P\left(\theta-\theta_{B}\right)}{4 K}}\right)\right\}
\end{aligned}
$$

where

$$
\begin{aligned}
B & =\text { time width of band }(s) \\
\theta_{B} & =\text { width of pulse in dimensionless time }=B L / V \text { (dimensionless) } \\
J & =b 1 / V
\end{aligned}
$$

and the procedure is the same as described above. A variation of this type of test, particularly applicable to the present study, is the injection of a continuous band of radionuclide at the solubility limit of that radionuclide.

Batch measurements of $k_{d}$ are popular because of simplicity and ease of analysis. Solution and solid are contacted at controlled temperature in a container and allowed to equilibrate. The concentration in the liquid phase is determined by chemical analysis or by counting techniques and the $k_{d}$ is given by 


$$
K_{d}=\frac{V_{L}}{W}\left[\frac{N_{f}-N_{S}}{N_{S}}\right]
$$

where

$$
\begin{aligned}
V_{L} & =\text { volume of liquid added to batch sample }(\mathrm{ml}) \\
W & =\text { mass of solid added to batch sample }(\mathrm{gm}) \\
N_{f} & =\text { feed liquid concentration }(\mathrm{gm} / \mathrm{ml}) \\
N_{S} & =\text { filtered supernate concentration }(\mathrm{gm} / \mathrm{ml})
\end{aligned}
$$

$N_{f}$ is generally established by counting blanks of standard feed which are carried through the process with omission of the solids.

The approach used in the PNL backfill program is a combination of batch and dynamic flow-through determinations. Initial tests will measure batch $k_{D}$ for selected backfill materials under carefully controlled conditions. Later tests, coupled with permeability tests, will measure the retardation of selected radionuclides in compacted backfill materials. All determinations will be carried out with geology-specific ground-water compositions and under conditions of carefully controlled Eh and $\mathrm{pH}$.

\subsubsection{Control of Eh and $\mathrm{pH}$}

\subsubsection{Conceptual Definition}

Chemical buffering refers to the ability of the backfill to maintain a desirable chemical environment within the waste package. Some degree of chemical buffering may be provided by the major backfill components. The hydrolysis of clay may, for instance, help to buffer the $\mathrm{pH}$ and the presence of a zeolite may help control the concentration of $\mathrm{Ca}^{2+}$ and $\mathrm{K}^{+}$in the backfill. If, however, analysis of the waste package and the host rock geochemistry indicate that chemical buffering is needed, it will be carried out principally by minor components added to the backfill because of their ability to control one or more chemical parameters.

The effects of chemical buffering may influence several backfill properties and functions. The buffering of Eh and $\mathrm{pH}$ may strongly influence corrosion of the overpack and canister and buffering of $\mathrm{pH}$ may enhance the stability 
of the backfill. In addition, after failure of the hard barriers, buffering of Eh and pH may influence leaching of the waste form, solubility of radionuclides, and transport properties of many of the radionuclides. It may also prove desirable in some cases to buffer or control the concentrations (activities) of other chemical species in solution. The stability of the backfill clay may be enhanced by buffering $\mathrm{K}^{+}, \mathrm{Ca}^{2+}$, or silica in the interstitial fluid. Buffering of various anionic species $\left(\mathrm{Cl}^{-}, \mathrm{F}^{-}, \mathrm{SO}_{4}^{=}\right)$that occur in natural ground waters may be desirable to prolong the life of the overpack and canister and to reduce the concentrations of complexing agents at the waste form interface.

It is important to realize that the ability of a backfill to maintain a chemical environment that is significantly different from that in the host rock will strongly depend on the amount of communication that exist between the host rock and the backfill. If the system is relatively open, either through water flow or diffusion, the effective life of the buffer will be strongly limited because of the much greater mass of the host rock. However, because of the finite and, in many cases, relatively short half-lives of the radionuclides it is not important that the buffer substances last indefinitely. Their role is sacrificial and it is only necessary that they buy a certain, limited amount of time for containment.

\subsubsection{Technical Definition}

The $\mathrm{pH}$ and $\mathrm{Eh}$ of the aqueous phase are intensive parameters that to a large extent serve to define a particular geochemical environment. $\mathrm{pH}$ is defined as the negative log of the hydrogen ion $\left(\mathrm{H}^{+}\right)$activity. Eh is defined as the difference in potential, measured in volts, between a platinum electrode and a standard hydrogen electrode. Another commonly used measure of the redox state of a system is pe, which by analogy with $\mathrm{pH}$, is defined as the negative $\log$ of the electron activity. The relationship between pe and Eh is given by

$$
\text { Eh (millivolts) }=59.2 \text { pe }
$$

A comprehensive discussion of $\mathrm{Eh}$ and $\mathrm{pH}$ in natural systems is given by Garrels and Christ (1965). Lindsay (1979) discusses the use of redox concepts in soil 
chemistry. The relationships between various measures of redox state are presented in Figure 3.2 (Lindsay 1979). In an aqueous system, hydrogen and oxygen are linked by the dissociation reaction of water. Thus, at equilibrium, fixing either the oxygen fugacity or the hydrogen fugacity fixes the value of the other. Because of the same linkage, lines of constant pe $+\mathrm{pH}$ are parallel to the lines of constant oxygen and hydrogen fugacity. The upper and lower limits on the diagram $\left(\mathrm{fO}_{2}=1 \mathrm{~atm}\right.$. and $\mathrm{fH}_{2}=1 \mathrm{~atm}$.) represent the stability limits

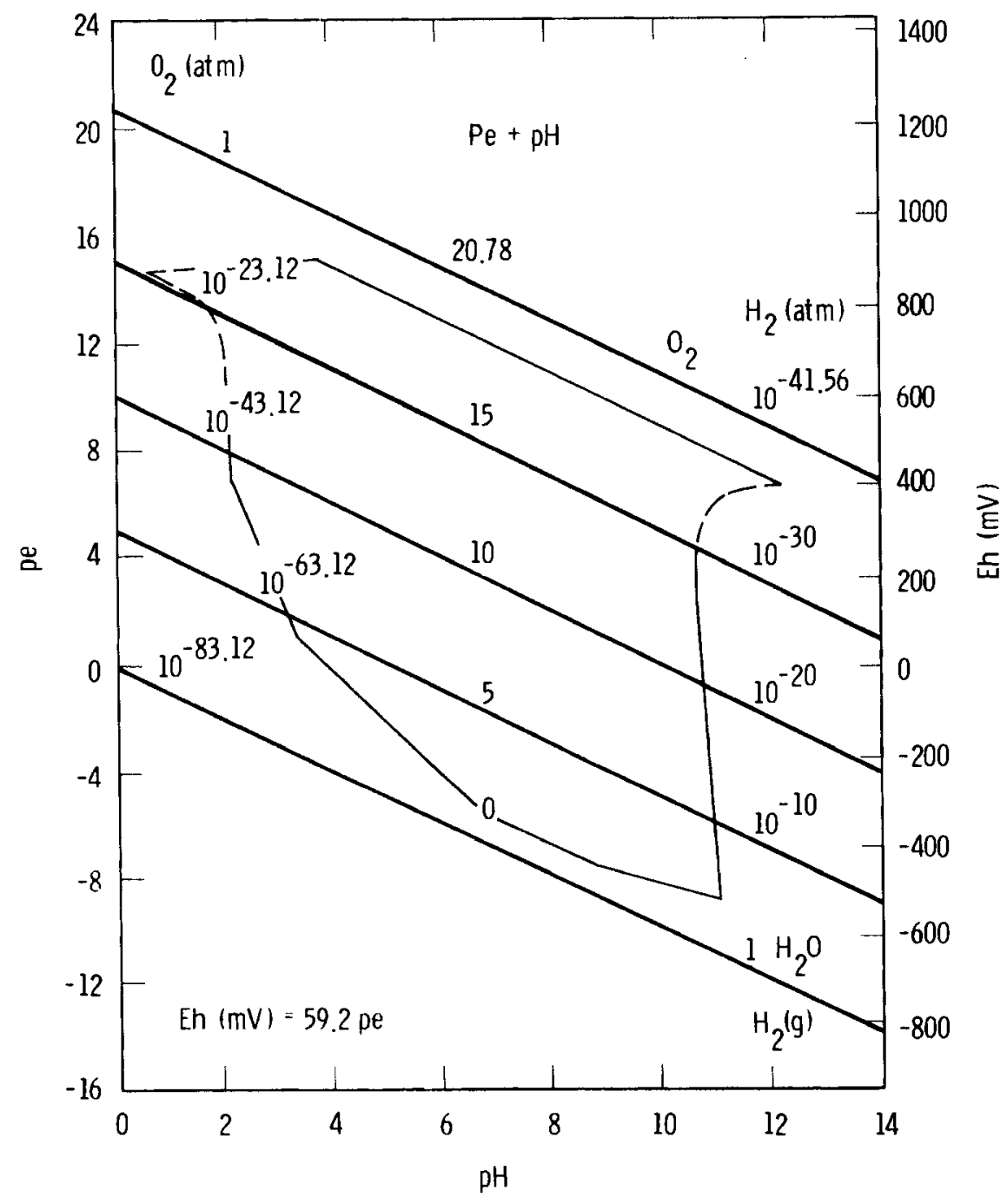

FIGURE 3.2. Comparative Measures of Redox in Natural Systems. Envelope represents range of natural waters (after Baas Becking et al. 1960) 
of water and the irregular area in the central portion of the diagram shows the approximate range of natural waters (Baas Becking et al. 1960).

\subsubsection{Methods of Measurement}

Quantification of buffering ability requires measurement of both the value to which the parameter is controlled and the capacity of the buffer. The measurement of solution $\mathrm{pH}$ under ordinary laboratory conditions is a straight forward instrumental technique; however, measurement of $\mathrm{pH}$ under conditions of elevated temperature and pressure is a somewhat more difficult problem (Taylor et al. 1979). The measurement of redox state, particularly at the low values expected in basalt (Smith et al. 1980) is a far more difficult problem. Standard electrochemical measurements of Eh are highly problematical, both because of instrumental difficulties and because of difficulties in achieving and demonstrating equilibrium under low temperature conditions (Morris and Strumm 1967). Instrumental techniques for the direct measurement of oxygen either lack the sensitivity required to detect concentrations below about $1 \mathrm{ppm}$ $\left(\mathrm{fO}_{2} \approx 10^{-6} \mathrm{~atm}\right.$ at STP) or, as in the case of the zirconia solid electrolite sensors, have not been successfully operated below about $400^{\circ} \mathrm{C}$ (Sato 1971). The direct measurement of hydrogen is an interesting possibility; however, it is hampered by the very slow achievement of equilibrium between hydrogen and oxygen under the conditions of interest. A considerable amount of work remains to be done before the oxygen-buffering ability of the backfill can be accurately defined. A variety of wet-chemical and electrochemical techniques exist for measurement of other species that may require buffering. Measurement of buffering capacity can be done either by titration or by passing solution through a known amount of buffer material and measuring concentrations in the effluent. These two methods are analogous to the batch and column experiments described in Section 3.2.2.

\subsubsection{Self-Sealing Ability}

\subsubsection{Conceptual Definition}

The self-sealing ability of a backfill is actually part of its ability to control the flow of ground water. It is considered separately because its 
major importance lies in the behavior of the backfill under accident conditions and not under normal operating conditions.

A great advantage of plastic materials such as clays is their ability to deform under stress rather than breaking or fracturing. In addition, the plasticity of certain clays such as montmorillonites (bentonites), coupled with their swelling potential, allow these clays to heal or seal any cracks or discontinuities that may develop within them. The swelling pressure developed by clays will be discussed in this section and plasticity will be discussed in the section dealing with mechanical properties (Section 3.2.8).

The swelling potential of clays and their ability to exert pressure when confined is a result of their ability to adsorb layers of water molecules between the sheets of the silicate structure. The addition of the interlayer water results in expansion of the clay crystal lattice in a direction perpendicular to the layering or along the c-axis of the crystal (Grim 1968). The swelling pressure developed by a montmorillonite clay is a function of several variables including the bulk density, water content, composition of interstitial water, and the identity of the exchangeable cations within the clay structure. Grim (1962) reported that the swelling potential of the various clay minerals decreases in the order-montmorillonite, illite, halloysite, and kaolinite. Within the montmorillonite group, swelling potential decreases when sodium within the crystal structure is replaced by other univalent, divalent, or trivalent ions.

The swelling potential and plasticity of clays result in several desirable effects in addition to self-sealing. They result in very tight contact between the backfill and the host rock and in a dense homogeneous backfill with very low permeability. In addition, the clay can, to some extent, be extruded into joints and cracks in the host rock, thus helping to seal them. This latter effect is somewhat limited by the very slow rate of extrusion of bentonite into smaller cracks. In addition, if large quantities of clay were extruded into the host rock it could signficantly reduce the swelling pressure of the backfill mass. The loss of swelling pressure would result in a significant increase in permeability. 


\subsubsection{Technical Definition}

The self-sealing ability of montmorillonite clays is strongly related to both their plasticity and their swelling potential. There is as yet no clearly defined measure of self-sealing ability, so we must at present simply describe its component parts.

An unsaturated clay, in the presence of water, will take additional water into the clay interlayers and expand to occupy an increased volume. If the clay is confined and water is available, the clay will exert a force outward on its containment, the so-called swelling pressure. The swelling pressure developed by a montmorillonite clay can, to a first approximation, be calculated as an osmotic pressure, which is due to the difference in ion concentration between the clay particles and in the bulk pore water (Pusch 1978a). The error in the calculations is small at larger interparticle distances where the bulk density is less than $1.6 \mathrm{~g} / \mathrm{cm}^{3}$. Unfortunately the range of densities of interest for backfill materials is considerably above this value. A discussion of the differences between calculated and measured swelling pressures was presented in Pusch (1978a). The swelling pressure developed by a clay may be influenced by the concentrations of the interstitial solution; however, this effect may be reduced at high clay densities.

Measured values for swelling pressures developed in Na-montmorillonite, plotted as a function of bulk density at water saturation, are shown in Figure 3.1 (Pusch 1979c). The sharp increase in swelling pressure with increasing density is related to the decrease in porosity at higher densities. Expansion into the available pore volume results in a decrease in observed swelling pressure. The smaller pore volume at higher densities allows less internal expansion and thus a higher external pressure. The measured swelling pressure curve (Figure 3.1) is nearly vertical above a water-saturated density of about $2.2 \mathrm{gm} / \mathrm{cm}^{3}$ and rises to values between 20 and $30 \mathrm{MPa}$. The curve must eventually flatten out as the effective pore volume approaches zero. However, at present the maximum possible swelling pressures are far from certain.

An alternative approach to swelling pressure is presented by Low and Margheim (1979) who measured the swelling pressure, $\pi$, of five different 
montmorilionite-water systems by determining the gas pressure required to drive inter layer water from the clay structures. The swelling pressure was found to be empirically related to the mass ratio of water to montmorillonite $\left(M_{W} / M_{m}\right)$ by the following equation:

$$
(\pi+1)=\exp \left[\alpha /\left(M_{w} / M_{m}\right)\right]
$$

where
$\alpha=$ parameter related to specific surface area of the material and cation exchange capacity (dimensionless)

Low (1979b) revised this equation to the following:

$$
(\pi+1)=\exp \alpha\left[\left(M_{m} / M_{w}\right)-\left(M_{m} / M_{w}\right)^{0}\right]
$$

where $\left(M_{m} / M_{w}\right)^{0}$ is $M_{m} / M_{w}$ at $\pi=0$.

\subsubsection{Methods of Measurement}

Very little effort has been made to directly measure the self-sealing ability of clays; however, the experiments of Pusch (1979a) inadvertently demonstrated this property by showing that bentonite-sand mixes are capable of self-sealing channels opened by high-pressure water. In addition, the selfsealing properties of clays are indirectly measured by experiments that determine their ability to self-extrude into narrow cracks or openings.

Le Bell (1978) describes an experiment to determine the swelling distance of bentonite into narrow cracks as a function of time. The cell used for this experiment is shown in Figure 3.3. The cell consists of glass plates that are mounted in a metal frame with a $0.5-\mathrm{mm}$ thick spacer placed between the glass plates. The opening between the plates acts as a simulated "crack", which is connected to a small cavity containing bentonite. The cell is immersed in synthetic ground water, and the swelling of the bentonite is recorded as a function of time. The experiment was allowed to proceed for a period of 100 hours, 


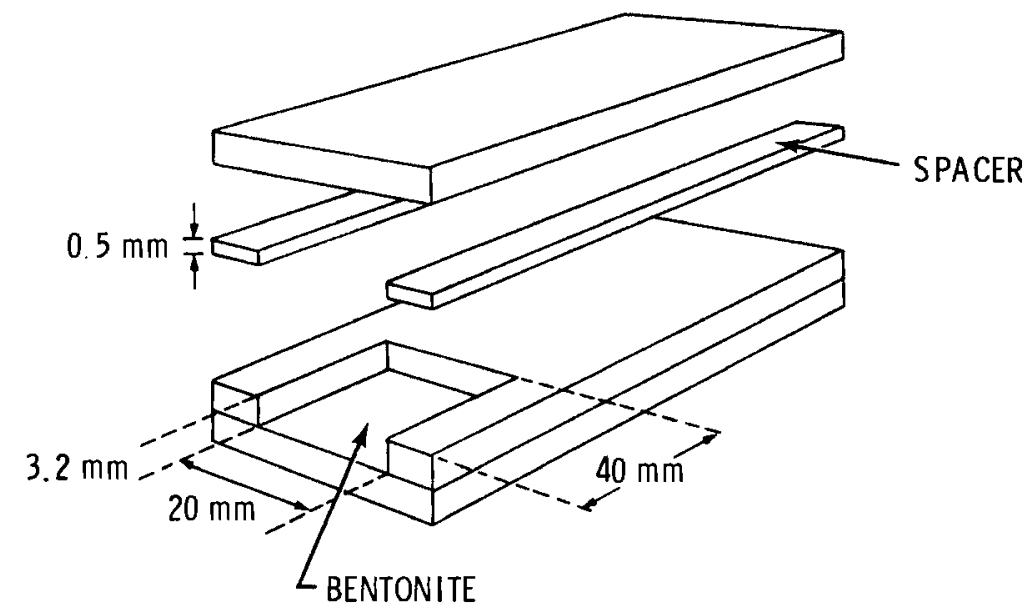

FIGURE 3.3. Cell for Measurement of Bentonite Swelling (LeBell 1978)

at which time the glass cell cracked. The advance of the clay into the crack was recorded photographically during the experiment.

Pusch (1978a) describes a laboratory experiment to determine the extrusion rates of a highly compressed bentonite. Rings with notches cut to various depths are used to form a cylindrical container for the experiment shown in Figure 3.4. The notches in the container simulate joints through which water may enter and through which bentonite is extruded. Highly compressed (50 MPa) bentonite is confined in the rigid container, and the device is flooded either with a synthetic ground water solution or a dilute saline solution. As the bentonite expands, the extusion of bentonite at various time intervals is measured by inserting a thin feeler gauge into the notches from the back side.

Swelling pressures reported by Pusch (1979c) are based on direct measurements on confined clay; however, the details of the experimental design are not reported. Low and Margheim (1979) measured swelling pressure as a function of water content. In their experiment a water-saturated paste of montmorillonite was deposited on a filter and allowed to equilibrate with a fixed pressure of water-saturated nitrogen gas. After equilibration, the filter was removed from the pressure vessel and the water content of the clay was determined. 


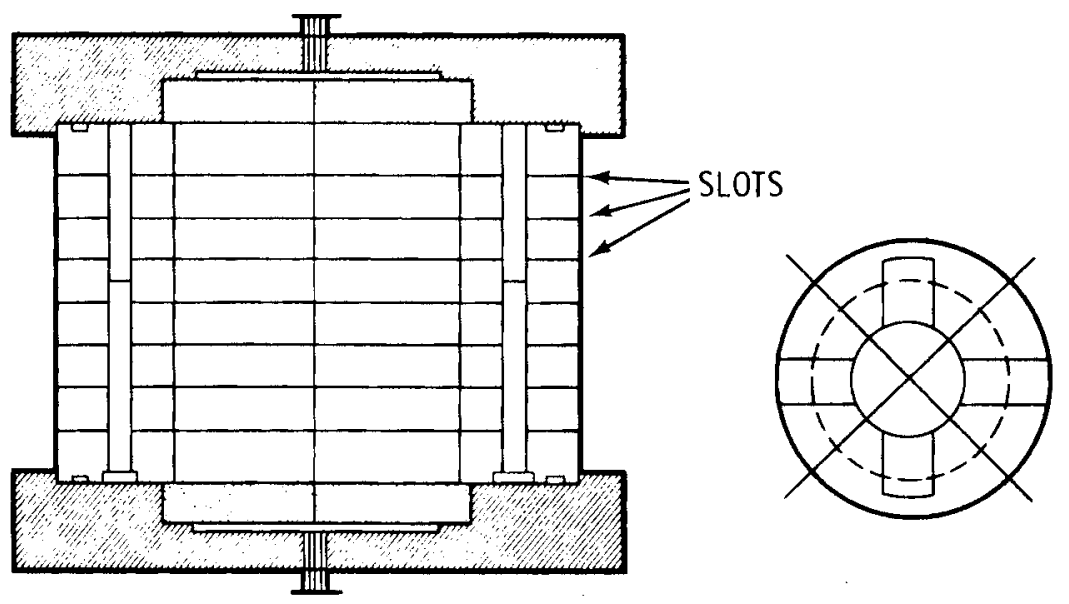
FIGURE 3.4. ASEA Atom's Device for Determination
of Extrusion Rates (Pusch 1978a)

At present a test of self-sealing ability that combines all of the various effects does not exist, but will have to be developed as part of the backfill program.

\subsubsection{Thermal Stability of Backfill Material}

\subsubsection{Conceptual Definition}

The backfill will experience a wide range of temperatures, from an initial ambient temperature to as high as $250^{\circ} \mathrm{C}$ and then a very slow return to ambient temperature as the major fission products decay and the host rock cools. The backfill must retain its functional properties throughout the thermal pulse and then continue to function for the required period of time after the repository returns to ambient temperature. Therefore, it is important that the physical and chemical properties on which the backfill attributes are based do not degrade appreciably as a result of elevated temperatures. It should be kept in mind that the effects considered in this section are reversible changes in properties resulting from variations in temperature and are distinct from the structural and chemical transformations that backfill materials may undergo during their design life (Section 3.2.9). 


\subsubsection{Technical Definition}

Temperature-induced variations in the chemical and physical properties may affect the abilities of various backfill materials to meet design requirements during the repository thermal period. Thus, it is important that the temperature variations of the properties on which the backfill attributes are based be known over the temperature range expected within the repository.

Increased temperatures will influence the ability of the backfill to exclude water because of decreased viscosity of water, increased diffusion rates, and possible changes in the swelling pressure developed within clay minerals. The affect of temperature upon swelling pressure is complicated by the fact that the interactions between clay and water will also be influenced by the externally applied pressure.

The sorption capacity of the backfill materials will be affected by changes in temperature; however direct measurements have not been made with proposed backfill materials. Sorption measurements on granite (Neternieks 1977 ) and basalt (Ames and McGarrah 1980) indicate that $K_{d} s$ for some elements (i.e., strontium) increase with increasing temperature while those for other elements (i.e., cesium) decrease with increasing temperature. Sorption measurements do not distinguish between various mechanisms for removing ions from solution, which may be relatively complex. Thus, the effects of temperature on sorption must be determined on an element by element, material by material basis.

Other important parameters that will be influenced by variations in temperature include plasticity (self-healing), heat transfer capability (thermal diffusion), ion exchange capacity and various mechanical properties such as compressive strength and shear strength.

\subsubsection{Methods of Measurement}

Because of the variety of backfill parameters affected by variations in temperature it is impossible to generalize about methods of measurements. The methods of measurement indicated for each backfill attribute must be adapted or modified to measure the property of interest over the necessary range of temperatures. 


\subsubsection{Radiation Stability}

\subsubsection{Conceptual Definition}

The ionizing radiation field associated with high-level waste may effect the performance of the backfill materials in two distinct ways. First, the radiation may directly damage or degrade the crystal structures of the component backfill materials. Second, the radiation may, through the radiolysis or breakdown of water present within the backfill and of soluble species in the water, significantly change the $\mathrm{pH}$ and oxidation state within the backfill. The first effect, that of direct radiation damage, could effect a variety of backfill attributes including water exclusion, self-sealing, sorption capacity, and thermal conductivity. Higher reaction rates, resulting from decreased crystallinity, may speed the breakdown of unstable materials within the backfill. Changes in $\mathrm{pH}$ and Eh brought about by radiolysis may effect both sorption capacity and the chemical stability of the backfill materials.

\subsubsection{Technical Definition}

The radiation field experienced by a backfill will vary strongly as a function of time and will also depend upon the performance of the overpack and canister. During the period in which the hard barriers are intact the radiation field in the backfill will be made up principally of gamma radiation. Alpha particles and most, if not all, of the beta particles will be stopped by the hard barriers. The neutron flux from reprocessed waste should be relatively small. After the hard barriers have been deteriorated and the waste form has been exposed to the leaching action of ground water, the radiation field within the backfill will include alpha and beta radiation from radionuclides either sorbed on the backfill or in solution in the interstitial fluid.

The most intense radiation field experienced by the backfill will be the early high-intensity gamma field produced by the decay of short-lived fission products. This early gamma flux decreases rapidly. After 300 years ( 10 halflives) the gamma flux from ${ }^{137} \mathrm{Cs}$, the principal gamma source among the fission products, will have decreased to approximately $10^{-3}$ of its intitial value.

The principal effect of gamma radiation in solids is ionization. Structural damage produced by gamma radiation is usually minimal in silicate 
minerals; however, high gamma doses may lead to some loss of crystallinity. The gamma field associated with the fission products, however, is coincident with the period of highest temperatures within the backfill and whatever structural damage does occur may be annealed out relatively rapidly. It is possible that decreased crystallinity may increase the reactivity of some materials and may speed the breakdown of materials that are unstable in the backfill chemical environment.

Radiolysis may, through the radiation induced breakdown of water molecules and dissolved species (i.e., $\mathrm{N}_{2}$ ), affect the $\mathrm{Eh}$ and $\mathrm{pH}$ of the aqueous phase within the backfill and within the host rock surrounding the backfill. The magnitude of the effect, which will depend upon factors such as the intensity of the radiation field, temperature, water chemistry, and mobility of radiolysis products, is uncertain at the present time; however, if the effect is large it could be important to both backfill performance and stability. Eh excursions brought about by radiolysis should not affect the stability of the major backfill components; however, they may limit the ability of the backfill to buffer Eh within the waste package. Radiolysis induced changes in pH may well affect the stability of major backfill components such as mortmorillonite clays (see Section 3.2.9).

After the hard barriers are breached the backfill will be exposed to alpha and beta radiation from both the exposed waste and from radionuclides leached out of the waste. Radiation derived directly from the waste will affect only a small volume of backfill immediately adjacent to the exposed waste. Radiation from the leached radionuclides, which will be in solution within the backfill or sorbed on the surface of backfill materials, will eventually affect the entire volume of the backfill. The radiation field resulting from leached actinides and long-lived fission products within the backfill will be considerably weaker than the early gamma field; however, it will act over a much longer period of time; and alpha particles and heavy recoil nuclei are much more effective than gamma radiation in the production of structural damage in solids. The effects of this long-term low-level radiation field will require careful evaluation, both in terms of radiation damage effects and radiolysis effects. 


\subsubsection{Methods of Measurement}

The effects of ionizing radiation on backfill materials can be evaluated either by irradiating samples and subsequently determining their physical and chemical properties or by carrying out the tests in the presence of a radiation field. The first type of testing allows determination of radiation damage effects in solids. The second type of testing allows evaluation of the effects of radiolysis. Both types of testing provide useful information and will be utilized in the PNL backfill-development program.

\subsubsection{Heat Transfer Capability}

\subsubsection{Conceptual Definition}

The backfill material must have a transfer capability sufficient to remove heat generated by the packaged waste such that package materials are maintained within temperature limitations. Without sufficient heat-removal capability, the waste temperature could become excessive and adversely affect package material integrity as well as backfill physical and chemical properties. Thus, thermal conductivity in the backfill is very important.

\subsubsection{Technical Definition}

Heat transfer capability may be defined in terms of several properties including thermal conductivity, emissivity and overall heat-transfer coefficient. Heat transfer through the waste package to the geologic medium would be expected to be via both conduction and radiation with most of the heat transfer by conduction. Radiative transfer may be significant only if air gaps are left within the waste package. Heat transfer through the backfill would be expected to be via conduction only. Radial heat transfer through an annular thickness of backfill is represented by the following equation:

$$
\underline{Q}=\frac{2 \pi K_{12} \Delta T}{\ln \frac{r_{0}}{r_{i}}}
$$


where

$$
\begin{aligned}
& \frac{Q}{L}= \text { waste heat generation per length of waste-heat generation } \\
& \text { surface }(\mathrm{w} / \mathrm{m}) \\
& \Delta T= \text { temperature drop through the backfill }\left({ }^{\circ} \mathrm{K}\right) \\
& \mathrm{K}_{12}= \text { backfill thermal conductivity }\left(\mathrm{w} / \mathrm{m}-{ }^{\circ} \mathrm{K}\right) \\
& r_{i}, r_{0}= \text { inner and outer backfill radii }(\mathrm{m}) \\
& 3.2 .7 .3 \text { Methods of Measurement }
\end{aligned}
$$

The recommended measurement would involve the use of an insulated apparatus whereby heat generated by a heater is allowed to pass through a known thickness of a solid material. By measuring power dissipation and internal and external temperatures, the thermal conductivity of the material may be calculated. Such a system may be designed to operate at elevated temperatures to simulate repository conditions. Since heat transfer through a layer of backfill would normally occur via conduction only; an overall heat transfer coefficient could be calculated with knowledge of the backfill thermal conductivity and emissivity. Emissivities would only be required to calculate radiation heat transfer as in the case when an air gap exists in the engineered barrier package design.

\subsubsection{Mechanical Stability}

\subsubsection{Conceptual Definition}

The mechanical properties of a backfill are important for its fabrication, transport and emplacement, its ability to provide mechanical support for the containerized waste, and for helping to provide the self-sealing properties of the backfill. Some mechanical properties are of significance only during the emplacement process. The backfill must retain other mechanical properties throughout the designated lifetime of the repository.

In most backfill schemes, the backfill, containing some proportion of clay, is pressed into high density blocks or other shapes that are subsequently emplaced around the containerized waste. The consolidation properties of the 
backfill materials, as a function of pressure, pressing time, water content, and backfill composition, must be known to insure emplacemnt of a backfill with the desired properties.

The mechanical-strength properties of the backfill materials are important because the preformed backfill pieces must be transported from the fabrication site and emplaced around the containerized waste without breakage or significant deformation. In addition, if the backfill is to perform as designed it is important that the containerized waste maintain a relatively fixed position within the backfill. Therefore, it is necessary to know the time dependent deformation properties of proposed backfill materials to insure that plastic flow or creep will not result in significant settling or other displacement of the containerized waste during the required containment time.

The self-sealing properties of a backfill are a result of its plasticity working in concert with its swelling properties. There is, however, a distinct trade-off between plasticity and strength. Thus, in the development of backfill materials it is important to understand both sets of properties and their relationship to insure sufficient strength for mechanical support along with maximum possible self-sealing capability.

\subsubsection{Technical Definition}

Plasticity is a dynamic property that for unconsolidated earth materials is usually defined at room temperature and pressure by the Atterberg Limits, which include the plastic limit, the liquid limit, and the plasticity index. The plastic limit is the minimum water content necessary for a soil to form a $0.32-\mathrm{cm}$ diameter roll without breakage. The liquid limit is the amount of water that must be mixed with a soil to cause the soil to deform readily with a given small stress. The range in moisture content over which the soil is plastic is equal to the liquid limit minus the plastic limit. This parameter is called the plasticity index. Index properties of this type are useful for comparative purposes but are of little direct application to the highly compacted materials required for backfills. In addition, the index properties of 
montmorillonites (bentonites) are very difficult to interpret because these materials are highly thixotropic, their shear strength being a function of time (Attewell and Farmer 1976).

Most previous work dealing with consolidation of earth materials has been concerned with either compaction resulting from natural burial of sediments or compaction of materials under construction sites. The assumption that the material is water saturated is explicit in these standard treatments and the major effect is one of forcing water out of the pore spaces in the material. Backfill materials will not be compacted in a saturated state and the principal effects will be a result of the plastic deformation of clays to fill void spaces in the material. This may be particularly significant in mixtures of clay and granular materials where the clay must deform to fill voids between the grains of the more rigid material.

Unconfined compressive strength of a clay is defined as the compressive force that is required to cause failure of an undisturbed sample tested under conditions of simple end loading. Factors that influence the unconfined compressive strength of a material include the particle-size distribution, the particle shape, the clay and non-clay mineral composition and the arrangement of particles within the material (Grim 1962). The introduction of small quantities of clay minerals into a sand acts to increase the compressive strength of the mixture, the clay acting as a cement to bind together the loose aggregate. The magnitude of this effect decreases rapidly as clay content increases and at higher clay contents it may be reversed.

The confined compressive strength, as determined in triaxial testing, is important in determining how a saturated backfill will react under mechanical stress. In these tests it is important to determine both the plastic deformation properties and the stress at which the sample fails in shear over a range of strain rates. This will allow extrapolation to low strain rates operating over long time periods. In the triaxial tests the pore pressure, which can be controlled independently, plays a significant role. The pressure developed within the pore fluid opposes the applied stress and as a result the sample sees an "effective stress" defined by 


$$
\sigma^{\prime}=\sigma-\mu
$$

where

$$
\begin{aligned}
\sigma^{\prime} & =\text { effective stress (MPa) } \\
\sigma & =\text { total stress (MPa) } \\
\mu & =\text { pore pressure (MPa) }
\end{aligned}
$$

\subsubsection{Methods of Measurement}

The determination of Atterburg limits is a standard engineering practice and the details are described ina number of books including Gillott (1968) and Attewell and Farmer (1976).

Consolidation tests are usually carried out in a consolidation cell (Oedometer), which is essentially a press with porous stone ends to allow the escape of pore water driven from the sample (Gillott 1968; Attewell and Farmer 1976). In the PNL backfill program, consolidation testing will be carried out in a standard press because the samples of interest do not contain excess pore water.

The unconfined compressive strength is measured by placing a cylindrical sample between parallel end plates. The sample is then loaded at a predetermined rate until it fails. The stress at the time of failure is the measured strength.

The confined compressive strength of a candidate backfill material can be measured in the laboratory by using a triaxial testing apparatus such as that shown in Figure 3.5. The sample to be used is sealed inside a rubber membrane and placed inside the pressure cell. A porous stone may be used as an endplate for the sample to allow regulation of the pore pressure. The sample is then subjected to a contant confining pressure in the horizontal or radial direction and an increasing axial or vertical stress until the sample fails in shear (Gillott 1968). The major principal stress is represented by the axial pressure, and the pressure in the horizontal plane represents the other principal stresses. 


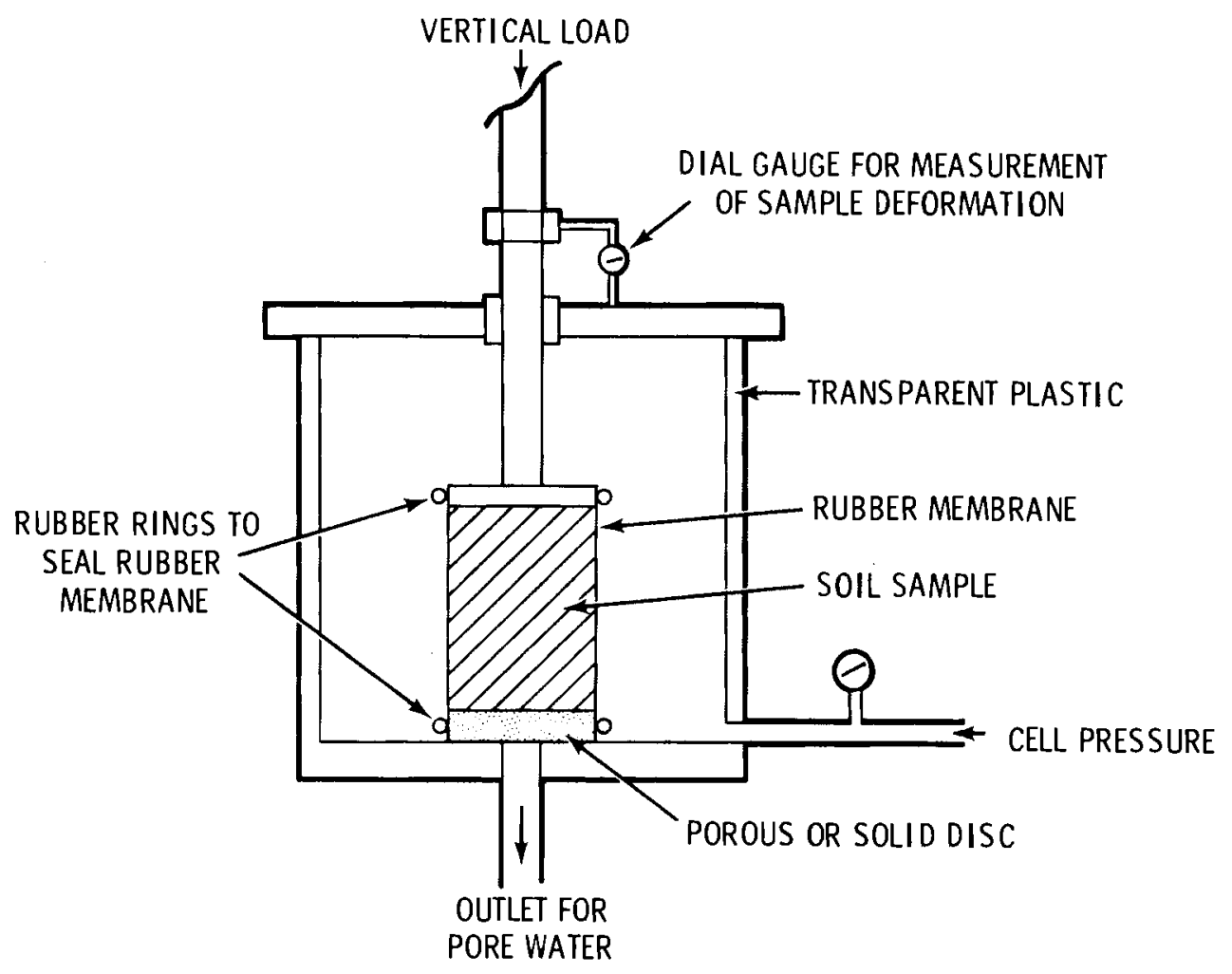

FIGURE 3.5. Schematic of Triaxial Compression Chamber (Gillott 1968)

\subsubsection{Long-Term Stability and Compatibility}

\subsubsection{Conceptual Definition}

The properties of proposed backfill materials are inconsequential if the materials will not survive under repository conditions for the required containment period. Ideally it would be preferable to use only materials or combinations of materials that are thermodynamically stable under the range of conditions expected in a repository. However, thermodynamic stability, given the low reaction rates at the temperatures of interest and the complexity of the repository chemical system, is extremely difficult to prove and its proof may be a luxury rather than a necessity. It is only necessary to give reasonable assurance that the backfill will remain in functional form for the required containment time and not that it will last indefinitely. From this perspective it is important to carefully examine the other backfill attributes and determine what portion of the backfill can degrade during the containment period without compromising its performance. 


\subsubsection{Technical Definition}

The chemical stability of the backfill materials may be limited by a number of chemical parameters including temperature, pressure, Eh, $\mathrm{pH}$, and the composition of the fluid phase in contact with the backfill. Effects that may be important include isochemical recrystallization, reactions between backfill components, reactions between backfill components and other components of the waste package, and reactions between backfill components and aqueous species transported into the backfill either from the host rock or from other waste package components.

Many of the materials under consideration as candidate backfills (i.e., clays and zeolites) are minerals formed near the earth's surface under conditions of relatively low temperature. These phases have very limited stability at elevated temperatures, and because most are hydrous, their thermal stability limits vary as a function of imposed water pressure. The effect of water pressure is strongest at water pressures below $100 \mathrm{MPa}$, which includes the range of pressures expected in geological repositories. Thus, water pressure may be an important variable in backfill stability tests.

The effect of Eh upon the major backfill components is somewhat uncertain. Most of the iron present in the montmorillonite clays (bentonites) and zeolites under consideration is present in the ferric $\left(\mathrm{Fe}^{3+}\right)$ state because of near surface origin. The iron content of zeolites is so small that there should be little effect if its oxidation state is altered. However, reduction of iron within the clays may result in some degree of structural reorganization. The effect of Eh on other proposed backfill materials must be considered on a case by case basis.

Eh values in the backfill may strongly affect interactions between the backfill and the metals of the overpack and canister. The pH strongly affects the solubilities of both silicon and aluminum and is a major determinate of the stability of silicate phases. Most silicates, quartz being a major exception, are more susceptible to dissolution or hydrolysis at low values of pH. Quartz, however, goes directly into solution as silicic acid and is much more soluble 
at high values of $\mathrm{pH}$. The stability of montmorillonite clays (bentonites) is adversely affected by both very low pH and by very high pH. Low pH favors the formation of kaolinite at the expense of montmorillonite (Garrels and Christ 1965; Helgeson et al. 1969) and very high pH, coupled with high concentrations of alkali metal or alkaline earth species, favors the formation of zeolites or feldspars at the expense of montmorillonite (Helgeson et al. 1969; Velde 1977). In adaition, $\mathrm{pH}$, acting in concert with $\mathrm{Eh}$, will control the migration of many species into the backfill.

A number of chemical reactions between backfill components and species in solution are possible. Some may serve to buffer the concentrations of species in solution; however, others may have a detrimental effect on the backfill. Clays and zeolites are both well known for their ion-exchange properties and will accept a wide variety of ionic species into their crystal structure. Both calcium and potassium will preferentially replace sodium in the montmorillonite structure with resultant changes in the properties of the clay (Grim 1968). Calcium montmorillonite, although inferior to Na-montmorillonite in swelling and plasticity, may well be an acceptable backfill component. However, introduction of potassium into the montmorillonite may bring about the formation of illite at the expense of the montmorillonite, with a serious degradation of backfill properties. Calcium is more difficult to displace than sodium and the presence of calcium in the montmorillonite may help to stabilize it against the formation of illite. In addition, other parameters, such as the concentration (activity) of silica in solution may influence the stability of backfill components. Low silica concentrations favor the formation of kaolinite at the expense of montmorillonite and silica concentration may determine what type of zeolite will be stable in the backfill.

\subsubsection{Methods of Measurement}

The problem of determining the chemical stability of proposed backfill materials under conditions expected in a repository can be approached in several ways. The stability of the materials can be determined directly from thermodynamic calculations. The stability fields of the materials can be determined through the use of experimental reversals (i.e., approaching equilibrium from both directions) under the conditions of interest. 
Relatively long-term tests under expected repository conditions, coupled with accelerated tests at higher temperatures, can be used to set limits on the amount of reaction that can occur during the containment period.

A thermochemical data base adequate for the calculation of stabilities does not exist at the present time, and it would probably require a research effort reaching well into the next century to develop the required data base. Even then there may be unacceptably large uncertainies in some of the data. The establishiment of stability fields through experimental reversals is a reasonable, or even necessary, approach in geochemical studies at higher temperatures. However, it may require several life-times of experimental effort at the temperatures of interest. The third approach, and the one adopted in the PNL backfill program, is to use experimental data to set upper limits on the amount of backfill degradation possible over the required containment times. If the material survives and performs its functions for the required time it makes little difference whether it is stable or metastable.

The keys to the third approach are the duration of the tests and the ability to detect new phases in the backfill materials at the end of the test. A hypothetical example that illustrates the magnitude of the problem is offered by an experiment that lasts for one year. If the post-test characterization indicates that no detectable reaction has occurred and the detection limit for solid reaction products is $0.1 \%$, then the most that can be said about the stability of the material is that in 1000 years less than $100 \%$ of the material will have reacted. This is not intended to imply linear reaction rates, but to set conservative upper limits on the amount or reaction possible. Test duration can be increased but not by several orders of magnitude. A major effort must be made to lower the detection limits for solid reaction products. This goal can probably be best achieved through very carful pre- and post-test characterization using the techniques of electron microscopy.

In addition to the long-term tests under expected repository conditions, accelerated tests at higher temperature will allow the determination of possible reactions and the identification of reaction products. Reaction data gathered at higher temperatures can be extrapolated to lower temperatures for comparison with test results at repository temperatures and identified reaction products $c$ an be used to seed tests at low temperatures. 


\subsection{BACKFILL MATERIALS}

\subsection{CURRENT STATE OF KNOWLEDGE}

Testing and development studies on various individual barrier components of the waste-package system have been in progress for several years. These studies have been conducted in industrial and national laboratories, as well as universities, both in this country and abroad. Most of these studies are not complete, however data generated during the past few years indicate that components of the waste-package system can prevent or minimize release of radionuclides to the natural system by functioning as effective physical and chemical barriers.

Studies and performance testing on emplacement hole backfill materials have been in progress for several years in the United States, Canada, and Sweden (Nowak 1979; Neretnieks 1977; Pusch 1977a; Sandia 1979; Fried and Friedman 1979; Nowak 1980a). The following list shows materials that have received attention:

$\begin{array}{ll}\text { Bentonites } & \text { Tachyhydrite }\left(\mathrm{CaMg}_{2} \mathrm{Cl}_{6} \cdot 12 \mathrm{H}_{2} \mathrm{O}\right) \\ \text { Quartz (sand) } & \text { Anhydrite }\left(\mathrm{CaSO}_{4}\right) \\ \text { Crushed host rock } & \text { Gypsum }\left(\mathrm{CaSO}_{4} \cdot 2 \mathrm{H}_{2} \mathrm{O}\right) \\ \text { Zeolites } & \text { Apatite }\left[\mathrm{Ca}_{5}\left(\mathrm{PO}_{4}\right)_{3}(\mathrm{OH}, \mathrm{F}, \mathrm{Cl})\right] \\ \text { Kaolinite } & \text { Pyrite }\left(\mathrm{FeS}_{2}\right) \\ \text { Attapulgite } & \text { Chalcopyrite }\left(\mathrm{CuFeS}_{2}\right) \\ \text { Iron } & \text { Bournonite }\left(\mathrm{PbCuSbS}_{3}\right) \\ \mathrm{Aluminum} & \text { Ultramarine } \\ \mathrm{CaO} & \text { Azurite }\left[\mathrm{Cu}_{3}\left(\mathrm{CO}_{3}\right)_{2}(\mathrm{OH})_{2}\right] \\ \mathrm{MgO} & \text { Borates } \\ \mathrm{Al}{ }_{2} \mathrm{O}_{3} & \text { Charcoal } \\ \mathrm{CaCl}{ }_{2} & \text { Peat } \\ \mathrm{PbO} & \text { Mixtures of the above } \\ \text { Recent studies in the United States (Nowak 1979; Sandia 1979) have focused } \\ \text { he testing and development of smectite clay and sand barriers for use in a } \\ \text { repository. Screening studies have been completed on various clays, }\end{array}$


natural soils, and zeolites as a function of solution salinity, pH, flow rate, and temperature. The sorptive capacities for europium, plutonium, americium, cesium, and strontium in brine have been measured for smectite clay (hectorite and bentonite/montmorillonite) and sand mixtures. Plutonium and americium sorb very well ( $K_{d}$ values about $2000 \mathrm{ml} / \mathrm{gm}$ ) and europium, cesium, and strontium sorb moderately $\left(K_{d}\right.$ values about $\left.200 \mathrm{ml} / \mathrm{gm}\right)$. Existing data (Nowack 1979; Sandia 1979; Nowak 1980a, 1980b) suggest that a properly chosen, 0.3-m-thick backfil1 barrier surrounding a waste container could delay the breakthrough (defined as one percent of initial concentration) of plutonium and americium through the barrier for periods of 10,000 to 100,000 years depending upon the interstitial brine flow rate. Concurrently, the breakthrough of cesium, strontium, and europium could be delayed for 1,000 to 10,000 years, which is sufficient time for nearly complete decay of those radionuclides. Backfill studies in Sweden (Neretnieks 1977; Pusch 1977a; DOE 1979) on bentonite clay, clay/sand mixtures, and barriers of the zeolite mineral clinoptilolite yield similar results: a 0.2-m backfill barrier of clinoptilolite could delay the breakthrough of cesium and strontium in ground water for about 10,000 years; a 1-m thick clay/sand mixture could delay the release of plutonium and neptunium for about $2,000,000$ years.

Other ongoing programs (PNL 1978; Komarneni and Roy 1979) are generating additional data for backfill barrier utilization. One activity (PNL 1978) involves testing the radionuclide sorptive behavior of various rocks and minerals. Sorption has been shown to be an important potential barrier to nuclide transport (Nowak 1980a). The sorptive capacity of several minerals for anionic radioactive chemical species, such as iodine and technetium, is also being studied (Fried and Friedman 1979) along with the increased sorption of technetium under reducing conditions (Ewing and Haaker 1979). Others are studying related waste/rock interactions under high-temperature high-pressure aqueous conditions (Komarneni and Roy 1979) and providing sorptive capacity information for various shales and clay minerals.

Currently available data on emplacement hole backfill barrier performance (Nowak 1979; Neretnieks 1977; Nowak 1980a; DOE 1979) particularly in regard to radionuclide sorptive characteristics, indicate that backfill materials can effectively contribute to the isolation of radioactive wastes in a geologic 
repository in the presence of brines and other ground waters. Further work on these backfill barriers is in progress (Jenks 1979; Nowak 1979; Sandia 1979; Nowak 1980a, 1980b; EPRI 1979) for better characterization and engineering deve lopment.

\subsection{BACKFILL SCREENING}

On the basis of a review of the literature and of consideration of the required attributes and performance criteria for backfill materials, it was possible to reduce the list of backfill materials presented in Section 4.1 to a considerably shorter list of materials for initial consideration in the backfill development program. The shorter list of preferred candidate backfill materials is presented in Table 4.1. It should be emphasized that this represents an initial list for testing purposes and that other materials can and will be added as the need to do so is indicated by testing and evaluation. In the remainder of this section a brief discussion of major candidate materials is followed by a brief discussion of each attribute.

\subsubsection{Sodium Bentonite/Sand Mixtures}

Bentonite/sand (quartz) mixtures have been the object of intensive study in both Sweden and the United States. The two materials have widely divergent properties and properly chosen mixtures of the two materials possess the desirable properties of both materials. For example quartz sand can contribute high-bearing strength and high-thermal conductivity to the mixture and the bentonite can contribute low-permeability, high-sorption capacity, and selfsealing ability. The properties of bentonite and quartz sand are summarized in Table 4.2 .

The bentonite recommended for use in backfill materials by the Swedish program is a floculated/sodium bentonite (Volclay $M \times 80$ ) with a size distribution 0.07 to $0.08 \mathrm{~mm}$. The sand recommended for use with the bentonite is quartz sand $\left(98 \% \mathrm{SiO}_{2}\right)$, sized 0.063 to $2 \mathrm{~mm}$. To possess good bearing capacity, thermal conductivity, and low permeability, the quartz/bentonite fractions should be mixed in proportions that allow the compressed bentonite to fill the pore space in a continuous sand matrix without appreciable swelling. 
TABLE 4.1. Preliminary List of Candidate Backfill Materials

- Clays

- Sodium bentonite

- Calcium bentonite

- Illite

- Treated sodium bentonite

- Zeolites

- Clinoptilolite

$-13 x$

- Zelon 900

- Metal Powders or Fibers

- Iron

- Aluminum

- Lead oxide

- Minerals/Rocks

- Pyrite

- Ferrosand (glauconite)

- Quartz Sand

- Basalt

- Tuff

TABLE 4.2. Main Advantages(a) and Disadvantages of Bentonite/Quartz Material

\begin{tabular}{lcc}
\multicolumn{1}{c}{ Feature } & Quartz Material & Bentonite \\
\cline { 1 - 1 } Long Time Stability & + & + \\
Bearing Capacity & + & - \\
Plasticity & - & + \\
Permeability & - & + \\
Swelling Properties & - & + \\
Heat Conductivity & + & - \\
Ion Exchange Capacity & - & +
\end{tabular}

(a) Advantages are indicated by a +; disadvantages by a -.

Permeability tests have been conducted by the Swedish KBS (Pusch 1979b) on low-density $\left(\rho \sim 1.8 \mathrm{gm} / \mathrm{m}^{3}\right)$ clay-poor bentonite/quartz backfill mixtures at moderately high hydraulic gradients. These tests were designed to test 
mixtures for use as room backfills. Materials consisting of about $4 \%$ sodium bentonite and about $8 \%$ sodium bentonite were studied. The average nydraulic conductivities for these materials at a hydraulic gradient of approximately 100 is $3 \times 10^{-4} \mathrm{~cm} / \mathrm{sec}$ for the $4 \%$ mixture and $1.5 \times 10^{-5} \mathrm{~cm} / \mathrm{sec}$ for the $8 \%$ mixture. When compared with the permeability for a $20 \%$ mixture $\left(\sim 10^{-7} \mathrm{~cm} / \mathrm{sec}\right)$, these values indicate the effect of bentonite content on permeability. Permeability measurements carried out on highly compacted sodium bentonites by Kharaka and Smalley (1976) indicated hydraulic conductivities on the order of $10^{-13} \mathrm{~cm} / \mathrm{sec}$.

The clay-poor materials tested were found to be much less effective as sealing substances than the $20 \%$ bentonite mixture (Pusch 1979a). Local piping is more easily produced when the clay content of the backfill material is low. The piping observed in the KBS testing, however, did not appear to form permanent highly permeable passages in the material. It was concluded, on the basis of this testing, that the sodium bentonite content should be a minimum of $10 \mathrm{wt} \%$ for the particular sand grain size distribution used for the tests. In addition, a series of tests were performed to determine the extent of channeling or piping in a $20 \%$ sodium bentonite mixture. The tests showed that high hyaraulic gradients are required to yield piping in the material. When local piping did occur in the tests, self-sealing took place as a result of the swelling of the bentonite. Tests results (Pusch 1979a, 1979b) showed that Darcy's Law was not obeyed under the conditions of the tests; however, reasons for the deviation are unclear.

\subsubsection{Natural and Synthetic Zeolites}

The primary incentive for using zeolites is their enhanced ion-exchange capability. Zeolites display a low mechanical strength and do not have the sealing capabilities of the swelling clays. Zeolites might be used as a thin outer backfill layer surrounding an inner layer of swelling clay. An outer layer of sodium zeolite would protect the inner clay from $\mathrm{K}^{+}$and could prevent washing away of clay along the backfill margins. In a recent study radionuclides expected in a waste repository were ranked in order of hazard (Barney and wood 1977). Some of the highly ranked nuclides such as ${ }^{129} \mathrm{I},{ }^{99} \mathrm{Tc},{ }^{237} \mathrm{~Np}$, and ${ }^{226} \mathrm{Ra}$ are not well sorbed on swelling clays. Silver or lead zeolites can 
be used to trap ${ }^{129} \mathrm{I}$, and, with proper redox control, ${ }^{99} \mathrm{Tc}$. However, little is known of their stability in repository environments.

A number of natural and synthetic zeolites, including mordenite, phillipsite, chabonite, clinoptilolite, erionite, onaline, and "13x", have been studied in Sweden (Neretnieks 1977). U.S. studies have included Clinoptilolite and Mordenite (Nowak 1980b). Potassium ions released from zeolites through ion exchange may promote the conversion of montmorillonite to illite. Thus, the sodium or calcium zeolites are preferable for use in backfills.

\subsubsection{Powdered Metals and Graphite}

Graphite is a useful backfill material to choose for the moderation of oxygen fugacity in the repository; however, the kinetics of the oxidation reaction may be relatively slow at repository temperatures. It has good thermal conauctivity qualities and aids in the transport of neat through the backfill.

Aluminum, like graphite, is a good thermal conductor. Its oxidation should help to lower $\mathrm{fO}_{2}$ immediately after closure of the repository and its oxidation products should help to buffer $\mathrm{pH}$ in an intermediate range. In addition, the oxidation products occupy more volume than the metal and thus will add to the swelling pressure of the clays. The oxidation products may react with cations from the ground water to form additional clay within the backfill.

Iron within the backfill would also aid thermal conductivity of the backfill and oxidation would help to lower the oxygen fugacity within the waste package. However, formation of hydrous iron oxides may tend to depress the pH and iron may react with the clays in the backfill, adversely affecting their properties.

\subsection{PRIOR DATA AND TESTING}

\subsubsection{Water Exclusion}

Hyaraulic conductivities for highly compacted sodium bentonites have been reported by Kharaka and Smalley (1976), and their results are shown in Figure 4.1. Pusch $(1979 \mathrm{c})$ presented a diagram relating hydraulic conductivity to water saturated density of sodium Dentonite (Figure 4.2 ). There is little data 


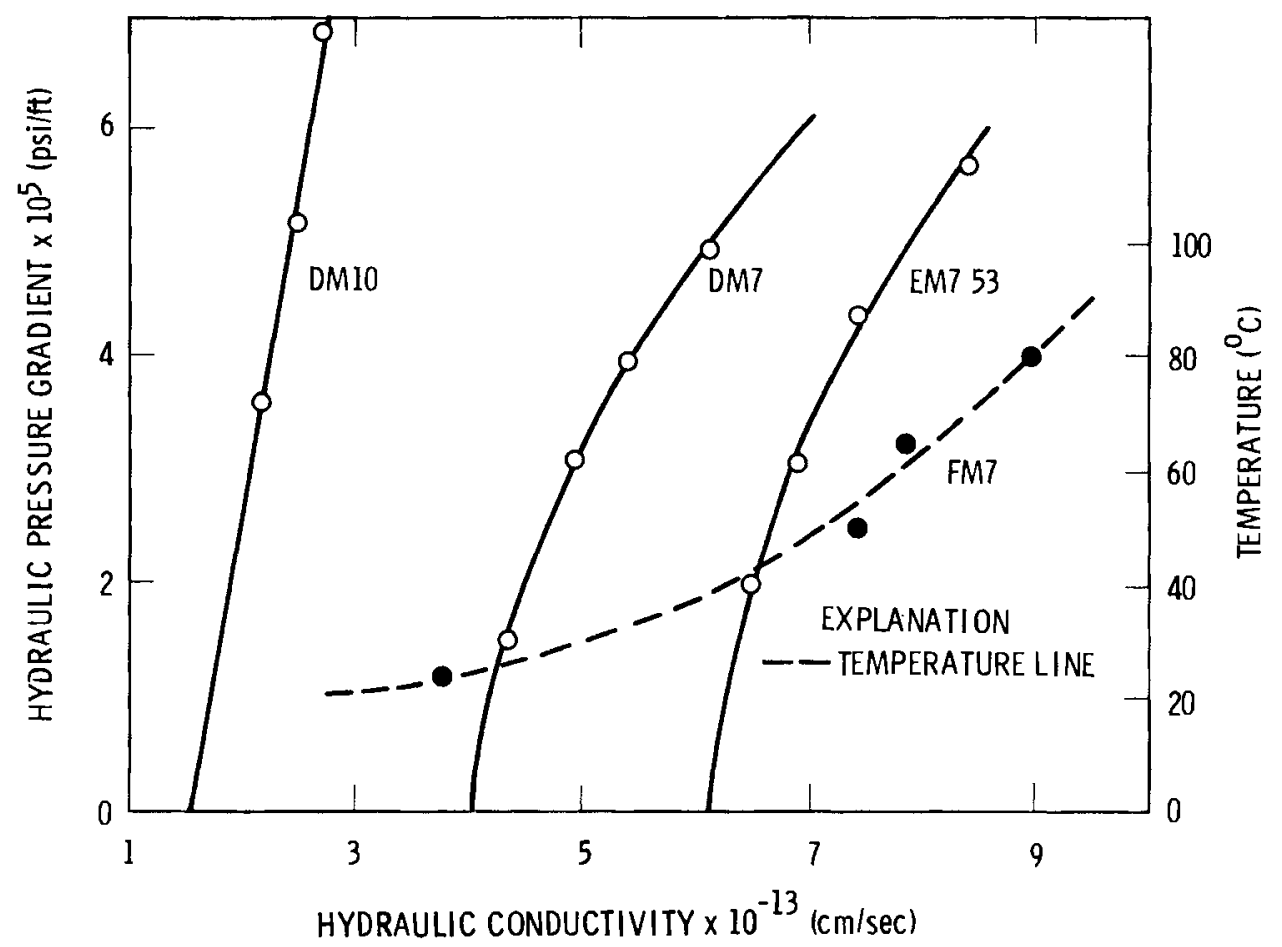

FIGURE 4.1. Hydraulic Conductivity Plotted Against Pressure Gradient for Samples of Compressed Sodium Bentonite (DM 10, DM7, and EM-7-53). Broken line (FM 7) is plot of hydraulic conductivity against temperature (after Kharaka and Smalley 1976)

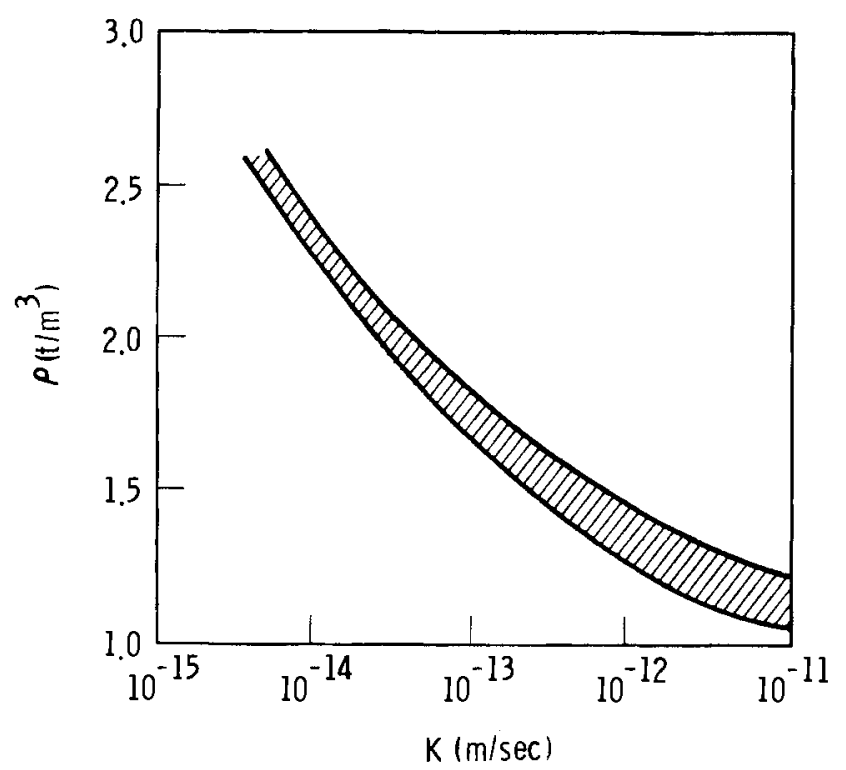

FIGURE 4.2. Relationship Between Water-Saturated Density $(\rho)$ and Hydraulic Conductivity $(K)$. A band is shown to allow for variation resulting from changes in water chemistry and experimental error (after Pusch 1978b) 
in the literature that relates directly to repository conditions; however, Kharaka and Smalley (1976) report that the increase in hydraulic conductivity observed at temperatures up to $65^{\circ} \mathrm{C} \mathrm{c}$ an be explained by decreases in the viscosity of water.

\subsubsection{Sorption Capability}

The major effort in the U.S. to date has been performed at Sandia Laboratories and is described by Nowak (1980a, 1980b). $K_{d}$ measurements have been carried out principally with sodium bentonite, hectorite, clinoptilolite and kaolin, including mixutres of these materials with quartz sand. Radioisotopes tested were ${ }^{152} \mathrm{Eu},{ }^{238} \mathrm{Pu},{ }^{243} \mathrm{Am},{ }^{137} \mathrm{Cs},{ }^{85} \mathrm{Sr}$, and ${ }^{99} \mathrm{Tc}$. Most of the measurements were made using a batch technique. Some ${ }^{152} \mathrm{Eu}$ measurements were made in a flowing system. In all experiments, the solution used was one of two brines. Brine $A$ represents the composition of fluid inclusions within the WIPP salt, and Brine $B$ represents a solution of bulk WIPP salt in water.

Some key results from batch $K_{d}$ measurements for ${ }^{152} \mathrm{Eu}^{3+}$ are summarized in Appendix A. Relatively high values were measured in dilute brines. The more concentrated brine gave lower values in montmorillonite and mordenite (a natural zeolite) but higher values in hectorite. Typical $k_{d}$ values for ${ }^{238} \mathrm{Pu}_{\text {(IV) }}$ and ${ }^{243} A m$ (III) sorption on samples of commercial clays are also summarized in Appendix $A$. No significant sorption of ${ }^{85} \mathrm{Sr}$ or ${ }^{99} \mathrm{TcO}_{4}$ was observed on bentonite or hectorite. Tests with activated charcoal indicated $k_{d} s$ of 290 to 380 for ${ }^{99} \mathrm{TcO}_{4}$ in Brines $A$ and $B$. Values of $K_{d}$ for ${ }^{137} \mathrm{Cs}$ were quite low $(1.6$ to 4.9) indicating that the clays studied would not be effective sorption barriers for cesium in concentrated brines.

Sorption work in Sweden has focused on crystalline rocks with both highand low-ionic strength ground waters. The chemistry of the ground waters used as well as the results for three nuclides (Neretnieks 1977) are given in Appendix A. Note that comparison of data gathered at $20^{\circ}$ and $70^{\circ} \mathrm{C}$ show no clear trend in $k_{d} s$ with increasing temperature, with an increase in $k_{d}$ for strontium but a decrease for cesium.

In backfills with very low hydraulic conductivities, the transport of material through the backfill may be dominated by diffusion through the 
interstitial water. The rate of diffusion through the backfill will depend on normal diffusion processes and on the sorption properties of the backfill materials. Sorption will produce a retardation effect for diffusion very similar to that produced for flow transport.

Some diffusivity experiments have been performed to reassess the effective diffusivity of nuclides in beds of backfill materials (Neretnieks 1977). The apparatus used consists of a Teflon block with a cavity for containing the backfill material covered with a glass filter. The apparatus is placed in another stirred glass vessel containing solution. Penetration into the bed as a function of time was measured for $\mathrm{Sr}^{2+}$ in $10 \%$ bentonite/sand and clinoptilolite. Diffusivities of $1.1 \times 10^{-10} \mathrm{~m}^{2} / \mathrm{sec}$ and $1.3 \times 10^{-10} \mathrm{~m}^{2} / \mathrm{sec}$ were observed in clinoptilolite and $10 \%$ bentonite, respectively.

Unfortunately most of the published diffusion data for clays is for clays in a dispersed or colloidal state and may not be directly applicable to highly compressed clays. There is a great need for laboratory determination of diffusion rates of radionuclides and common ground-water ions through highly compacted clays under the range of temperatures expected in a repository.

\subsubsection{Control of Eh and $\mathrm{pH}$}

Data on redox and pH environments of backfill materials is especially prolific as related to mineral stability, ion-exchange properties, and swelling properties. Literature sources mentioned under these separate attributes are also sources for such data as supporting independent variables. Good sources of data on mineral stability in terms of redox and $\mathrm{pH}$ are Lindsay (1979) and Garrels and Christ (1965).

\subsubsection{Self-Sealing Ability}

Pusch (1979c) reports an experimentally derived curve relating the swelling pressure developed in a confined sodium bentonite to the density at water saturation. This curve, (see Figure 3.1), indicates that swelling pressure increases exponentially as a function of density and that swelling pressures in excess of $10 \mathrm{MPa}$ can be achieved with highly compacted bentonites. 
In the clay-swelling experiment described by LeBell (1978), a curve was developed which showed the distance $M X-80$ bentonite penetrated into a narrow crack as a function of time. Figure 4.3 shows this curve that illustrates the initial rapid swelling and the decrease of rate of clay swelling to a constant value as the bentonite approached equilibrium. LeBell (1978) concluded that the swelling pressure of wet bentonite is due to the disjoining pressure in the thin films of water between the lattice layers of the clay. The swelling pressure of the bentonite is largely governed by the ionic strength and cationic charge of the electrolyte between the montmorillonite platelets. Responding to a given external pressure, the bentonite clay will swell until the disjoining pressure in the thin films of water is equal to the external pressure. For example, if bentonite is maintained in contact with ground water and is allowed to swell freely, the clay will continue to swell until the pressure within the clay is equal to the pressure of the ground water.

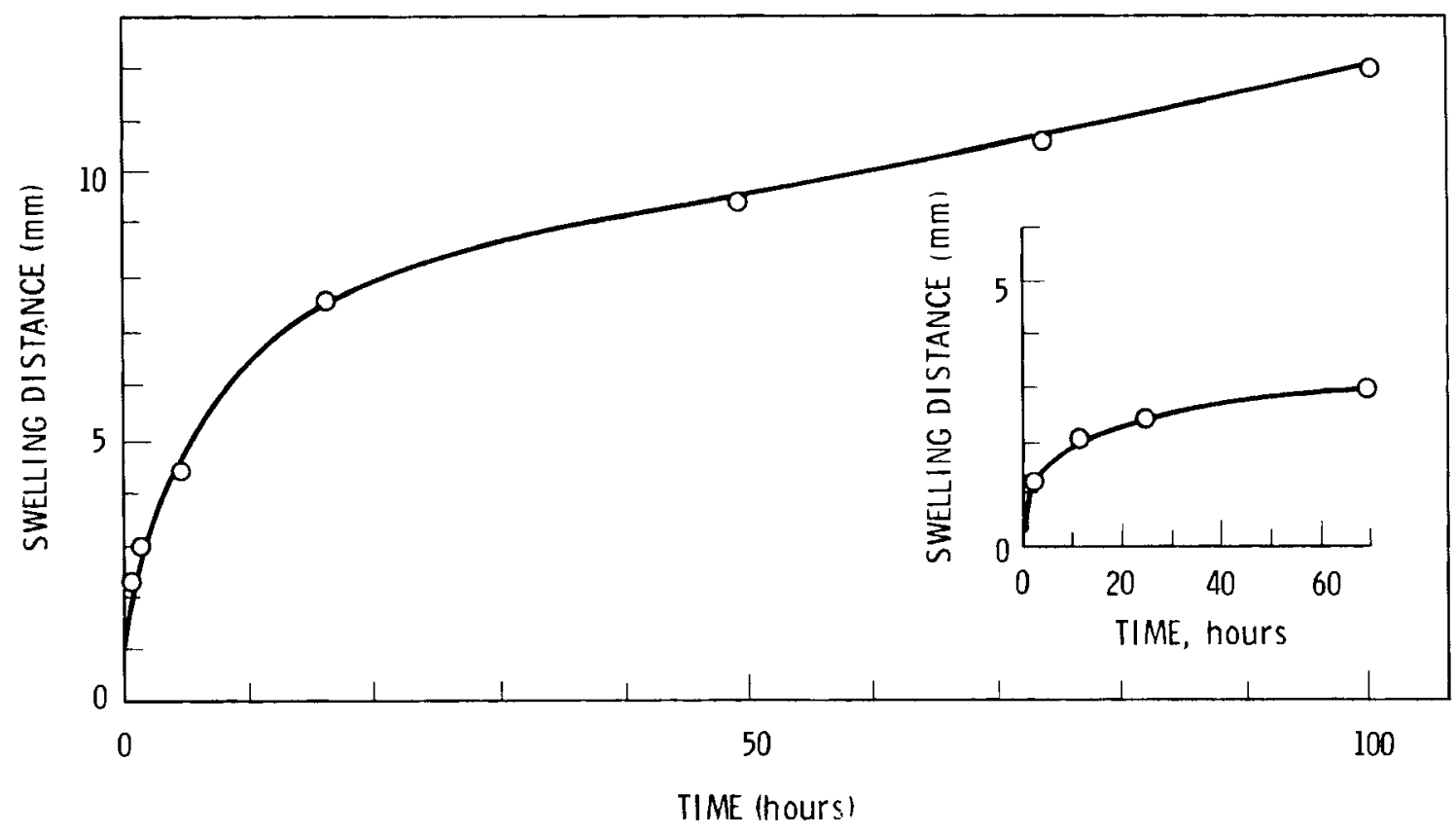

FIGURE 4.3. Swelling of Compacted Bentonite Into Space Between Parallel Plates Separated by $0.5 \mathrm{~mm}$. Inset represents swelling of bentonite into crack that developed in glass cover plate after 100 hours (LaBelle 1978) 
From his experiments to determine the rate of extrusion of wet expanding bentonite, Pusch (1978a) concluded that, in narrow joints less than $1 \mathrm{~mm}$ wide, the rate of bentonite extrusion is very slow except for the first few centimeters of movement which may take place in a few months times. Secondly, it was determined that the swelling pressure of the extruded bentonite declines rapidly with distance from the disposition hole. He calculated, for example, that at 10 to $20 \mathrm{~cm}$, the swelling pressure of the bentonite is less than onethird of that pressure in the deposition hole. As a result of the study he concluded that the extrusion of dense bentonite will probably not exceed 10 or $20 \mathrm{~cm}$ in very narrow joints even after thousands of years.

\subsubsection{Radiation Stability}

The maximum cumulative dose and dose rate (gamma) to the inner surface of a backfill material surrounding a steel clad waste package containing a standard spent fuel bundle versus time is given in Table 4.3 (DOE 1979).

Most of the literature on radiation damage deals with either reactor materials or waste forms. Very little information is available that pertains directly to potential backfill materials. Corbett and others (1963) reported minor changes in the degree of crystallinity, particle size, and ion exchange of kaolinite as a result of large gamma doses. Spitsyn and others (1980) report little or no effect of large gamma doses on quartz and results similar to those of Corbett and others (1963) for kaolinite. Swyler and others (1980) report formation of colloidal sodium metal in halite as a result of irradiation.

TABLE 4.3. Maximum Radiation Dose and Dose Rate (DOE 1979)

\begin{tabular}{|c|c|c|}
\hline Time (Years) & Dose Rate $(\mathrm{R} / \mathrm{Hr})$ & Cumulative Dose $(R)$ \\
\hline 10 & $4 \times 10^{4}$ & $5 \times 10^{9}$ \\
\hline 100 & $5 \times 10^{3}$ & $18 \times 10^{9}$ \\
\hline 500 & $1 \times 10^{1}$ & $23 \times 10^{9}$ \\
\hline 1000 & $4 \times 10^{-1}$ & $23.01 \times 10^{9}$ \\
\hline
\end{tabular}




\subsubsection{Heat Transfer Capability}

The thermal conductivity of the backfill is a very important parameter because it will, to a large extent, control the temperature of the waste package. This was realized early in the Swedish program and was one of the main reasons for suggesting a high quartz and a low bentonite content for the backfill (Pusch 1977b). The general relationship is that thermal conductivity increases with increasing degree of water saturation. A $10 \%$ bentonite mixture will take up water to equilibrium corresponding to a water content of about $20 \%$ to $30 \%$ at water saturation provided that no swelling takes place. In the dry condition, the thermal conductivity has been found to be at least $0.5 \mathrm{w} / \mathrm{m}-{ }^{\circ} \mathrm{C}$. When fully saturated, the thermal conductivity is at least 2 to $3 \mathrm{w} / \mathrm{m}-{ }^{\circ} \mathrm{C}$. As bentonite content of the mixture is increased, thermal conductivity decreases.

Commercial hectorite (10\%) mixed with quartz in the dry state was found to have a thermal conductivity comparable to that of $10 \%$ bentonite/quartz mixtures. The thermal conductivity of salt was found to be somewhat higher at about 3 to $4 \mathrm{w} / \mathrm{m}-{ }^{\circ} \mathrm{C}$ (Gera 1972).

\subsubsection{Mechanical Stability}

The Atterberg Limits for bentonites are larger than those for illite or kaolin clays. The exchangeable cation associated with the clays also affects the value of the Atterberg Limits. The sodium bentonites show higher plastic 1 imits and liquid limits than the calcium bentonites. Grim and Guven (1978) state that the high plastic and liquid limit for sodium bentonites make this clay a difficult material for engineering purposes because of the properties of shear strength, compaction, etc. Due to the variation of the Atterberg Limits with the nature of the exchangeable cation, a change in the chemical or physical environment of the clays after emplacement could lead to significant changes in physical properties.

Pusch (1977a) conducted a study of the influence of cementation on the properties of a clay/sand backfill materials. He concluded that cementation has an important effect upon the mechanical properties of fine-grained soils. Simple shear tests were conducted upon cemented and noncemented sand to determine the stress/strain relationships for the two types of materials. The sand 
in these tests is representative of the matrix in the sand/bentonite mixtures. Figure 4.4 shows the results of these tests. A non-cemented densely layered sand reached a maximum shear stress in connection with a volume increase. This result indicates that if a very dense material is selected for use as a backfill material, shear strain will probably not cause the backfill to decrease in volume. In addition, Pusch (1977a) showed that a noncemented backfill material exhibits plastic behavior. Thus, a change in the stress forces that are applied to noncemented backfill materials will produce permanent deformation instead of cracks and fissures.

Skempton (1953) plotted curves showing the relation between the void ratio and the effective overburden pressure for silts and clays. The decrease in void ratio produced by increasing overburden pressure is shown in Figure 4.5 . He found a correlation between field and laboratory test results. However, field samples collected at great depth show a more rapid decrease in void ratio than laboratory samples exposed to the same pressure.

Compressibility is the relationship between the increase of the unit load on a laterally confined sample and the decrease of its void ratio. Sodium bentonite, for example, has a large reduction in volume with only a small pressure application. Kaolinite and illite are both less compressible than bentonite.

Samuels (1950) studied the rate of consolidation of clays with time, given a specific consolidation load of four to eight tons per square foot. The curve in Figure 4.6 shows this relationship. Bentonites exhibit a slower

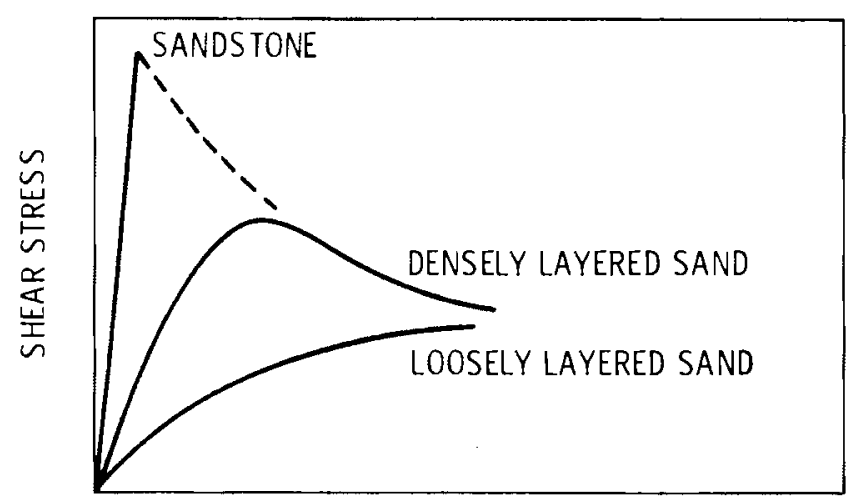

SHEAR STRAIN
FIGURE 4.4. Stress/Strain Relationships in Simple Shear Tests for Noncemented and Cemented Sand ("Sand" and Sandstone," respectively) (Pusch 1977a) 


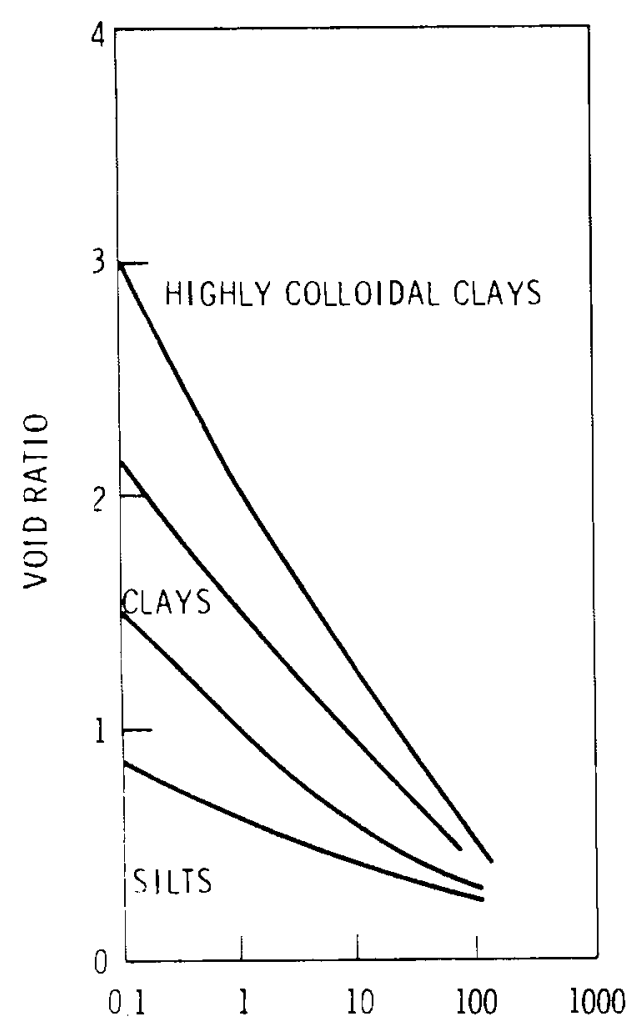

EFFECTIVE OVERBURDEN PRESSURE $\left(\mathrm{kg}^{\prime} \mathrm{Cm}^{2}\right)$
FIGURE 4.5. Approximate Relationship Between Void Ratio and Overburden Pressure (Skempton 1953)

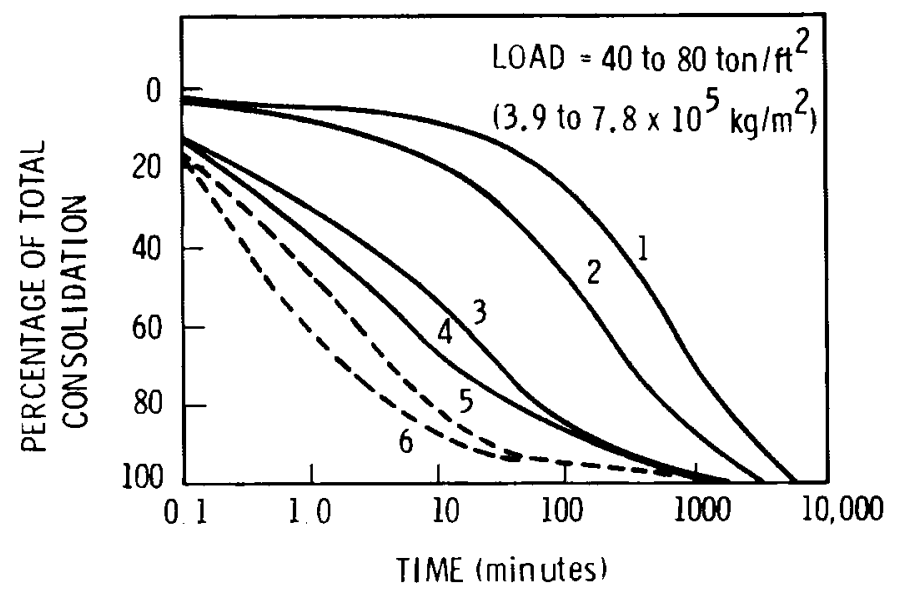

FIGURE 4.6. Rate of Consolidation of Modified Kaol ine and Wyoming Bentonite (Samuels 1950)

1. Natural (sodium)

2. Calcium

3. Aluminum

Bentonite

4. Thorium

5. Calcium

6. Sodium

Kaol in

initial rate of consolidation, but the rate increases with time. With increasing loads, the rate of consolidation for bentonites decreases initially and then has little effect. For kaolinite, the rate ofconsolidation of the material is directly proportional to the load applied. 
In clays, unconfined compressive strength is the compressive force required to cause failure of an undisturbed sample tested under unconfined conditions. The unconfined compressive strength of a material is dependent upon the size and shape of voids and grains. Table 4.4 shows the compressive strength of sand and clay mixtures according to Mielenz and King (1955). The data indicate that the introduction of small amounts of clay to the soil mixture increases the compressive strength of the substance. The sodium bentonite clays have a compressive strength of about $0.38 \mathrm{MPa}$, while kaolinite has a value of $0.69 \mathrm{MPa}$.

Shear strength is determined under conditions of increasing load pressure upon a sample. The shear strength is measured by the shearing stress at maximum displacement before failure (Grim and Guven 1978). Shear resistance of earth materials depends upon the amount of clay and nonclay components of the material, the moisture content, the load upon the material, and the ability of a material to drain contained water and expel air as a response to load, and the rate at which the load is applied.

TABLE 4.4. Compressive Strength of Sand and Clay Mixtures (Mielenz and King 1955)

\begin{tabular}{|c|c|c|c|c|c|c|c|}
\hline & & & Moist Sp & cimens & Air-L & ried $\mathrm{S}$ & ecimens \\
\hline Mixture, & by Wei & & & & & & \\
\hline $\begin{array}{l}\text { Montmo- } \\
\text { rillonite }(a) \\
\end{array}$ & $\begin{array}{l}\text { Kaolin- } \\
\text { ite (b) }\end{array}$ & $\underline{\text { Sand }}$ & $\begin{array}{c}\text { Content, }(c) \\
\text { wt } \%\end{array}$ & $\begin{array}{c}\text { Strength, } \\
\text { psi }\end{array}$ & $\frac{\text { Contel }}{\text { Initial }}$ & $t, \%$ & $\begin{array}{c}\text { Strength, } \\
\text { psi }\end{array}$ \\
\hline 100 & & & 17.1 & 55.5 & 20 & 7.0 & 195.2 \\
\hline 25 & & 75 & 14.4 & 42.0 & 18.1 & 1.3 & 541.0 \\
\hline 25 & 25 & 50 & 13.9 & 85.5 & 19.6 & 2.6 & 533.5 \\
\hline & 25 & 75 & 13.6 & 9.1 & 17.8 & 0.1 & 76.5 \\
\hline & 100 & & 14.2 & 100.3 & 17.8 & 0.4 & 65.6 \\
\hline
\end{tabular}

\footnotetext{
(a) Sodium montmorillonite from Osage, Wyoming.

(b) Kaolinite by Bath, SC (well crystallized and fine grained).

(c) Optimum moisture content for strength.
} 


\subsubsection{Long-Term Compatability and Stability}

Data concerning the chemical stability of candidate backfill materials falls into two general categories, data gathered at room temperature and data gathered at high pressure $(\mathrm{P} \geq 100 \mathrm{MPa})$ in hydrothermal tests.

Data presented in Tables 4.5 and 4.6 are taken from Grim (1968) and Velde (1977), respectively. Note in Table 4.5 that montmorillonite in its sodium form retains its high cation-exchange capacity at elevated temperatures much better than do calcium and lithium forms. Loss of cation-exchange capacity at elevated temperature is accompanied by a decrease in swelling and the ability to absorb water in interlayer positions. Table 4.6 shows that the sodium and calcium forms undergo thermal decomposition at higher temperatures than the potassium forms.

TABLE 4.5. Cation Exchange Capacity of Montmorillonite as a Function of Temperature (Grim 1968)

Temperature

\begin{tabular}{ccccc}
$\left({ }^{\circ} \mathrm{C}\right)$ & & Na-montmorillonite & Ca-montmorillonite & Li-montmor \\
\cline { 1 - 1 } & 95 & 93 & 56 \\
200 & -- & -- & 20 \\
300 & 90 & 41 & - \\
390 & 68 & 12 & -
\end{tabular}

TABLE 4.6. Thermal Stabilities of Selected Montmorillonites on Laboratory Time Scales. [Temperatures given represent the upper boundary for decomposition at 1 to 2 kilobars water pressure (Velde 1977)]

Type of Montmorillonite

K-Al (dioctahedral)

$\mathrm{Na}-\mathrm{Al}$ (dioctahedral)

Ca-Al (dioctahedral)

Mg-Mg (dioctahedral)

K-Al (dioctahedral

layer with illite)
Temperature $\left({ }^{\circ} \mathrm{C}\right)$ 230

350-450

$300-500$

250

400 
From data given by (Grim 1968), montmorillonite undergoes apppreciable dissolution above pH 10 at room temperature. From calculations based on thermodynamic data (Helgeson 1969) at $250^{\circ} \mathrm{C}$, Na-montmorillonite stability relative to kaolinite (low pH) and albite (high pH) is best achieved, for typical cation concentrations in the millimolar range, by maintaining the $\mathrm{pH}$ within the range 5 to 8 . The reader is referred to Section 3.2.9 for a discussion of the factors affecting clay stabililties. 


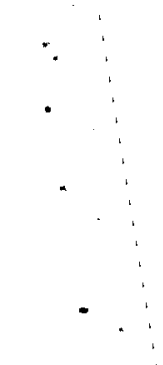




\subsection{LABORATORY TESTING IN PROGRESS}

This section reports progress made to date in the laboratory evaluation of backfill materials. The laboratory testing procedures used were devised to measure backfill performance properties that support and quantify the attributes described in Section 3.2. The initial work has been focused on attributes given the highest priority. Attributes not supported by work reported in this section will be included in work planned for subsequent fiscal years.

\subsection{GROUND-WATER MIGRATION}

As discussed in Section 3.2.1, the ability to slow or stop the migration of water between the host geology and the waste canister system is regarded as a primary attribute of an effective backfill material. The initial experimental work of the project is therefore being directed toward measuring the permeability of candidate materials. Permeabilities or, more specifically, nydraulic conductivities, will be determined as functions of the composition and density of the backfill, temperature, composition of the permeating fluid, and the radiation and thermal history of the candidate backfill materials. Initial experiments to measure hydraulic conductivities of bentonite clay/sand mixtures have been completed. The equipment used in these experiments was designed and constructed to provide information on three backfill attributes-nydraulic conductivity, radionuclide retardation, and swelling pressure.

The first experiments have measured hydraulic conductivities of clay/sand mixtures pressed at $138 \mathrm{MPa}$ to give densities of 2.0 to $2.2 \mathrm{gm} / \mathrm{cm}^{3}$. Synthetic Grande Ronde ground water, similar to natural ground waters that occur at depth beneath the Pasco basin of southcentral Washington, was used as the permeating fluid. Table 5.1 lists the results of these tests. As the clay to sand ratio increases, the hydraulic conductivity decreases; pure sodium bentonite has a conductivity of less than $10^{-12} \mathrm{~cm} / \mathrm{sec}$. As Figure 5.1 shows, the hydraulic conductivity of the $25 \%$ clay $/ 75 \%$ sand mixture dropped rapidly with time before stabilizing at $7 \times 10^{-10} \mathrm{~cm} / \mathrm{sec}$. In order to complete experiments within reasonable time periods, these tests are conducted at larger hydraulic gradients than would be expected in an actual repository. Table 5.1 also shows 
TABLE 5.1. Permeability Tests Summary

\begin{tabular}{|c|c|c|c|c|c|}
\hline Backfill Material & $\begin{array}{r}\text { Density } \\
\left(\mathrm{gm} / \mathrm{cm}^{3}\right) \\
\end{array}$ & $\begin{array}{l}\text { Hydraul ic } \\
\text { Head } \\
\text { (MPa) } \\
\end{array}$ & $\begin{array}{l}\text { Hydraulic } \\
\text { Gradient }\end{array}$ & $\begin{array}{l}\text { Time } \\
\text { (hours) } \\
\end{array}$ & $\begin{array}{l}\text { Hydraulic } \\
\text { Conduct ivity } \\
\text { (cm/sec) } \\
\end{array}$ \\
\hline \multirow[t]{4}{*}{ Na Bentonite } & 2.05 & 15.5 & $1.56 \times 10^{5}$ & 269 & -- \\
\hline & & 6.9 & $6.95 \times 10^{4}$ & 46 & --- \\
\hline & & 20.7 & $2.09 \times 10^{5}$ & 316 & $6.7 \times 10^{-13}$ \\
\hline & 2.13 & 14.6 & $1.56 \times 10^{5}$ & 766 & $5.6 \times 10^{-13}$ \\
\hline \multirow[t]{2}{*}{ Ca Bentonite } & 2.09 & 20.7 & $2.13 \times 10^{5}$ & 858 & $1.3 \times 10^{-12}$ \\
\hline & 2.11 & 15.4 & $1.59 \times 10^{5}$ & 617 & $1.6 \times 10^{-12}$ \\
\hline \multirow{4}{*}{$\begin{array}{l}50 \% \text { Na Bentonite } \\
50 \% \text { Sand ( } 80-120 \text { mesh) }\end{array}$} & 2.12 & 15.5 & $1.62 \times 10^{5}$ & 192 & $4.6 \times 10^{-12}$ \\
\hline & & 6.9 & $7.18 \times 10^{4}$ & 46 & $3.3 \times 10^{-12}$ \\
\hline & & 20.7 & $2.15 \times 10^{5}$ & 1011 & $4.0 \times 10^{-12}$ \\
\hline & 2.09 & 16.7 & $1.73 \times 10^{5}$ & 618 & $6.4 \times 10^{-12}$ \\
\hline $\begin{array}{l}25 \% \text { Na Bentonite } \\
75 \% \text { Sand ( } 80-120 \text { mesh) }\end{array}$ & 2.10 & 3.4 & $1.19 \times 10^{4}$ & 1222 & $6.6 \times 10^{-10}$ \\
\hline \multirow{6}{*}{$\begin{array}{l}50 \% \text { Volclay saline seal } \\
50 \% \text { Sand ( } 80-120 \text { mesh) }\end{array}$} & 2.22 & 15.2 & $1.66 \times 10^{5}$ & 169 & $4.1 \times 10^{-12}$ \\
\hline & & 6.9 & $7.55 \times 10^{4}$ & 72 & --- \\
\hline & & 3.4 & $3.78 \times 10^{4}$ & 62 & $3.5 \times 10^{-12}$ \\
\hline & & 6.9 & $7.55 \times 10^{4}$ & 72 & $3.1 \times 10^{-12}$ \\
\hline & & 20.7 & $2.27 \times 10^{5}$ & 97 & $3.1 \times 10^{-12}$ \\
\hline & & 15.5 & $1.70 \times 10^{5}$ & 334 & $2.9 \times 10^{-12}$ \\
\hline
\end{tabular}




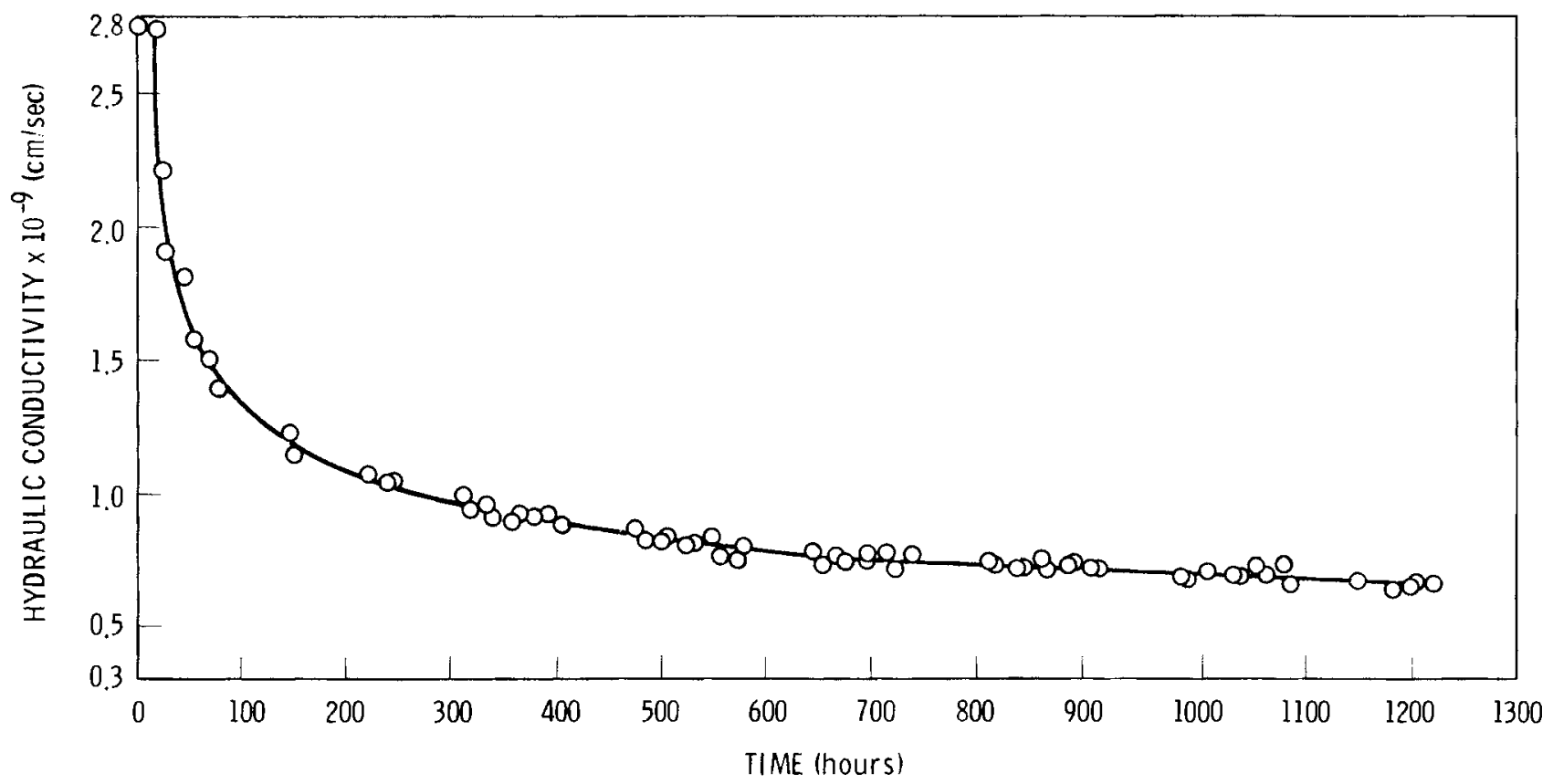

FIGURE 5.1. Hydraulic Conductivity of $25 \%$ Sodium Bentonite Clay/75\% Sand. Initial measured density was $2.1 \mathrm{gm} / \mathrm{cm}^{3}$

that for the $50 \%$ Volclay/50\% sand mixture, the hydraulic conductivities are constant for hydraulic heads of between 3.4 and and $21 \mathrm{MPa}$. At least in this range Darcy's law applies, and it is expected to apply except at very low hydraulic heads.

Figure 5.2 shows a schematic of the test equipment being used to measure hydraulic conductivities. Radionuclide migration and swelling pressure can also be determined with this equipment. The permeating fluid, which may also include radio-tracers, is pumped from the reservoir to the permeability cell. A dual-head, high-pressure liquid chromatography pump is used to ensure pulsefree flow at the high hydraulic heads required. The actual pressure in the system is controlled by the back pressure relief valve and is monitored by the pressure transducer. The hydraulic head is then the gauge pressure, since the effluent end of the permeability cell is open to the atmosphere. The volumetric flow rate is then determined by measuring the volume of solution in the collector as a function of time. 


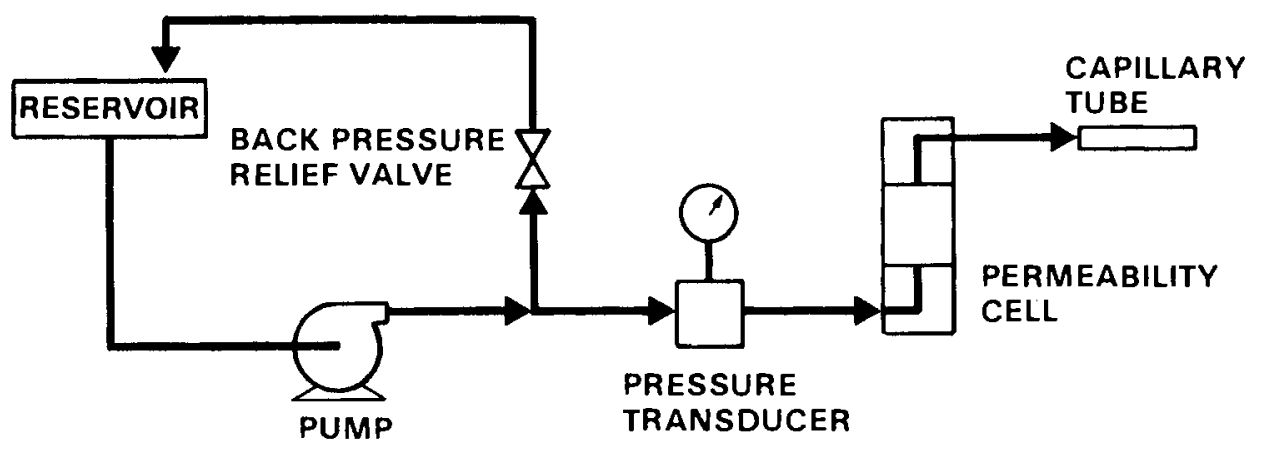

FIGURE 5.2. Schematic of Water/Radionuclide Migration System

Figure 5.3 shows a schematic of the permeability cell itself. Solution flows from the pressure transducer through the lower movable piston to the porous metal disk which disperses the solution over the surface of the test sample. The porous metal disk has a filter rating of 0.5 micron and is used to retain the clay particles that otherwise would be washed away with the permeating fluid. After passing through the sample, the solution passes through a second porous metal disc and is recollected and flows out the top fixed piston to the solution collector. The sample diameter is constant at $5.0 \mathrm{~cm}$ and samples tested to date have been approximately $1 \mathrm{~cm}$ thick. The sample is actually pressed in place using a separate set of dies and an air hydraulic press. A load cell has been added to the permeability cell to monitor the swelling pressures of candidate backfill materials as they saturate with the permeating fluid.

Four systems have been fabricated from stainless steel. Two additional systems have Inconel and Hastelloy parts for tests using permeating fluids with high-chloride contents. 


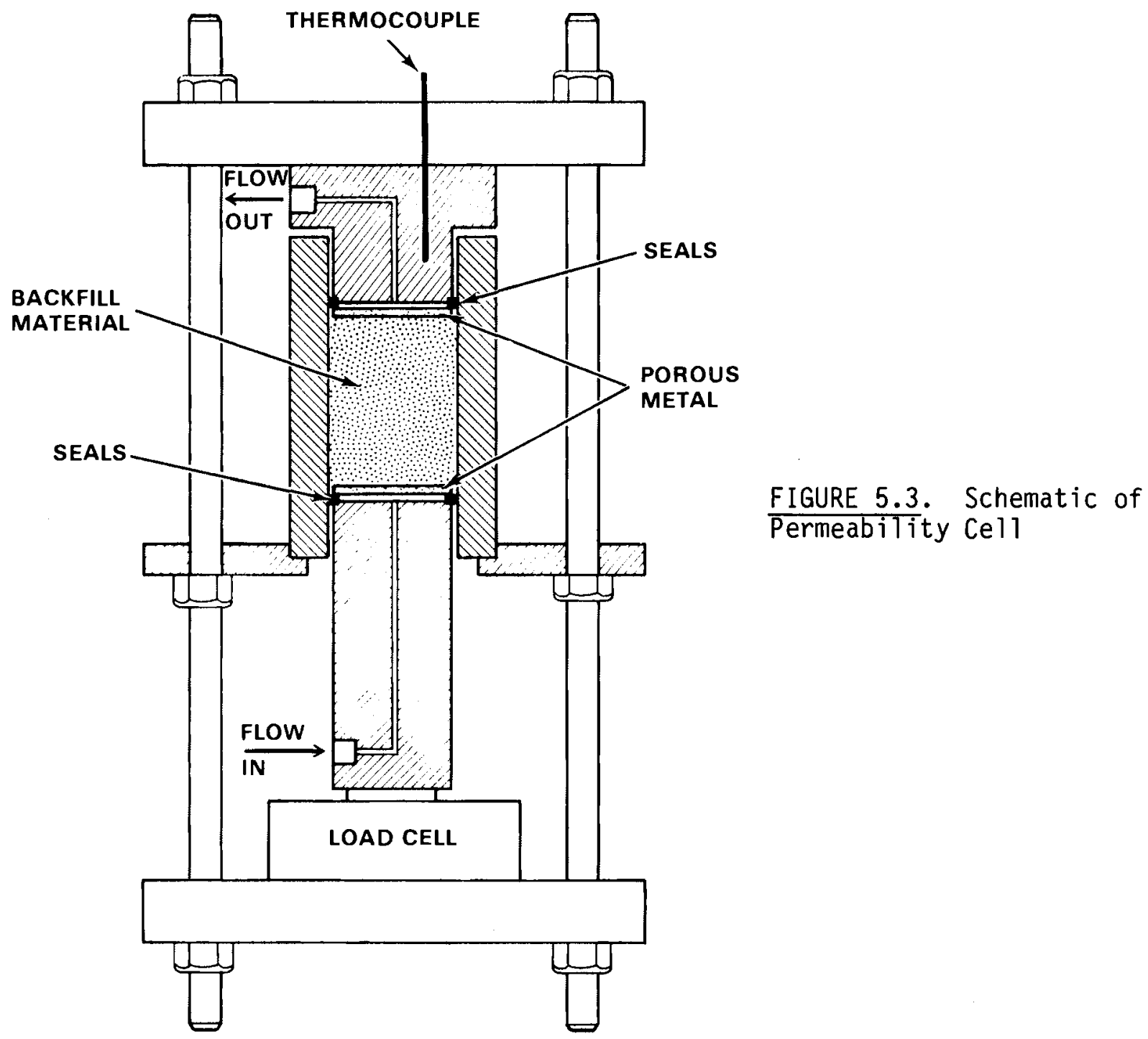

\subsection{RETARDATION OF SELECTED CHEMICAL SPECIES}

Retardation is ranked as the second most important attribute of a backfill. In this role the backfill will reduce the rate of migration of selected chemical species dissolved in the ground water to values that are significantly less than the rate of migration of the ground water. Primary interest is directed at the migration of radionuclides leached from the waste after the canister-overpack barrier system ceases to function as a barrier. In addition, the removal or delay of corrosion agents from the ground water before the ground water can reach the canister-overpack system by selected materials incorporated into the backfill is being investigated. The measurement of the 
retardation attribute in relation to others, methods used for its measurements, and initial laboratory results are discussed in this section.

Retardation factors are being determined for those radionuclides that have been identified to pose the greatest potential hazard to man during long-term storage of nuclear waste. Radionuclides under investigation are shown below.

$$
\begin{aligned}
& \text { Technetium, }{ }^{99} \mathrm{Tc} \\
& \text { Iodine, }{ }^{129}{ }^{\mathrm{I}} \\
& \text { Neptunium, }{ }^{237} \mathrm{~Np} \\
& \text { Uranium, }{ }^{233} \mathrm{U} \\
& \text { Plutonium, }{ }^{239} \mathrm{Pu} \\
& \text { Strontium, }{ }^{90} \mathrm{Sr} \\
& \text { Cesium, }{ }^{137} \mathrm{Cs} \\
& \text { Americium, }{ }^{241} \mathrm{Am}
\end{aligned}
$$

Additional radionuclides will be added to the test program as they are identified or if time permits at the end of the primary investigation.

\subsubsection{Batch Sorption Measurements}

Batch experiments provide an excellent method to screen a wide variety of potential backfill materials under similar conditions. While such tests give relative retardation factors $(\mathrm{Kd}, \mathrm{ml} / \mathrm{gm})$, the results are difficult to relate to flow experiments. Batch experiments involve contacting a sample of ground water containing the radionuclide under investigation with a small weighed sample of backfill material. After contact the sample of ground water is filtered and analyzed. Temperature, pH, contact time, and water chemistry contribute to the effectiveness of the material being tested.

\subsubsection{Ground-Water Preparation}

The accepted standard compositions for synthetic Grande Ronde (Columbia River basalt), Granite and Tuff ground waters and the WIPP salt Brine B are shown in Table 5.2. Synthetic stock solutions of Grande Ronde ground water and WIPP Brine B have been prepared. Granite and Tuff ground waters have not been prepared. 
TABLE 5.2. Composition of Ground Waters Under Investigation

\begin{tabular}{|c|c|c|c|c|}
\hline \multirow[b]{2}{*}{ Chemical Species } & \multicolumn{4}{|c|}{ Ground-Water Compositions } \\
\hline & $\begin{array}{c}\text { Grande Ronde } \\
(\mathrm{mg} / \mathrm{l}) \\
\end{array}$ & $\begin{array}{l}\text { Brine } B \\
(\mathrm{mg} / \mathrm{l})\end{array}$ & $\begin{array}{l}\text { Tuff } \\
(\mathrm{mg} / \mathrm{l}) \\
\end{array}$ & $\begin{array}{l}\text { Granite } \\
(\mathrm{mg} / \mathrm{l})\end{array}$ \\
\hline $\mathrm{Na}^{+}$ & 263 & $\overline{115,00}$ & 51 & 7.5 \\
\hline $\mathrm{K}^{+}$ & 1.9 & 15 & 4.9 & 4.8 \\
\hline $\mathrm{Ca}^{2+}$ & 1.3 & 900 & 14 & 9.6 \\
\hline $\mathrm{Mg}^{2+}$ & 0.04 & 10 & 2.1 & 2.0 \\
\hline $\mathrm{Ba}^{2+}$ & - & -- & 0.003 & 0.3 \\
\hline$S r^{2+}$ & - & 15 & 0.05 & 0.07 \\
\hline $\mathrm{Fe}^{3+}$ & -- & 2 & 0.04 & 0.4 \\
\hline Si & 60 & -- & 61 & 7.9 \\
\hline $\mathrm{Li}^{+}$ & -- & -- & 0.03 & 0.03 \\
\hline $\mathrm{Rb}^{+}$ & - & 1 & -- & - \\
\hline $\mathrm{Cs}^{+}$ & -- & 1 & -- & - \\
\hline $\mathrm{CO}_{3}{ }^{2-}$ & 27 & -- & 0 & 0 \\
\hline $\mathrm{HCO}_{3}^{-}$ & 70 & 10 & 120 & 5 \\
\hline $\mathrm{OH}^{-}$ & 1.4 & -- & -- & -- \\
\hline $\mathrm{Cl}^{-}$ & 148 & 175,000 & 7.5 & 2.3 \\
\hline $\mathrm{SO}_{4}^{2-}$ & 109 & 3,500 & 22 & 5.1 \\
\hline $\mathrm{F}^{-}$ & 37 & -- & 2.2 & 0.3 \\
\hline $\mathrm{Br}^{-}$ & -- & 400 & -- & -- \\
\hline $\mathrm{I}^{-}$ & -- & 10 & - & -- \\
\hline $\mathrm{BO}_{3}^{3-}$ & - & 10 & -- & -- \\
\hline $\mathrm{NO}_{3}^{-}$ & -- & -- & 5.6 & -- \\
\hline $\mathrm{pH}$ & 9.9 & 6.5 & 8.5 & -- \\
\hline $\mathrm{PO}_{4}^{3-}$ & - & -- & 0.12 & - \\
\hline
\end{tabular}


Special precautions are taken when adding radiotracers to synthetic ground water to ensure that the tracer is in solution and not precipitated. A known aliquot of radiotracer is added to $20 \mathrm{ml}$ of the reagent ground water and stirred for 7 days to allow equilibration. The solution is then filtered and added to the starting volume of ground water required for a series of batch or flow experiments.

\subsubsection{Candidate Backfill Material Preparation}

A sample of material $(0.1$ to $0.5 \mathrm{gm})$ is weighed out on a 4 - or 5-place balance for each test. If the sample contains $\mathrm{H}_{2} \mathrm{O}$, the sample is dried at $105^{\circ} \mathrm{C}$ for 24 hours before weighing. One or two samples are weighed for each test and placed in a $25 \mathrm{ml}$ polyethylene bottle. Three methods can then be used to add the ground water. Ten milliliters of radionuclide-free ground water $c$ an be added to the material and placed on a mechanical shaker for 24 hours. The pH of each solution is then recorded, the ground water removed, and a second and third $10 \mathrm{ml}$ aliquot added until the pH stabilizes near the original $\mathrm{pH}$ value. A second method is to adjust the $\mathrm{pH}$ of the solution using $\mathrm{NaOH}$ or HCL. A third method is to do nothing. On completion of one of the above steps, a second "spiked" aliquot $(10 \mathrm{ml})$ is added to the original volume. The bottle is tightly capped and placed on a mechanical shaker for continuous . agitation.

\subsubsection{Blanks and Acid Standards}

A set of two blanks and two acid standards are prepared for each radionuclide. Each "blank" standard contains $10 \mathrm{ml}$ of "spiked" ground water and $10 \mathrm{ml}$ of "cold" ground water. Each "acid" standard contains $10 \mathrm{ml}$ of "spiked" ground water and $10 \mathrm{ml}$ of $0.2 \mathrm{M} \mathrm{HCl}$. Each standard is tightly capped and placed on a mechanical shaker and treated as a normal sample.

\subsubsection{Filtering and Analysis Procedure}

The samples and standards are removed from the shaker (one to two weeks) and allowed to settle for 24 hours. Approximately $3 \mathrm{ml}$ of each sample and standard are placed in "Centriflo Membrane Cones", type CF 25, having 95\% retention for molecules above $25,000 \mathrm{MW}(16 \AA)$. The cone is placed in polyethylene supports and polycarbonate tubes. The tubes are centrifuged in an 
International Equipment Co., Model HN, centrifuge for 10 to 30 minutes at 1700 PRM. After centrifugation, $2 \mathrm{ml}$ of solution is transferred to standard counting tubes. Each sample is counted for 2 to 10 minutes in the appropriate radioanalytical counting equipment. The final pH of each blank, acid standard, and sample is measured.

\subsubsection{Reporting Method}

$$
K_{d}=\frac{\text { Standard }- \text { Sample }}{\text { Sample }} \times \frac{\text { Sample Volume }}{\text { Weight of Materia }}=\mathrm{ml} / \mathrm{gm}
$$

Standard = 1) Filtered "Blank" radionuclide concentration

2) Filtered "Acid" radionuclide concentration

The retardation factor $\left(K_{d}\right)$ is determined for the "blank" and the "acid" standard. The same $K_{d}$ value for each standard indicates that the radiotracer behaved identically, did not precipate or sorb on the walls of the plastic bottle, and filtered with equal recovery.

\subsubsection{Laboratory Results}

Batch distribution $\left(K_{d}\right)$ values are being determined using commerciallyavailable materials for backfill evaluation. Samples of each were contacted with synthetic Grande Ronde ground water containing radiotracers. The results are shown in Table 5.3. The samples were equilibrated for 14 and 28 days prior to sampling. The results show that strontium and cesium are retained by the clays and zeolites. Iodine was retained by the pyrite but the lowered $\mathrm{pH}$ of the resulting solution indicates that pyrite may not be a desirable backfill component .

\subsubsection{Flow-Cell Sorption Measurements}

Flow-through experiments are being conducted using the water migration equipment shown in Figures 5.2 and 5.3. In addition to the determination of hydraulic conductivity and swelling pressures of selected bentonite clays and clay/sand mixtures, the ground-water effluents are being analyzed for the major cations, anions and pH. Selected radionuclides will then be added to the ground waters to observe their behavior and to relate these values with relative retardation factors $\left(K_{d}\right)$ previously determined by batch contact. After 
TABLE 5.3. Batch Distribution $\left(K_{d}\right)$ Values for Backfill Candidates Ground Water: Grande Ronde, pH 9.85 (initial), $\mathrm{pH} 8.6$ (final standard)

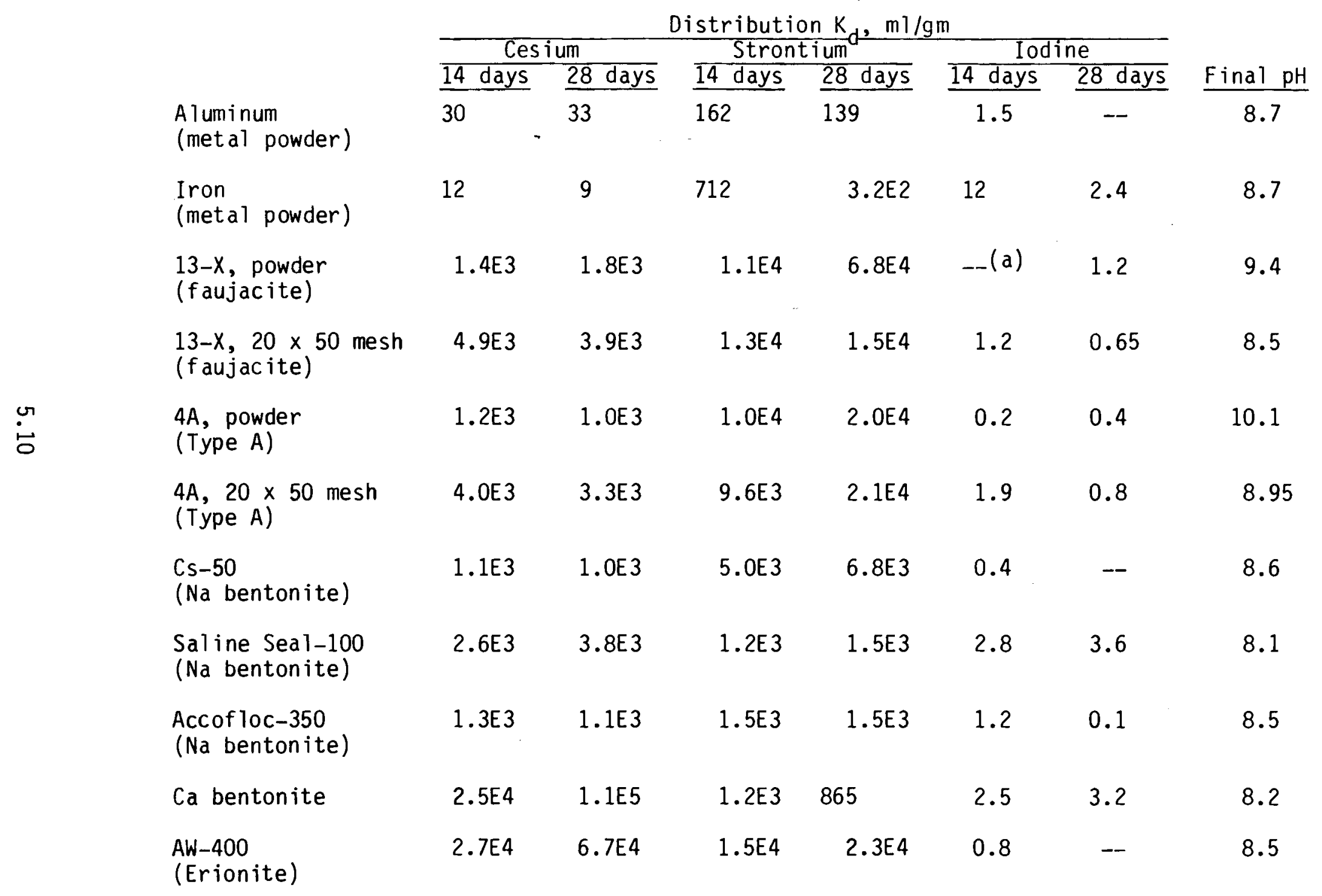


TABLE 5.3. (contd)

\begin{tabular}{|c|c|c|c|c|c|c|c|}
\hline & \multicolumn{6}{|c|}{ Distribution $\mathrm{K}, \mathrm{ml} / \mathrm{gm}$} & \multirow[b]{3}{*}{ Final $\mathrm{pH}$} \\
\hline & \multicolumn{2}{|c|}{ Cesium } & \multicolumn{2}{|c|}{ Strontium } & \multicolumn{2}{|c|}{ Iodine } & \\
\hline & 14 days & 28 days & 14 days & 28 days & 14 days & 28 days & \\
\hline $\begin{array}{l}\text { AW-500 } \\
\text { (chabazite) }\end{array}$ & $4.8 \mathrm{E} 4$ & $7.8 \mathrm{E} 4$ & $2.8 \mathrm{E} 3$ & $2.3 \mathrm{E} 3$ & 1.8 & 1.5 & 8.4 \\
\hline $\begin{array}{l}\text { Zeolon-900 } \\
\text { (mordenite) }\end{array}$ & 4.7E4 & $8.3 E 4$ & $2.0 \mathrm{E} 4$ & $1.5 \mathrm{E} 4$ & 3.5 & 1.8 & 8.6 \\
\hline $\begin{array}{l}\text { Ferrosand } \\
\text { (glauconite) }\end{array}$ & $6.0 \mathrm{E} 3$ & $5.2 \mathrm{E} 3$ & $3.8 \mathrm{E} 3$ & $4.1 \mathrm{E} 3$ & 2.5 & 1.1 & 7.9 \\
\hline Pyrite, $\mathrm{FeS}_{2}$ & 6 & 4 & 99 & 140 & $2.9 \mathrm{E} 3$ & $5.1 \mathrm{E} 3$ & 2.8 \\
\hline $\begin{array}{l}\text { Mixture: } \\
10 \text { wt\% iron } \\
10 \text { wt\% aluminum } \\
13 \text { wt\% FeS } \\
50 \text { wt\% CS-50 } \\
17 \text { wt\% } 13 x \text {, powder }\end{array}$ & 785 & 800 & $1.1 \mathrm{E} 4$ & $1.2 \mathrm{E} 3$ & 2.6 & 10 & 8.5 \\
\hline
\end{tabular}

(a) -- = count rate greater than standard value. 
completion of the flow-through experiments, the test sample will be extruded from the test chamber and sections of the core can be analyzed using conventional radioanalysis techniques to determine depth of radionuclide penetration through the backfill material.

\subsubsection{Ground-Water Preparation}

Standard synthetic solutions of ground water are prepared as shown in Section 5.2.1.1.

\subsubsection{Flowcell}

The radionuclide containing solution is placed in an auxiliary reservoir, separated from the main flow by a valve. When the backfill material is saturated with ground water, the valve is switched allowing the radiotraced solution to flow through the pump system and out a small sampling port, just prior to entry into the permeability cell. When analysis of the fluid at the sample port indicates that the line has been flushed the valve is turned off and the radiotraced ground water then flows directly to the flowcell.

\subsubsection{Sampling}

Samples of the influent and effluent are being taken to determine progress of the radioactive ion through the backfill material and to show changes in ground-water composition as cations and anions are sorbed and/or released during flow through the clay/sand compacts.

\subsubsection{Laboratory Results}

Synthetic Grande Ronde ground water, typical of a ground water from a basalt geological formation, shows a significant change in composition as cations and anions are sorbed and/or released during flow through the clay/sand compacts. The effluent water samples were obtained by passing ground water through a 1:3 Na-bentonite/sand mixture, a 1:1 Na-bentonite/sand mixture, and a calciumbentonite compact. In each case, the 42-gm sample was compacted to a density of $2.1 \mathrm{gm} / \mathrm{cm}^{3}$, in the form of a 5-cm dia by approximately 1-cm-thick cylinder. The results are shown in Tables 5.4, 5.5 and 5.6. 
TABLE 5.4. Analysis of Grande Ronde Ground-Water Effluent After Flowing Through Compacted 25 wt\% Sodium bentonite (CS-50)/Sand: $\sim 1 \mathrm{~cm}$ thick, $42 \mathrm{gm}, 2.16 \mathrm{gm} / \mathrm{cm}^{3}$

\begin{tabular}{|c|c|c|c|c|c|c|c|c|c|}
\hline \multicolumn{2}{|c|}{ Sample No. } & Feed & $1-3-9$ & $1-3-10$ & $1-3-30$ & $1-3-40$ & $1-3-49$ & $1-3-59$ & $1-3-68$ \\
\hline \multicolumn{2}{|c|}{ Elapsed Time (hrs) } & - & 77 & 142 & 478 & 646 & 814 & 982 & 1150 \\
\hline \multicolumn{2}{|c|}{ Effluent $\mathrm{pH}$} & 9.9 & 9.1 & 9.86 & 9.51 & 9.55 & 9.07 & 9.00 & 9.56 \\
\hline \multicolumn{2}{|c|}{ Effluent $\mathrm{H}_{2} \mathrm{O}(\mathrm{g})$} & & 137 & 207 & 487 & 603 & 712 & 816 & 916 \\
\hline \multicolumn{3}{|c|}{ Pump pressure (MPa) } & 3.45 & 3.45 & 3.45 & 3.45 & 3.45 & 3.45 & 3.45 \\
\hline \multicolumn{2}{|c|}{ Assigned Value (mg/L) } & \multicolumn{8}{|c|}{ Analys is $(\mathrm{mg} / \mathrm{L})$} \\
\hline $\mathrm{Ca}$ & 1.3 & 0.7 & 0.93 & 0.72 & 0.62 & 0.64 & 0.43 & 0.47 & 0.47 \\
\hline K & 1.9 & 2.1 & 2.9 & 2.8 & 2.7 & 2.5 & 2.4 & 2.6 & 2.5 \\
\hline $\mathrm{Mg}$ & 0.04 & 0.2 & 0.26 & 0.19 & 0.16 & 0.14 & 0.08 & 0.10 & 0.10 \\
\hline $\mathrm{Si}$ & 60 & 60 & 14.2 & 14.2 & 18 & 20.2 & 21.8 & 24.6 & 26.7 \\
\hline $\mathrm{Sr}$ & - & - & 0.02 & 0.02 & 0.02 & 0.02 & 0.014 & 0.013 & 0.014 \\
\hline $\mathrm{Na}$ & 250 & 288 & 324 & 311 & 280 & 292 & 273 & 288 & 286 \\
\hline $\mathrm{Cl}^{-}$ & 148 & 156 & - & - & 146 & 146 & 145 & 144 & 149 \\
\hline $\mathrm{SO}_{4}^{2-}$ & 108 & 92 & - & - & 129 & 121 & 126 & 119 & 121 \\
\hline $\mathrm{F}^{-}$ & 37 & 40 & - & - & 35.5 & 30 & 35.7 & 35.5 & 36.8 \\
\hline
\end{tabular}


TABLE 5.5. Analys is of Grande Ronde Ground-Water Effluent After Passing Through Compacted 50 wt\% Sodium Bentonite (CS-50)/50 wt\% Sand: $\sim 1 \mathrm{~cm}$ thick, $42 \mathrm{gm}, 2.1 \mathrm{gm} / \mathrm{cm}^{3}$

$\begin{array}{llllll}\text { Sample No. } & \text { Feed } & 3-2-24 & 6-1-15 & 3-2-33 & 3-2-41 \\ \text { Elapsed time (hrs) } & -- & 414 & 568 & 675 & 1180 \\ \text { Effluent } \mathrm{pH} & 9.9 & 8.30 & 9.20 & 8.05 & 8.18 \\ \text { Effluent } \mathrm{H}_{2} \mathrm{O}(\mathrm{g}) & & 30.6 & 47.5 & 49.2 & 69.6\end{array}$

\begin{tabular}{lcccccc}
\multicolumn{2}{l}{ Assigned Value } & $(\mathrm{mg} / \mathrm{L})$ & \multicolumn{2}{l}{ Analysis $(\mathrm{mg} / \mathrm{L})$} \\
\cline { 4 - 7 } $\mathrm{Ca}$ & 1.3 & 0.7 & 1.35 & 1.2 & 0.34 \\
$\mathrm{~K}$ & 1.9 & 2.1 & 0.66 & 0.9 & 0.53 \\
$\mathrm{Mg}$ & 0.04 & 0.2 & 0.25 & 0.33 & 0.12 \\
$\mathrm{Si}$ & 60 & 60 & 4.3 & & 3.9 & 3.5 \\
$\mathrm{Sr}$ & - & - & 0.03 & & 0.03 & 0.01 \\
$\mathrm{Na}$ & 250 & 288 & 241 & & 225 & 195 \\
$\mathrm{Cl}^{-}$ & 148 & 156 & - & 145 & 130 & 87 \\
$\mathrm{SO}_{4}^{2-}$ & 108 & 92 & - & 143 & 152 & 133 \\
$\mathrm{~F}^{-}$ & 37 & 40 & - & 12.8 & 19.1 & 15.7
\end{tabular}

The effluent ground-water samples show that for:

- 1:3 Na-Bentonite/Sand

Fifty percent of the ground-water silica $(60 \mathrm{mg} / \mathrm{L})$ is retained by the compact after 54 bed volumes had passed through the cell at 15 to $20 \mathrm{MPa}$, in 1320 hours.

- 1:1 Na-Bentonite/Sand

Sixty-eight percent of the fluoride ion $(40 \mathrm{mg} / \mathrm{L})$ and silica are retained by the compact after 3.5 bed volumes.

- Ca-Bentonite

Eight-eight percent of the silica, $100 \%$ of the potassium $(2.1 \mathrm{mg} / \mathrm{L})$, and $96 \%$ of the sodium $(288 \mathrm{mg} / \mathrm{L})$ is retained by the compact after 1 bed volume, releasing $108 \mathrm{mg} \mathrm{calcium} / \mathrm{L}$ and $321 \mathrm{mg}$ of sulfate/L. The original ground water contained $92 \mathrm{mg}$ of sulfate and $0.72 \mathrm{mg}$ of calcium/L. 
TABLE 5.6. Analys is of Grande Ronde Ground-Water Effluent After Flowing Through Compacted 100 wt\% Calcjum Bentonite (Panther Creed): $\sim 1 \mathrm{~cm}$ thick, $42 \mathrm{gm}, 2.09 \mathrm{gm} / \mathrm{cm}^{3}$

$\begin{array}{lllllll}\text { Sample No. } & \text { Feed } & 5-1-2 & 5-1-8 & 2-2-6 & 2-2-8 & 2-2-9 \\ \text { Elapsed time (hrs) } & -- & 305 & 544 & 451 & 722 & 855 \\ \text { Effluent pH } & 9.9 & 7.75 & 8.10 & 8.33 & 8.33 & 8.30 \\ \text { Effluent } \mathrm{H}_{2} \mathrm{O}(\mathrm{g}) & & 2.35 & 6.7 & 6.93 & 10.32 & 14.65 \\ \text { Pump pressure (MPa) } & & 15.16 & 15.16 & 20.67 & 20.67 & 20.67\end{array}$

Assigned Value (mg/L) Analysis (mg/L)

\begin{tabular}{|c|c|c|c|c|c|c|c|}
\hline $\mathrm{Ca}$ & $1.3 \mathrm{mg} / \mathrm{L}$ & 0.7 & & & 145 & 115 & 108 \\
\hline K & 1.9 & 2.1 & & & ND & ND & ND \\
\hline $\mathrm{Mg}$ & 0.04 & 0.2 & & & 18.9 & 15.1 & 14.5 \\
\hline $\mathrm{Si}$ & 60 & 60 & & & 7 & 7 & 6.9 \\
\hline $\mathrm{Sr}$ & - & - & & & 11.8 & 9.5 & 4.9 \\
\hline $\mathrm{Na}$ & 250 & 188 & & & 5.7 & 8.2 & 10.9 \\
\hline $\mathrm{Cl}^{-}$ & 148 & 156 & 91.8 & 61.6 & - & - & - \\
\hline $\mathrm{SO}_{4}^{2-}$ & 108 & 92 & 479 & 321 & - & - & - \\
\hline $\mathrm{F}^{-}$ & 37 & 40 & 7.5 & 7.0 & - & - & - \\
\hline $\mathrm{NO}_{3}^{-}$ & - & - & 6.7 & $<2$ & - & - & - \\
\hline
\end{tabular}

\subsection{COMPACTION OF BACKFILL CANDIDATES}

Zeolites ( $10 \AA$ and 20 to 40 mesh), quartz sand ( 80 to 120 mesh), iron and aluminum metal powders, and several types of clays are being mixed in various ratios and pressed in an air-hydraulic press to obtain densities as a function of pressing conditions. The objective is to obtain a backfill material composition that will maintain its physical shape during placement and will minimize migration of water and radionuclides. Densities of 2 to $2.6 \mathrm{gm} / \mathrm{cm}^{3}$ have been obtained at pressures ranging from $55 \mathrm{MPa}$ to $221 \mathrm{MPa}$.

The compaction density of sodium bentonite (CS-50)\% was determined as a function of compaction pressure ( 55 to $221 \mathrm{MPa}$ ) and water content (0 to 14 wt\% $\mathrm{H}_{2} \mathrm{O}$ ). The results are shown in Figure 5.4. The density of clay compacts increased with increasing compaction pressure at constant water content. At 


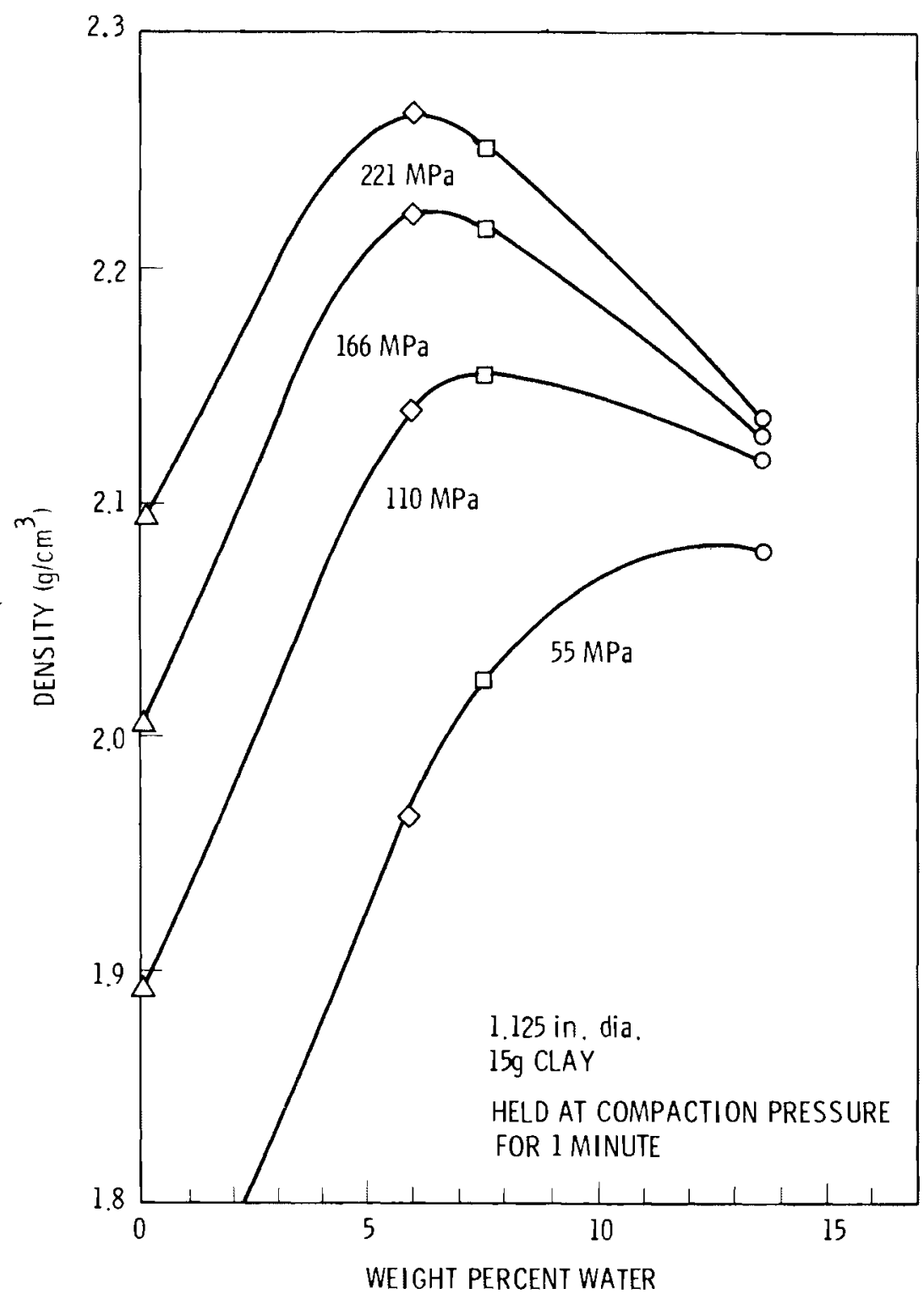

FIGURE 5.4. Density of Sodium Bentonite (Volclay, CS-50) as a Function of Compaction Pressure and $\mathrm{H}_{2} \mathrm{O}$ Content

constant compaction pressures, maximum densities were obtained at 5 to $8 \mathrm{wt} \%$ $\mathrm{H}_{2} \mathrm{O}$. Densities of $2.14,2.23$, and $2.27 \mathrm{gm} / \mathrm{cm}^{3}$ were obtained for $2.86-\mathrm{cm}-$ (1.124-in.-)dia pellets at $5.8 \mathrm{wt} \% \mathrm{H}_{2} \mathrm{O}$ content using compaction pressures of 110,165 , and $221 \mathrm{MPa}$, respectively. Similar results were obtained for Saline Sea $1-100 \%$.

The compaction density of naturally occurring calcium bentonite was determined as a function of compaction pressure ( 55 to $221 \mathrm{MPa}$ ) and water content 


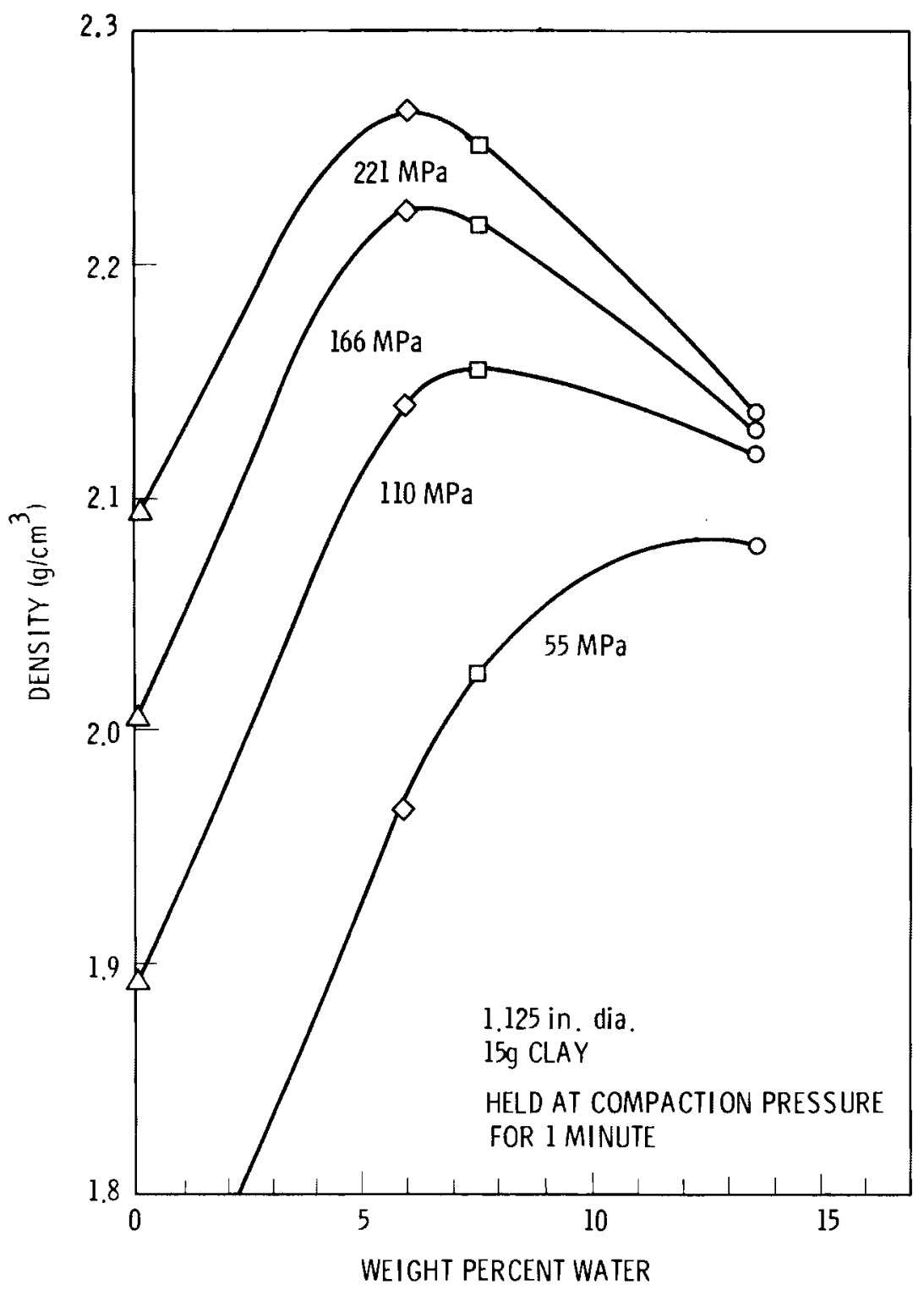

FIGURE 5.5. Density of Panther Creek Calcium Bentonite as a Function of Compaction Pressure and $\mathrm{H}_{2} \mathrm{O}$ Content

(0. to $28 \mathrm{wt} \% \mathrm{H}_{2} \mathrm{O}$ ). A reference point of $0.0 \mathrm{wt} \%$ absorbed water was assumed for clay that was heated at $110^{\circ} \mathrm{C}$ for 16 hours. Vacuum drying at the same temperature for the same time gave comparable dehydration. On this basis, the as-received clay contained $7.5 \mathrm{wt} \%$ absorbed water. Clays of higher hydration were obtained by equilibration with water vapor in a sealed system. After the pressed pellets were weighed and measured, each was dehydrated by heating in 
an oven at $110^{\circ} \mathrm{C}$ for 16 hours. These results are given in Figure 5.5. As compared to previous results for sodium bentonite, CS-50, the compaction densities were lower, but for the higher compaction pressures the results showed similar dependence on water content. Densities of $1.8,2.01,2.10$ and $2.14 \mathrm{gm} / \mathrm{cm}^{3}$ were obtained for 2.86-cm- (1.125-in.-)dia pellets at 8 wt\% $\mathrm{H}_{2} \mathrm{O}$ content using compaction pressures of 55, 110, 166, and $221 \mathrm{MPa}$, respectively.

\subsection{MEASUREMENT OF CLAY SWELLING PRESSURES}

As noted in Section 5.1, the clay swelling pressure generated as the clay sorbs water is measured concurrently with measurements of the hydraulic conductivity. The load cell shown in Figure 5.3 is connected to a continuous recorder and is used to monitor the swelling pressure. An initial reading of the load cell is noted after the nuts of the tie-rods are torqued down and before water is pumped into the system. When water is pumped into the cell, the clay starts to absorb water and to exert an ever increasing pressure on the load cell until equilibrium is reached and the pressure on the load cell reaches a constant value. The hydraulic head is then reduced to zero and the effect upon the load cell readout is noted. Each time the applied hydraulic head is changed from one value to another, the hydraulic head is reduced to zero to subtract the hydraulic head from the load cell reading. The limited number of swelling pressure measurements completed to date are given in Table 5.7 .

\section{TABLE 5.7. Swe11ing Pressures}

\begin{tabular}{|c|c|c|}
\hline Backfill Material & $\begin{array}{l}\text { Initial } \\
\text { Measured } \\
\text { Density } \\
(\mathrm{gm} / \mathrm{cm}) \\
\end{array}$ & $\begin{array}{c}\text { Swelling Pressure } \\
\text { (MPa) }\end{array}$ \\
\hline $\mathrm{Na}$ Bentonite & 2.13 & 57.7 \\
\hline Ca Bentonite & 2.11 & 31.4 \\
\hline $\begin{array}{l}50 \% \text { Na Bentonite } \\
50 \% \text { Sand ( } 80-120 \text { mesh) }\end{array}$ & 2.09 & 21.7 \\
\hline
\end{tabular}




\subsection{REFERENCES}

Ames, L. L., and J. E. McGarrah. 1980. Basalt-Radionuclide Distribution Coefficient Determinations FY-1979 Annual Report. PNL-3146, Pacific Northwest Laboratory, Richland, Washington.

Altwell, P. B., and I. W. Farmer. 1976. Principles of Engineering Geology. Chapman and Hall, London, pp. 1045.

Baas Becking, L. G. N., I. R. Kaplan, and D. Moore. 1960. "Limits of the Natural Environment in Terms of $\mathrm{pH}$ and Oxidation-Reduction Potentials." J. Geol. 68:243-284.

Bolt, G. H., and P. H. Groenevelt. 1969. "Coupling Phenomena as a Possible Cause for Non-Darcian Behavior of Water in Soil." Bull. Intern. Assoc. Sci. Hydrol. 14(2):17-26.

Barney, G. S. and B. J. Wood. 1977. Identification of Key Radionuclides in a Nuclear Waste Repository in Basalt. Rockwell Hanford Operations, RHO-WI-ST-9.

Corbett, W. J., J. H. Burson and R. A. Young. 1963. "Gamma-Irradiation of Kaolinite." Proc. of the Tenth National Conference on Clays and Clay Minerals, Pergamon Press, p. 344-355.

Department of Energy. 1979. Technology for Commercial Radioactive Waste Management. DOE/ET-0028.

Electric Power Research Institute. 1979. Nuclear Waste Management Status and Recent Accomplishments, Final Report. EPRI NP-1087, P. 5-1.

Ewing, R. C. and R. F. Haaker. 1979. Naturally Occurring Glasses; Analogues for Radioactive Waste Forms. PNL-2776, Pacific Northwest Laboratory, Richland, Washington.

Freeze, R. A., and J. A. Cherry. 1979. Ground Water. Prentice-Hall, pp 604.

Fried, S. and A. Friedman. 1979. "Kinetic Effects in Migration," Radioactive Waste in Geologic Storeage. ACS Symposium Series 100.

Garrels, R. M., and C. L. Christ. 1965. Solutions, Minerals, and Equilibria. Freeman, Cooper, and Company, San Francisco, $450 \mathrm{p}$.

Gera, F. 1972. "Review of Salt Tectonics in Relation to the Disposal of Radioactive Wastes in Salt Formations." Geo. Soc. of Am. Bull. V. 83.

Gillott, J. E. 1968. Clay in Engineering Geology. Elsevier Pub. Co., pp. 296. 
Helgeson, H. C., T. H. Brown and R. H. Leeper. 1969. Handbook of Theoretical Activity Diagrams Depicting Chemical Equilibrium in Geologic Systems Involving an Aqueous Phase at One Atm and $0^{\circ}$ to $300^{\circ} \mathrm{C}$. Freeman, Cooper, San Francisco, California.

Hubbert, N. K. 1940. "The Theory of Ground-Water Motion. J. Geol. $48: 785-944$.

Jenks, G. H. 1979. Effects of Temperature, Temperature Gradients, Stress, and Irradiation on Migration of Brine Inclusions in a Salt Repository. ORNL-5526, Oak Ridge National Laboratory Oak Ridge, Tennessee.

Kharaka, Y. K., and W. C. Smalley. 1976. "Flow of Water and Solutes Through Compacted Clays." Amer. Assoc. Petrol. Geol. Bull. 60:973-980.

Komarneni, S. and D. M. Roy. 1979. "Shale as a Radioactive Waste Repository: The Importance of Vermiculite." J. Inorg. Nucl. Chem. 41:1793-1796.

Morris, J. C. and W. L. Stumm. 1967. "Redox Equilibria and Measurement of Potentials in the Aquatic Environment in Equilibrium Concepts in Natural Water Systems." Advances in Chemistry Series No.67. American Chemical Society, Washington, D.C.

LeBell, J. C. 1978. Colloid Chemical Aspects of the Confined Bentonite Concept. KBS Report 97, 1978-03-07.

Lester, D. H. et al. 1979. System Study on Engineered Barriers, Task 3-Barrier Performance Analysis Final Report. SAI01379-990LJ.

Lester, D. H., G. Jansen and H. C. Buckholder. 1975. Migration of Radionuclide Chains Through an Adsorbing Medium. AIChE Symposium Series, Vo1. 71, 152:202.

Lindsay, W. L. 1979. Chemical Equilibria in Soils. Wiley-Interscience, New York, New York.

Low, P. F. and J. F. Margheim. 1979. "The Swelling of Clay I." Soil Sci. Soc. Amer. J. 43:473-481.

Low, P. F. 1979. "The Swelling of Clay II. Montmorillonites." Purdue Univ. Agric. Exp. Stn. West Lafayette, Indianna.

Neretnieks, I. 1977. Retardation of Escaping Nuclides from a Final Depository. KBS Report No. 130, Stockholm, Sweden.

Nowak, E. G. 1979. The Backfill as an Engineered Barrier for Nuclear Waste Management. SAND79-0990C, Sandia National Laboratories, Albuquerque, New Mexico. 
Low, P. F. 1976. "Viscosity of Interlayer Water in Montmorillonite." Journal Paper No. 6065, Dept. of Agronomy, Purdue University Agric. Exp. Stn., Lafayette, Indiana.

Low, P. F. 1979. "The Swelling of Clay II. Montmorillonites." Purdue Univ. Agric. Exp. Stn. West Lafayette, Indianna.

Neretnieks, I. 1977. Retardation of Escaping Nuclides from a Final Depository. KBS Report No. 130, Stockholm, Sweden.

Nowak, E. G. 1979. The Backfill as an Engineered Barrier for Nuclear Waste Management. SAND79-0990C, Sandia National Laboratories, Albuquerque, New Mexico.

Nowak, E. G. 1980a. The Backfill Barrier as a Component in a Multibarrier Nuclear Wast Isolation System. SAND79-1109 (draft), Sandia National Laboratories, Albuquerque, New Mexico.

Nowak, E. G. 1980b. Radionuclide Sorption and Migration Studies of Getters for Backfill Barriers. SAND79-1110, Sandia National Laboratories, Albuquerque, New Mexico.

PNL. 1978. Proceedings of the WISAP Task 4 Second Contractor Information Meeting. 1978. PNL-SA-7352, Pacific Northwest Laboratory, Richland, Washington.

Pusch, R. 1977a. Water Uptake in a Bentonite Buffer Mass--A Model Study. KBS, Hogskolan i Lulea, 1977-08-22.

Pusch, R. 1977b. Required Physical and Mechanical Properties of Buffer Masses. KBS-33.

Pusch, R. 1978a. Self-Injection of Highly Compacted Bentonite into Rock Joints. KBS Teknisk Rapport 73.

Pusch, R. 1978b. Highly Compacted Sodium Bentonite as a Buffer Substance. KBS Teknisk Rapport 74 .

Pusch, R. 1979a. Clay Particle Redistribution and Piping Phenomena in Bentonite/Quartz Buffer Material Due to High HydrauTic Gradients. KBS Technical Report 79-01. 18 pp.

Pusch, R. 1979b. Water Percolation Effects on Clay-Poor Bentonite/Quartz Buffer Material at High Hydraulic Gradients. KBS Technical Report 79-17, $11 \mathrm{pp}$.

Pusch, R. 1979c. "Highly Compacted Sodium Bentonite for Isolation RockDeposited Radioactive Waste Products." Nuclear Technology. Vol. 45, $2: 153-157$. 
Swyler, K. J., R. W. Klaffky and P. W. Levy. 1980. "Recent Studies of Radiation Damage Formation in Synthetic $\mathrm{NaCl}$ and Natural Rock Salt for Radioactive Waste Disposal Applications." C. J. M. Northrup, ed. Scientific Basis for Nuclear Waste Management. 2:553-560. Plenum Press.

Taylor, R. M., D. M. Phelan and Rothstein. 1979. Detailed Conceptual Design of a High-Temperature Glass pH Electrode for Geothermal Applications. PNL/3051, Pacific Northwest Laboratory, Richland, Washington.

Velde, B. 1977. Clays and Clay Minerals in Natural and Synthetic Systems. Elsevier, Amsterdam. 


\section{APPENDIX A}

SORPTION DATA 


\section{SORPTION DATA}

TABLE A.1. Batch Sorption of ${ }^{152} \mathrm{Eu}^{3+}$ with Different Competing Ion Concentrations at Room Temperature and $\mathrm{Ph}=5.5$ (Nowak 1980)

$\frac{\text { Sorbent }}{\text { Montmorillonite (SWy-1)(a) }}$
Hectorite (SHCa-1)(a)
Mordenite (zeolite)
Dewey Lake Redbeds (DLR)
Caliche

\begin{tabular}{|c|c|}
\hline \multicolumn{2}{|c|}{$\mathrm{K} d \mathrm{ml} / \mathrm{gm}$} \\
\hline 1 Brine $B$ & Brine B \\
\hline 960 to 990 & 100 to 500 \\
\hline 2,500 to 2,700 & 3,400 \\
\hline 24,000 to 26,000 & 11 to 13 \\
\hline 320 to 380 & 200 to 1000 \\
\hline 12 to 13 & 120 to 150 \\
\hline
\end{tabular}

(a) Reference clay material. NOTE: Initial Tracer Concentration, $\mathrm{C}_{0}=2 \times 10^{-8} \mathrm{M}$ Liquid Brine Volume $=20 \mathrm{ml}$ Batch Contact Time $=2$ weeks Sol id Sorbent Mass $=0.5 \mathrm{gm}$ $\mathrm{pH}=5.5$. 
TABLE A.2. Characterization of Reference Sorbent Materials (Nowak 1980)

SWy-1, Montmorillonite, Wyoming

Cation exchange capacity: $76 \mathrm{mdq} / 100 \mathrm{gm}$

$\mathrm{Mg}$ and $\mathrm{K}$ (minor and may be present as soluble salts)

Surface Area: $32 \mathrm{~m}^{2} / \mathrm{gm}$ by $\mathrm{N}_{2}$ BET (method of Brunauer, Emmett and Teller)

SHCa-1, Hectorite, California

Cation exchange capacity: $44 \mathrm{meq} / 100 \mathrm{gm}$

Exchangeable cations: $\mathrm{Ca}$ and $\mathrm{Na}$ (principal)

$\mathrm{Mg}$ and $\mathrm{K}$ (minor and may be present as soluble salts)

Surface area: $63 \mathrm{~m}^{2} / \mathrm{gm}$ by $\mathrm{N}_{2}$ BET

kKGa-1, Kaolinite, well crystallized, Georgia

Cation exchange capacity: $2 \mathrm{meq} / 100 \mathrm{gm}$

Exchangeable catins: not measured

Suface area: $10 \mathrm{~m}^{2} / \mathrm{gm}$ by $\mathrm{N}_{2}$ BET

TABLE A.3. Summary Results for Sorption of 238Pu(IV) on Commercial Clays, and Clay-Sand Mixtures (Nowak 1980)

\begin{tabular}{|c|c|c|c|}
\hline Sorbent & Brine & pH & $\mathrm{K}_{\mathrm{d}}, \mathrm{ml} / \mathrm{gm}$ \\
\hline Bentonite & $A$ & 6.7 & 2,300 to 3,400 \\
\hline 10 wt\% Bentonite in Sand & A & 6.7 & 490 to 540 \\
\hline 10 wt\% Hectorite in Sand & A & 6.8 & 400 to 470 \\
\hline Clinoptilolite & A & 6.7 & 1,600 to 1,800 \\
\hline Bentonite & B & 7.1 & 20,000 to 40,000 \\
\hline 10 wt\% Bentonite in Sand & B & 7.1 & 3,300 to 3,800 \\
\hline $10 \mathrm{wt} \%$ Hectorite in Sand & B & 7.5 & 860 to 1,300 \\
\hline
\end{tabular}

NOTE: Temperature: $\sim 25^{\circ} \mathrm{C}$

Tracer concentration: $3 \times 10^{-8} \mathrm{M}$

Batch contact time: 3 weeks. 
TABLE A.4. Batch Sorption of 243 Am(III) on Commercial Clays, and Clay-Sand Mixtures (Nowak 1980)

\begin{tabular}{|c|c|c|c|}
\hline Sorbent & Brine & $\mathrm{pH}$ & $\mathrm{K}_{\mathrm{d}}, \mathrm{ml} / \mathrm{gm}$ \\
\hline Bentonite & B & 7.3 & 4,100 to 14,000 \\
\hline 10 wt\% Bentonite in Sand & B & 7.3 & 9,400 to 9,500 \\
\hline 10 wt\% Hectorite in Sand & B & 7.4 & 16,000 \\
\hline Clinoptilolite & B & 7.2 & 6,900 to 16,000 \\
\hline
\end{tabular}

NOTE: Temperature: $\sim 25^{\circ} \mathrm{C}$

Tracer concentration: $5 \times 10^{-7} \mathrm{M}$

Batch contact time: 3 weeks.

TABLE A.5. Water Composition Used in Swedish KBS Studies (Neretnieks 1977)

\begin{tabular}{|c|c|c|c|}
\hline $\begin{array}{l}\text { Water } \\
\text { Type } \\
\end{array}$ & $\begin{array}{c}\mathrm{I} \\
\mathrm{mg} / 1\end{array}$ & $\begin{array}{c}\text { I I } \\
\mathrm{mg} / \mathrm{I}\end{array}$ & \\
\hline $\mathrm{Na}$ & 288 & 42 & \\
\hline K & 10 & 5 & $\mathrm{pH}=8.2$ to 8.3 \\
\hline $\mathrm{Mg}$ & 15 & 7.5 & \\
\hline $\mathrm{Ca}$ & 75 & 37.5 & \\
\hline $\mathrm{Cl}$ & 500 & 93 & \\
\hline$F$ & 1.5 & 0.75 & \\
\hline $\mathrm{SO}_{4}$ & 15 & 7.5 & \\
\hline $\mathrm{HCO}_{3}$ & 200 & 100 & \\
\hline Total & 1105 & 293 & \\
\hline
\end{tabular}


TABLE A.6. Retardation Factors $\left(K_{d}\right),(\mathrm{ml} / \mathrm{gm})$ at $20^{\circ} \mathrm{C}\left(70^{\circ} \mathrm{C}\right)$ (Neretnieks 1977)

\begin{tabular}{|c|c|c|c|c|c|c|}
\hline \multirow[b]{2}{*}{ Water Type } & \multicolumn{3}{|c|}{ Cs } & \multicolumn{3}{|c|}{ Sr } \\
\hline & $\bar{I}$ & & II & $\mathrm{I}$ & & II \\
\hline Clinoptilolite & $\begin{array}{c}2,200 \text { to } 5,200 \\
(1,500 \text { to } 2,400) \\
70^{\circ} \mathrm{C}\end{array}$ & 16,000 & to 40,000 & $\begin{array}{c}600 \text { to } 1,400 \\
(4,600 \text { to } 6,700) \\
70^{\circ} \mathrm{C}\end{array}$ & 2,300 & to 4,000 \\
\hline Chabasite & 6,800 to 11,000 & 16,000 & to 40,000 & 350 to 3,700 & 2,500 & to 50,000 \\
\hline Erionite & 6,200 to 14,000 & 11,000 & to 22,000 & 600 to 21,000 & 1,500 & to 50,000 \\
\hline Mordenite & 6,900 to 11,000 & 25,000 & to 44,000 & 180 to 5,600 & 520 & to 15,000 \\
\hline Phillipsite & 2,200 to 21,000 & 22,000 & to 34,000 & 550 to 2,400 & 3,500 & to 15,000 \\
\hline & & & & & & \\
\hline Water Type & $\mathrm{I}$ & & II & $\mathrm{I}$ & & II \\
\hline Clinoptilolite & 1,000 to 30,000 & 4,000 & to 60,000 & 0 & & -- \\
\hline Chabasite & 1,000 to 80,000 & 700 & to 110,000 & 6.4 & & 0 to 86 \\
\hline Erionite & 960 to 43,000 & 9,500 & to 110,000 & 3 to 4 & & 8 to 20 \\
\hline Mordenite & 960 to 28,000 & 1,200 & to 72,000 & -- & & 5 to 20 \\
\hline Phillipsite & 930 to 94,000 & 370 & to 120,000 & 2 & & 3 to 50 \\
\hline
\end{tabular}




\section{DISTRIBUTION}

No. of

Copies

OFFSITE

A. A. Churm

DOE Chicago Patent Group

9800 South Cass Avenue

Argonne, IL 60439

27 DOE Technical Information Center

2 Argonne National Laboratory Technical Information Services Report Section

Building 2 of 3, CE 125

9700 South Cass Avenue

Argonne, IL 60439

10 Battelle Memorial Institute

Office of Nuclear Waste

Isolation

Attn: Beverly Rawles

$505 \mathrm{King}$ Avenue

Columbus, $\mathrm{OH} 43201$

Michael J. Bell, Chief

High-Level Waste Technical Development Branch

Waste Management Division

U.S. Nuclear Regulatory Commission

Washington, DC 20555

Robert A. Berner

Associate Professor Geology \& Geophysics

Department of Geology and Geophysics

Yale University

P. 0. Box 6666

New Haven, CT 06511
No. of

Copies

John Bird

Geology Department

Cornel1 University

Ithaca, NY 14853

Albin Brandstetter

Office of Nuclear Waste Isolation

Battelle Memorial Institute

505 King Avenue

Columbus, $\mathrm{OH} 43201$

2 Brookhaven National Laboratory

Reference Section

Information Division

Upton, Long Is land, NY 11973

Harry C. Burkholder

Off ice of Nuclear Waste Isolation

Battelle Memorial Institute

$505 \mathrm{King}$ Avenue

Columbus, $\mathrm{OH} 43201$

Neville G. W. Cook

Dept. of Materials Science and Mineral Engineering

Hearst Mining Building

University of California

Berkeley, CA 94720

Carl R. Cooley

DOE Office of Nuclear Waste Management

Washington, DC 20545 
No. of

Copies

Mike Cullingford

Probablistic Analys is Staff

Nuclear Regulatory Commission

Mail Stop 3103

Washington, DC 20555

Stanley N. Davis, Hydrologist

The University of Arizona

College of Earth Sciences

6540 W. Box Canyon Drive

Tucson, AZ 85705

James 0. Duguid

Battelle Memorial Institute

Office of Nuclear Waste

Isolation

505 King Avenue

Columbus, $\mathrm{OH} 43201$

Dan Egan

Environmental Protection Agency

Office of Radiation Programs

Technology Assessment Division

M/S AW559

Washington, DC 20460

Warren Eister

Department of Energy

Division of Waste Isolation

Washington, DC , 20545

Bruce R. Erdal

Los Alamos Scientific Laboratory

CNC-11, MS -514

Los Alamos, NM 87545

Larry Fitch

Office of Licensing

Systems Integration

Basalt Waste Isolation Project

Rockwell Hanford Operations

P. 0. Box 800

Richland, WA 99352
No. of

Copies

Robert M. Garrells

Dept. of Geologic Sciences

Northwestern University

Evanston, IL 60201

Mark A. Harwell

P. 0. Box 667

Cannon Beach, OR 97110

Col in A. Heath

DOE Office of Nuclear Waste Management

Washington, DC 20545

William M. Hewitt

Office of Nuclear Waste Isolation

Battelle Memorial Institute 505 King Avenue

Columbus, $\mathrm{OH} 43201$

Peter Hofmann

Office of Nuclear Waste Isolation

Battelle Memorial Institute

505 King Avenue

Columbus, $\mathrm{OH} 43201$

Muzaffer Kehnemuyi

Office of Nuclear Waste Isolation

Battelle Memorial Institute 505 King Avenue

Columbus, $\mathrm{OH} 43201$

John F. Kircher

Office of Nuclear Waste Isolation

Battelle Memorial Institute $505 \mathrm{King}$ Avenue

Columbus, $\mathrm{OH} 43201$ 
No. of

Copies

C. Kreitler

Texas Bureau of Economic Geology University Station

P. 0 . Box $X$

Austin, TX 78712

Terry R. Lash

Director of Science and Public Policy

Keystone Center

Box 38

Keystone, CO 80435

2 Lawrence Berkeley Laboratory

Reference Library

University of California

Berkeley, CA 94720

2 Lawrence Livermore Laboratory

Reference Library

P. 0. Box 808

Livermore, CA 94550

Abraham Lerman

Department of Geological Science Lacy Hall

Northwestern University

Evanston, IL 60201

Willard L. Lindsay

Centennial Professor

Colorado State University

Fort Collins, CO 80523

Stan E. Logan

Los Alamos Technical Assoc.

P. 0. Box 410

Los Alamos, NM 87544

Tom Longo

Department of Energy

Division of Waste Isolation

Washington, DC 87544
No. of

Copies

2 Los Alamos Scientific Laboratory

Reference Library

P. 0. Box 1663

Los Alamos, NM 87544

Philip F. Low

Professor of Soil Chemistry

Department of Agronomy

Purdue University Agricultural

Experiment Station

West Lafayette, IN 47907

J. B. Martin

Asst. Director for Radioactive Waste Management Branch

NRC Division of Materials and

Fuel Cycle Facility Licensing

Washington, DC 20555

John T. McGinnis

Office of Nuclear Waste Isolation

Battelle Memorial Institute

505 King Avenue

Columbus, $\mathrm{OH} 43201$

M. Merritt

WIPP, Division 4512

Sandia Laboratories

Albuquerque, NM 87115

Don P. Moak

Office of Nuclear Waste Isolation

Battelle Memorial Institute

505 King Avenue

Columbus, $\mathrm{OH} 43201$

Martin A. Molecke

Nuclear Waste Experimental

Programs

Division 4512

Sandia Laboratories

Albuquerque, NM 87185 
No. of

Copies

2 Barry N. Naft

NUS Corporation

4 Research Place

Rockville, MD 20805

2 Jeff 0 . Neff

Department of Energy

Columbus Program Office

$505 \mathrm{King}$ Avenue

Columbus, $\mathrm{OH} 43201$

2 Neil A. Norman

Environmental Sciences

Department

Bechtel National Inc.

P. 0. Box 3965

San Francisco, CA 94105

2 Oak Ridge National Laboratory

Central Research Library

Document Reference Section

Oak Ridge, TN 37830

Frank Parker

Department of Environmental

Engineering

Vanderbilt University

Nashville, TN 37235

T. H. Pigford

University of California

Berkeley, CA 94720

George F. Pinder

Dept. of Civil Engineering

Princeton University

Princeton, NY 08540

Robert 0. Pohl

Laboratory of Atomic and

Solid State Physics

Cornell University

Ithaca, NY 14853
No. of

Copies

H. L. Ragsdale

Department of Biology

Emory University

Atlanta, GA 30322

Gilbert E. Raines

Office of Nuclear Waste Isolation

Battelle Memorial Institute

505 King Avenue

Columbus, $\mathrm{OH} 43201$

L. D. Ramspott

Lawrence Livermore National Laboratories

P. 0. Box 808--L-205

Livermore, CA 94550

W. P. Reed

Acting Manager for Nuclear Waste, OMNT

U.S. Department of Commerce

National Bureau of Standards

Washington, DC 20234

Ralph Rollins

Department of Civil Engineering

Clyde Building

Brigham Young University

Provo, UT 84602

Herbert Shaw

U.S. Department of the Interior

Geological Survey

Branch of Experimental Geochem. and Mineralogy

345 Middlefield Road

Menlow Park, CA 94025 
No. of

Copies

D. B. Shipler

Battelle Memorial Institute

Office of Nuclear Waste Isolation

$505 \mathrm{King}$ Avenue

Columbus, $\mathrm{OH} 43201$

D. R. Simpson

Lehigh University

Office of Research

Beth lehem, PA 18015

Savannah River Laboratory

Reference Library

Aiken, SC 19801

Arthur J. Soinski

Energy Resources Conservation and Development Commiss ion

1111 Howe Avenue

Sacramento, CA 95825

Howard P. Stephens

Sandia Laboratories

P. 0. Box 5800

Albuquerque, NM 87115

David B. Stewart

U.S. Geological Survey

National Center 959

Reston, VA 22092

Martin S. Tierney

Environmental Assessment

Division 4514

Sandia Laboratories

Albuquerque, NM 87115

Newe 11 J. Trask, Geologist

U.S. Department of the Interior

Geological Survey

Reston, VA 22092

Bob E. Watt

1447 45th Street

Los Alamos, NM 87544
No. of

Copies

R. E. Wilems

INTERA Environmental

Consultants, Inc.

11999 Katy Freeway, Suite 610

Houston, TX 77079

Robert Williams

Electric Power Research Inst. $3412 \mathrm{Hillview} \mathrm{Avenue}$

P. 0. Box 10412

Palo Alto, CA 94304

Paul A. Witherspoon

Earth Sciences Division

Lawrence Berkeley Laboratory

Building 90

Berkeley, CA 94720

\section{ONSITE}

5 DOE Richland Operations Office

0. J. Elgert

R. B. Goranson

H. E. Ransom

J. J. Schreiber

F. R. Standerfer

13 Rockwell Hanford Operations

R. C. Arnett

R. G. Baca

R. L. Bielefeld

D. J. Carrell

R. A. Deju

F. A. Deluca

L. R. Fitch

R. E. Gephart

L. S. Leonhart

M. J. Smith

Rockwell Document Control

Rockwell Library (2) 
No. of

Copies

99 Pacific Northwest Laboratory

L. L. Ames

E. M. Arnold

G. L. Benson

D. J. Bradley

L. A. Bray

T. D. Chikalla

M. 0. Cloninger

C. R. Cole

W. J. Deutsch

P. G. Doctor

R. H. Dove

M. G. Foley

F. N. Hodges (25)

G. H. Gee

J. H. Jarrett

C. T. Kincaid

M. R. Kreiter

J. W. Lindberg
No. of

Copies

B. K. Marshall

G. L. McVay

R. W. Nelson

R. E. Nightingale

R. D. Peters

G. M. Petrie

A. M. Platt

J. V. Robinson

R. J. Serne

J. W. Shade

D. J. Silveria

J. K. Soldat

H. H. VanTuyl

J. H. Westsik

E. J. Wheelwright (25)

J. T. Zellmer

Technical Information Library (5)

Publishing Coordination (2)(KC)

Water and Land Resources Dept

Library (10) 